\title{
Post-Translational Modifications That Drive Prostate Cancer Progression
}

\author{
Ivana Samaržija
}

check for updates

Citation: Samaržija, I. PostTranslational Modifications That Drive Prostate Cancer Progression. Biomolecules 2021, 11, 247. https:// doi.org/10.3390/biom11020247

Academic Editor: Masaaki Oyama

Received: 10 January 2021

Accepted: 6 February 2021

Published: 9 February 2021

Publisher's Note: MDPI stays neutral with regard to jurisdictional claims in published maps and institutional affiliations.

Copyright: (C) 2021 by the author. Licensee MDPI, Basel, Switzerland. This article is an open access article distributed under the terms and conditions of the Creative Commons Attribution (CC BY) license (https:/ / creativecommons.org/licenses/by/ $4.0 /)$.
Laboratory for Epigenomics, Division of Molecular Medicine, Ruđer Bošković Institute, 10000 Zagreb, Croatia; Ivana.Samarzija@irb.hr

\begin{abstract}
While a protein primary structure is determined by genetic code, its specific functional form is mostly achieved in a dynamic interplay that includes actions of many enzymes involved in post-translational modifications. This versatile repertoire is widely used by cells to direct their response to external stimuli, regulate transcription and protein localization and to keep proteostasis. Herein, post-translational modifications with evident potency to drive prostate cancer are explored. A comprehensive list of proteome-wide and single protein post-translational modifications and their involvement in phenotypic outcomes is presented. Specifically, the data on phosphorylation, glycosylation, ubiquitination, SUMOylation, acetylation, and lipidation in prostate cancer and the enzymes involved are collected. This type of knowledge is especially valuable in cases when cancer cells do not differ in the expression or mutational status of a protein, but its differential activity is regulated on the level of post-translational modifications. Since their driving roles in prostate cancer, post-translational modifications are widely studied in attempts to advance prostate cancer treatment. Current strategies that exploit the potential of post-translational modifications in prostate cancer therapy are presented.
\end{abstract}

Keywords: prostate cancer; post-translational modification; phosphorylation; glycosylation; ubiquitination; SUMOylation; acetylation; lipidation

\section{Introduction}

Prostate cancer is the second most commonly occurring cancer in men and the fifth leading cause of death worldwide [1]. Since the actions of androgens and androgen receptor (AR) are among the drivers of prostate cancer [2], one of the therapeutical approaches to treat prostate cancer is androgen deprivation therapy (ADT) and the downregulation of AR signaling, which is accomplished by various strategies [3]. Although this approach brings results in the initial phases of treatment, resistance to therapy develops in a substantial part of patients and they progress to castration-resistant prostate cancer (CRPC). Consequently, novel strategies are needed to supplement actions of ADT. Another widely studied driver of prostate cancer is the dysregulation of the PTEN/PI3K/AKT/mTOR signaling that is frequently target of epigenetic and post-translational modifications as well as genetic alterations in prostate cancer. This axis is involved in every aspect of prostate cancer biology, from cancer cell growth to survival and therapy resistance [4-6]. The Janus kinase (JAK)/signal transducer and activator of transcription (STAT) pathway that is mediating the actions of cytokines, interferons, and growth factors is also critically involved in prostate cancer growth and progression [7]. Specifically, the actions of an IL6/STAT3 axis are recognized as a major regulator of prostate cancer progression while the STAT5a/b plays a role in cell viability and growth, DNA repair, epithelial-to-mesenchymal transition (EMT), metastatic dissemination in preclinical models, and resistance to enzalutamide [7]. Other strong inducers of prostate cancer progression include EGFR family signaling pathways that are, among other downstream targets, often converging to mitogen-activated protein kinases (MAPK) to regulate prostate cancer cell behaviors [8]. Additionally, hypoxiainduced signaling has been shown to promote prostate cancer progression [9]. 
In comparison to other cancer types, prostate cancer displays lower frequency of mutations and other genetic alterations. However, frequent genetic changes in prostate cancer include formation of a TMPRSS2/ERG fusion protein, AR amplifications, PTEN deletions and p53 mutations [10]. Other frequent genetic alterations in a subgroup of prostate cancer patients are the mutations in the E3 ubiquitin ligase adapter SPOP, which is found early during prostate cancer development [10].

Proteins and pathways listed above as driving forces of prostate cancer are the subjects (or executors, such as SPOP) of post-translational modifications (PTMs) that are described in further chapters. In this publication, the data from proteome and single protein studies are presented to get an overview of documented PTMs in prostate cancer that influence largely its biology. Additionally, the possibilities of therapies that target PTMs in prostate cancer are discussed.

\section{Post-Translational Modifications}

The biological systems are characterized by extreme complexity that is sustained by concerted actions of plentitude of players. Proteins are among the main biomolecules that perform wide spectrum of diverse functions including signaling, transport, biochemical reactions, and structural support. After translation is complete, majority of proteins undergo different ranges of post-translational modifications (PTMs), chemical modifications that influence largely their activity and functional abilities. The most common PTMs include phosphorylation, glycosylation, ubiquitination, SUMOylation, acetylation, and lipidation [11]. These processes are executed and fine-tuned by thousands of enzymes whose actions are tightly regulated. Deregulations in steps of PTMs leads to pathologies and this is very well documented in different types of cancers were virtually every process in the cell and the main drivers, from tumor suppressors and oncogenes to transcription factors and signaling molecules, are influenced by PTMs [12-15]. Consequently, PTMs provide potential sites of intervention where tumor promoting events could be suppressed as a part of anticancer therapy [12,14-16].

An increasing number of proteome-wide studies of PTMs offer insight into global changes in PTMs in different experimental settings. More than 300 different types of protein PTMs have been described, but only a small proportion have been investigated at the proteome level [17]. PTMs increase the proteome size from thousands to the order of millions of possible protein forms [18], indicating the complexity of the tasks of analyzing PTMs globally. The proteome-wide approach to study PTMs is especially valuable and additive in cases where protein expression levels and mutational status do not differ between conditions that are analyzed, but the changes in the function or the activity of proteins are determined on the levels of PTMs. This paper reviews evidences on the example of prostate cancer, that the tumor driving events are detectable and dissectible by proteome-wide PTM analysis. Findings from proteome studies that encompass changes in phosphorylation, glycosylation, ubiquitination, SUMOylation, and palmitoylation in different experimental settings in prostate cancer are summarized in Table 1 and discussed further in text. The data from single protein studies are added for a complete picture on PTMs in prostate cancer to emerge. 
Table 1. Findings from proteome studies on post-translational modifications that influence prostate cancer cell fate.

\begin{tabular}{c}
\hline PTM \\
\hline $\begin{array}{c}\text { Experimental Setting } \\
\text { Comparative phosphoproteomics of } \\
\text { differentially expressed kinases between } \\
\text { the highly aggressive PC-3 and PC-3M } \\
\text { cells. }\end{array}$ \\
$\begin{array}{c}\text { (Phospho)proteomic profiling of human } \\
\text { prostate cancer (PCa)-associated } \\
\text { fibroblasts. }\end{array}$ \\
$\begin{array}{c}\text { Characterization of the ERG-regulated } \\
\text { kinome. }\end{array}$ \\
$\begin{array}{c}\text { Phosphoproteome of treatment naive and } \\
\text { metastatic CRPC tissue samples } \\
\text { integrated with genomic and } \\
\text { transcriptomic data. }\end{array}$ \\
$\begin{array}{c}\text { Analysis of global phosphoproteomic } \\
\text { changes induced by fish oil in human } \\
\text { PCa. }\end{array}$ \\
Phosphoproteomics data from mouse \\
model of PCa progression [24] integrated \\
with gene expression analysis and \\
literature mining.
\end{tabular}

\section{Phosphorylation}

Comparative phosphoproteome analysis of a PCa cell line, LNCaP, and an

LNCaP-derived androgen-independent cell line, LNCaP-AI.

Quantitative proteomic approach to compare protein phosphorylation in orthotopic xenograft tumors grown in either intact or castrated mice.

Phosphotyrosine peptide enrichment and quantitative mass spectrometry (MS) in oncogene(non-TK)-driven mouse model of PCa progression.

Proteome analysis of Aurora-A substrates using small molecule inhibitor and reverse in-gel kinase assay in PC-3 cells.

Phosphoproteomics of metastatic docetaxel-resistant PCa cell lines (DU145-Rx and PC-3-Rx).

Main Findings

Ref.

PAK2, SLK, MST4, MAP2K2, and ARAF are kinases that are potentially associated with increased migration in PC-3M cells.

PCa-associated fibroblasts-derived LOXL2 is an important mediator of intercellular communication within the prostate tumor microenvironment.

TNIK is suggested as a potential therapeutic target.

Six major signaling pathways with phosphorylation of several key residues are significantly enriched in CRPC tumors; clinically relevant information (kinase target potential based on patient-specific networks) potentially suitable for patient stratification and targeted therapies in late stage PCa is provided.

Pyruvate dehydrogenase alpha 1 is a target of omega-3 polyunsaturated fatty acids in human PCa.

A total of 125 wild type kinases implicated in human PCa metastasis were selected for screen for in vivo metastatic ability; the RAF family, MERTK, and

NTRK2 kinases drive PCa bone and visceral metastasis, and are highly expressed in human metastatic PCa tissues, potentially representing important therapeutic targets.

The phosphorylation level of THRAP3 is significantly lower in LNCaP-AI cells; nonphosphorylatable mutant form of THRAP3 and the phosphorylation-mimic form differ significantly

in protein binding repertoire; many of the differentially interacting proteins were identified as being involved in RNA splicing and processing.

Changes in phosphorylation of YAP1 and PAK2 and their elevated levels in CRPC identified; YAP2 and PAK2 regulate cell colony formation and invasion in androgen-independent cells; PAK2 influences cell proliferation and mitotic timing; pharmacologic inhibitors of PAK2 and YAP1 are able to inhibit the growth of androgen-independent PC-3 xenografts.

Elevated TK signaling (EGFR, EPHA2, JAK2, ABL1, and steroid receptor coactivator (SRC) tyrosine kinase activation) is recorded.

NuMA becomes hypo-phosphorylated in vivo upon Aurora-A inhibition; mutation of three of these phospho-sites significantly diminishes cell proliferation and increases the rate of apoptosis;

NuMA T1804A mutant mislocalizes to the cytoplasm in interphase nuclei in a punctate pattern.

Increased phosphorylation of FAK mediates chemoresistance in CRPC. 
Table 1. Cont.

\begin{tabular}{|c|c|c|c|}
\hline PTM & Experimental Setting & Main Findings & Ref. \\
\hline \multirow{6}{*}{ Glycosylation } & $\begin{array}{l}\text { Proteomics analysis to determine the } \\
\text { O-glycan profiles of PCa cells } \\
\text { metastasized to bone (PC-3), brain } \\
\text { (DU145), lymph node (LNCaP), and } \\
\text { vertebra (VCaP) in comparison to } \\
\text { immortalized RWPE-1 cells derived from } \\
\text { normal prostatic tissue. }\end{array}$ & $\begin{array}{l}\text { PCa cells exhibit an elevation of simple/short } \\
\text { O-glycans, with a reduction of complex O-glycans, } \\
\text { increased O-glycan sialylation, and decreased } \\
\text { fucosylation. Core } 1 \text { sialylation is increased in all } \\
\text { PCa cells. The expression of sialyl-3T antigen, which } \\
\text { is the product of ST3Gal-I is increased. ST3Gal-I is } \\
\text { associated with PC-3 cell proliferation, migration } \\
\text { and apoptosis. Downregulation of ST3Gal-I reduces } \\
\text { the tumor size in xenograft mouse model. }\end{array}$ & [30] \\
\hline & $\begin{array}{l}\text { Comprehensive proteomic approaches of } \\
\text { FUT8 overexpressing PCa cells. }\end{array}$ & $\begin{array}{l}\text { Upregulation of EGFR and its downstream } \\
\text { signaling; increased cell survival in } \\
\text { androgen-depleted conditions. }\end{array}$ & {$[31]$} \\
\hline & $\begin{array}{c}\text { Extracellular vesicles (EV)-derived } \\
\text { glycoproteins upon overexpression of } \\
\text { FUT8 in PCa cells. }\end{array}$ & $\begin{array}{l}\text { Reduced number of vesicles secreted by PCa cells; } \\
\text { increase in the abundance of proteins associated } \\
\text { with cell motility and PCa metastasis; altered } \\
\text { glycans on select EV-derived glycoproteins. }\end{array}$ & [32] \\
\hline & $\begin{array}{l}\text { O-GlcNAc chromatin consensus motif } \\
\text { imposed by OGT used as a bait for MS; } \\
\text { combination with MYC chromatin } \\
\text { immunoprecipitation (ChIP)-MS in PCa } \\
\text { cells. }\end{array}$ & $\begin{array}{l}\text { OGT is an essential mediator in } \\
\text { androgen-independency, which is the major } \\
\text { mechanism of PCa progression. }\end{array}$ & [33] \\
\hline & $\begin{array}{l}\text { Proteomics of androgen-dependent and } \\
\text { androgen-resistant LAPC } 4 \text { cells. }\end{array}$ & $\begin{array}{l}\text { FUT8 is significantly overexpressed in the } \\
\text { androgen-resistant LAPC4 cells; overexpression of } \\
\text { FUT8 might be responsible for the decreased PSA } \\
\text { expression in prostate cancer specimens. }\end{array}$ & [34] \\
\hline & $\begin{array}{c}\text { Cell surface Thomsen-Friedenreich }(\mathrm{TF}) \\
\text { antigen proteome profiling of metastatic } \\
\text { PCa cells. }\end{array}$ & $\begin{array}{c}\text { CD44, } \alpha 2 \text { integrin, } \beta 1 \text { integrin, CD49f, CD133, CD59, } \\
\text { EphA2, CD138, transferrin receptor and profilin } \\
\text { express TF antigen; TF antigen positive prostate } \\
\text { cancer cells form significantly more and larger } \\
\text { prostaspheres under both non-differentiating and } \\
\text { differentiating conditions and express higher levels } \\
\text { of stem cell markers. }\end{array}$ & [35] \\
\hline \multirow{3}{*}{ Ubiquitination } & $\begin{array}{l}\text { Overexpression or depletion of USP22 in } \\
\text { PCa cells and analysis of the } \\
\text { ubiquitylome. }\end{array}$ & $\begin{array}{l}\text { Depletion of USP22 sensitizes cells to genotoxic } \\
\text { insult; analysis of the USP22-sensitive ubiquitylome } \\
\text { identified the nucleotide excision repair protein, } \\
\text { XPC, as a critical mediator of the USP22-mediated } \\
\text { response to genotoxic insult. }\end{array}$ & [36] \\
\hline & $\begin{array}{l}\text { Knockdown of E6AP in DU145 cells and } \\
\text { analysis of a proteome. }\end{array}$ & $\begin{array}{l}\text { Clusterin is a novel target of E6AP; concomitant } \\
\text { knockdown of clusterin and E6AP partially restores } \\
\text { cell growth. }\end{array}$ & [37] \\
\hline & $\begin{array}{l}\text { Changes in the ubiquitin landscape } \\
\text { induced by prostate cancer-associated } \\
\text { mutations of SPOP in immortalized } \\
\text { prostate epithelial cells expressing } \\
\text { endogenous SPOP. }\end{array}$ & $\begin{array}{l}\text { DEK and TRIM24 are effector substrates consistently } \\
\text { upregulated by SPOP mutants with decreases in } \\
\text { ubiquitination and proteasomal degradation } \\
\text { resulting from heteromeric complexes of wild type } \\
\text { and mutant SPOP protein; DEK stabilization } \\
\text { promotes prostate epithelial cell invasion. }\end{array}$ & [38] \\
\hline SUMOylation & $\begin{array}{l}\text { Quantitative proteomics to identify } \\
\text { SUMOylated proteins in SUMO stably } \\
\text { transfected PC-3 cells. }\end{array}$ & $\begin{array}{l}\text { More than } 900 \text { putative target proteins of SUMO are } \\
\text { identified; mutation of newly identified SUMO } \\
\text { modification sites of USP39 further promotes the } \\
\text { proliferation-enhancing effect of USP39 on PCa cells. }\end{array}$ & [39] \\
\hline
\end{tabular}


Table 1. Cont.

\begin{tabular}{|c|c|c|c|}
\hline PTM & Experimental Setting & Main Findings & Ref. \\
\hline \multirow{4}{*}{ Palmitoylation } & $\begin{array}{l}\text { Palmitoyl-proteomic analysis of large and } \\
\text { small cancer-derived PCa EVs [40]. }\end{array}$ & $\begin{array}{l}\text { STEAP1, STEAP2, and ABCC4 are identified as } \\
\text { PCa-specific palmitoyl-proteins abundant in both EV } \\
\text { populations; their localization in EVs is reduced } \\
\text { upon inhibition of palmitoylation in the producing } \\
\text { cells. }\end{array}$ & [40] \\
\hline & $\begin{array}{l}\text { Palmitoyl proteomic analysis of breast } \\
\text { and PCa cell lines, } \pm \text { DHHC } 3 \text { ablation. }\end{array}$ & $\begin{array}{l}\text { Putative substrates include } 22-28 \\
\text { antioxidant/redox-regulatory proteins and DHHC3 } \\
\text { ablation elevates oxidative stress; DHHC3 ablation, } \\
\text { in combination with chemotherapeutic drug } \\
\text { treatment, elevates oxidative stress, with a greater } \\
\text { than additive effect, and enhances the anti-growth } \\
\text { effects of the chemotherapeutic agents; DHHC3 } \\
\text { ablation synergizes with PARP inhibitor PJ-34, to } \\
\text { decrease cell proliferation and increase oxidative } \\
\text { stress. }\end{array}$ & [41] \\
\hline & $\begin{array}{l}\text { Proteomic experiments using clickable } \\
\text { palmitate probe (Alk-C16) between three } \\
\text { individual pairs of androgen-treated and } \\
\text { non-treated LNCaP cells. }\end{array}$ & $\begin{array}{l}\text { Androgen treatment significantly increased the } \\
\text { palmitoylation level of eIF3L, which may be used as } \\
\text { a biomarker for the diagnosis of early-stage PCa. }\end{array}$ & [42] \\
\hline & $\begin{array}{l}\text { LNCaP cells metabolically-labeled with } \\
\text { Alk-C16, a palmitate probe and treated } \\
\text { with R1881, an androgen, or DMSO after } \\
\text { which palmitoylome profiling was } \\
\text { performed. }\end{array}$ & $\begin{array}{l}\text { Androgen treatment significantly increases the } \\
\text { palmitoylation level of } \alpha \text {-tubulin and Ras-related } \\
\text { protein Rab-7a (Rab7a), which are essential for cell } \\
\text { proliferation; in the supernatant of LNCaP cells, the } \\
\text { palmitoylation level of } \alpha \text {-tubulin is also increased } \\
\text { following androgen treatment, which may represent } \\
\text { a biomarker for early-stage PCa. }\end{array}$ & [43] \\
\hline
\end{tabular}

\section{Post-Translational Modifications in Prostate Cancer}

\subsection{Phosphorylation}

Phosphorylation is one of the most extensively studied and among the most frequently experimentally observed PTMs [11]. It is considered that around $40 \%$ to $60 \%$ of proteins are temporarily phosphorylated. This PTM is used as a molecular switch for protein activity, which regulates almost every aspect of cellular processes from growth, differentiation, and apoptosis to cell signaling. Phosphorylated proteins or proteins involved in phosphorylation (kinases and phosphatases) are among the main drivers of many cancers including that of prostate. Both AR and the PTEN/PI3K/AKT/mTOR axis are driven by phosphorylation, which directs the outcomes of their actions. AR is phosphorylated at 18 sites by many different enzymes, which influences its stability, nuclear localization, and transcriptional activity [44-46], which in turn regulates the prostate cancer cell fate.

Phosphatidylinositol-3 kinases (PI3Ks) are a large family of lipid kinases activated mainly by receptor tyrosine kinases. After activation, a wave of downstream signaling events takes place initiated by a synthesis of a lipid secondary messenger phosphatidylinositol 3, 4, 5 trisphosphate (PIP3) to mediate cell growth, proliferation, and apoptosis. The tumor suppressor, phosphatase and tensin homolog deleted on chromosome 10 (PTEN), negatively regulates PI3K signaling by converting PIP3 back to phosphatidylinositol 4,5 bisphosphate. PIP3 recruits phosphoinositide-dependent kinase 1 (PDK1) and AKT to the plasma membrane, where PDK1 phosphorylates AKT at Thr-308. This is further complemented by the action of mammalian target of rapamycin complex 2 (mTORC2), which phosphorylates AKT at Ser-473 for its full activation [5]. Part of this signaling axis is depicted on Figure 1 and involves phosphorylation of downstream AKT targets, such as FOXOs, GSK3, and NF- $\mathrm{kB}$. As seen on Figure 1, functional studies have revealed many kinases to be involved in prostate cancer biology. Growth factor and cytokine signaling conveyed by different receptor kinases (e.g., ErbB2 [47], FGFRs [48-53], IGF1R [54-58], 
CXCRs [59-69]) as well as plasma membrane and cytoplasm located kinases are shown to critically influence prostate cancer. As an example, MAPKs are serine/threonine kinases that link extracellular signals to downstream machinery that influences cell behaviors. Among them, MAPK1 [70-72], MAPK4 [73], and JNK [74] show the most prominent roles in regulation of prostate cancer progression. They are shown to activate multiple substrates in response to various stimuli including cytokines, growth factors, oxidative stress, ultraviolet radiation, and drugs. Another potent inducer of prostate cancer cell growth is JAK/STAT signaling axis, which additionally regulates resistance to ADT [75] as well as the immune escape of CRPC to natural killer (NK) cells in hypoxia [76], which could be exploited in immunotherapy against prostate cancer.

Prostate cancer metastasis formation is, among other proteins, influenced by EphA2 [77], steroid receptor coactivator (SRC) family tyrosine kinases [78], FAK [79,80], PKM2 [81], TGF $\beta$ [82], TNF $\alpha$ [83], and chemokine signaling at every step of the metastatic process. Specifically, CXCL12/CXCR4 signaling axis in prostate cancer bone metastasis (the main site of prostate cancer dissemination) participates in the formation of the endosteal niche, and blocking this axis compromises initial establishment of tumors in the bone microenvironment. Contrary, the expanding bone tumors are sensitive only to the members of growth factor receptor inhibition [66].

Cytoplasmic adapter proteins that become phosphorylated and activated downstream of many kinases are a link between kinases and other events of signaling cascades. Several adapter proteins (Figure 1) have been shown to influence prostate cancer biology. As an example, FRS2 $\alpha$ (FGF receptor substrate $2 \alpha$ ), is an FGF receptor-associated protein that was shown to regulate prostate development, regeneration, tumorigenesis and tumor angiogenesis [84,85]. Recently, it was shown that growth factor receptor-bound protein 10 (GRB10), has pro-proliferative function in prostate carcinoma [86], and that it sustains AR activity by interacting with PP2A [87]. 


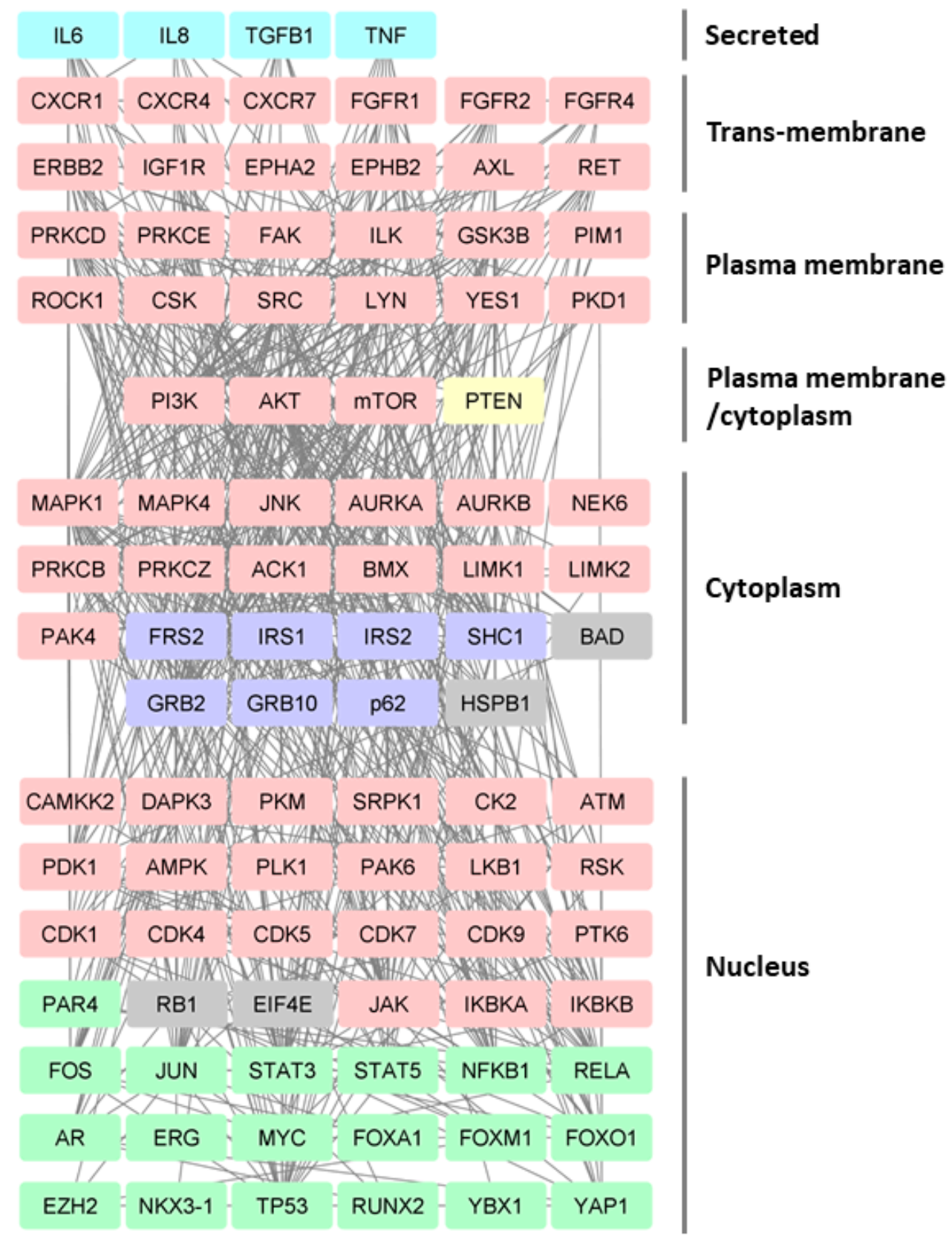

\section{Legend:}

$\begin{aligned} & \text { Cytokines, } \\ & \text { secreted ligand }\end{aligned}$ Phosphatase
$\begin{aligned} & \text { Kinases } \\ & \text { Adapter proteins }\end{aligned}$ Involved in transcription

Figure 1. Interaction network of proteins involved in or affected by phosphorylation in prostate cancer. Kinases, adapter proteins, and transcription factors are shown to visualize the network that drives prostate cancer progression. The roles of phosphatases in prostate cancer have been recently reviewed [88] and are omitted from this presentation with the exception of PTEN. Protein-protein interactions were downloaded from the STRING [89] website (experiments and databases interaction sources were used) and visualized in Cytoscape [90]. Proteins were selected based on in vitro and in vivo functional and ex vivo studies.

The examples from the previous paragraphs show how each step of the tumorigenesis/metastasis formation of prostate cancer is tightly regulated by different cascades that include phosphorylating or phosphorylated proteins. However, although prostate cancer is 
widely influenced by (de-)phosphorylating enzymes, activating tyrosine kinase mutations or amplifications are very rare in this cancer [91]. Therefore, phosphoproteome studies offer insights in their deregulations. The studies from Drake's laboratory established that MERTK and NTRK2 kinases drive prostate cancer bone and visceral metastasis [25]. Further, by comparing phosphoproteomes of treatment naive and metastatic CRPC tissue samples, Drake and colleagues revealed critical involvement of proteins from migration and invasion, nuclear receptor, PI3K/AKT/mTOR, stemness, cell cycle, and DNA repair pathways. Moreover, they suggest possible stratification of patients that could benefit from personalized therapy based on their data [22], a strategy that is described in more detail in Chapter 4. Additional proteome-wide studies listed in Table 1 investigated protein phosphorylation in orthotopic xenograft tumors grown in either intact or castrated mice and suggested that YAP1 and PAK2 kinases are involved in androgen-independent cell growth [27]. Another study from a mouse model showed elevated kinase signaling including EGFR, EPHA2, JAK2, ABL1, and SRC tyrosine kinase activation in prostate tumors [24]. Taken together, studies that investigate the roles of single proteins, as well as phosphoproteome studies, complement each other for a complete picture on the deregulation of phosphorylation in prostate cancer and its driving role in prostate cancer biology.

\subsection{Glycosylation}

Glycosylation is the attachment of a carbohydrate (glycan) to functional groups of amino acids. Two main types of glycosylation are recognized: N-glycosylation, when glycans are added to the amide group of an asparagine (Asn) residue in the endoplasmic reticulum and O-glycosylation, when they are added to the hydroxyl oxygen of serine/threonine residues (Ser/Thr) in the Golgi apparatus. Hundreds of enzymes are involved in glycosylation and, unlike other PTMs, attached glycans are extremely diverse and add significantly to the complexity of the final protein structure. Glycome, or the entire complement of sugars, exceeds the complexity of the proteome by the orders of magnitude and nearly every protein rose after the appearance of multicellular life is composed of both polypeptide and glycan parts [92]. Glycosylation is the most common PTM in cells [11] and it is involved in cell adhesion and metastasis, transmitting signals across plasma membrane, and immune modulation [93]. The expression of glyco-genes is mainly regulated on the levels of gene polymorphisms or stable epigenetic regulation [94] that is often dysregulated in cancer [95].

In prostate cancer, glycosylation and the enzymes involved play central roles in tumor progression as shown in Table 2 and reviewed recently $[96,97]$. Glyco-genes that participate in the formation of both $\mathrm{O}$ - and $\mathrm{N}$-linked glycans are deregulated in prostate cancer leading to effects on every aspect of cellular processes and behaviors, from cell proliferation, migration, apoptosis, and viability to in vivo tumor growth and metastasis formation (Table 2). Sialylation, or the addition of sialic acid residues as the terminal monosaccharide, is a process that is disturbed in cancers $[93,98]$. Sialylated blood group antigen Sialyl Lewis X (SLeX) influences prostate cancer progression through various mechanisms as well as the cancer-associated sialyl-Tn glycan (sTn), which affects prostate cancer cell adhesion and whose expression is shown to be regulated by AR [99]. Fucosylation is the addition of a fucose to a glycan, as either a terminal glycan or the addition to the core structure. As seen on Table 2, fucosylation is dysregulated in prostate cancer progression and participates in the development of castrate resistance. The addition of O-GlcNAc to proteins (O-GlcNAcylation) is catalyzed by O-GlcNAc transferase (OGT) whose substrate, UDP-GlcNAc, is synthesized in the hexosamine biosynthetic pathway (HBP). Inhibition of the HBP was also shown to promote CRPC [100]. OGT was shown to be an essential mediator in androgen-independency also in a glycoproteomic approach where O-GlcNAc chromatin consensus motif imposed by OGT was used as a bait for MS and complemented with MYC ChIP-MS in PCa cells [33]. In this way, it was shown that high OGT activity is essential for proliferation of prostate cancer cell that is driven by MYC. The glycoproteomic 
approach to prostate cancer yielded several other publications (Table 1) that show the diversity of processes in prostate cancer that implicate glycosylation.

Table 2. Involvement of glycosylation in prostate cancer biology. The step of glycosylation is stated on the top of each rectangle and examples are schematically depicted. The prostate cancer processes affected are listed on the bottom of rectangles.

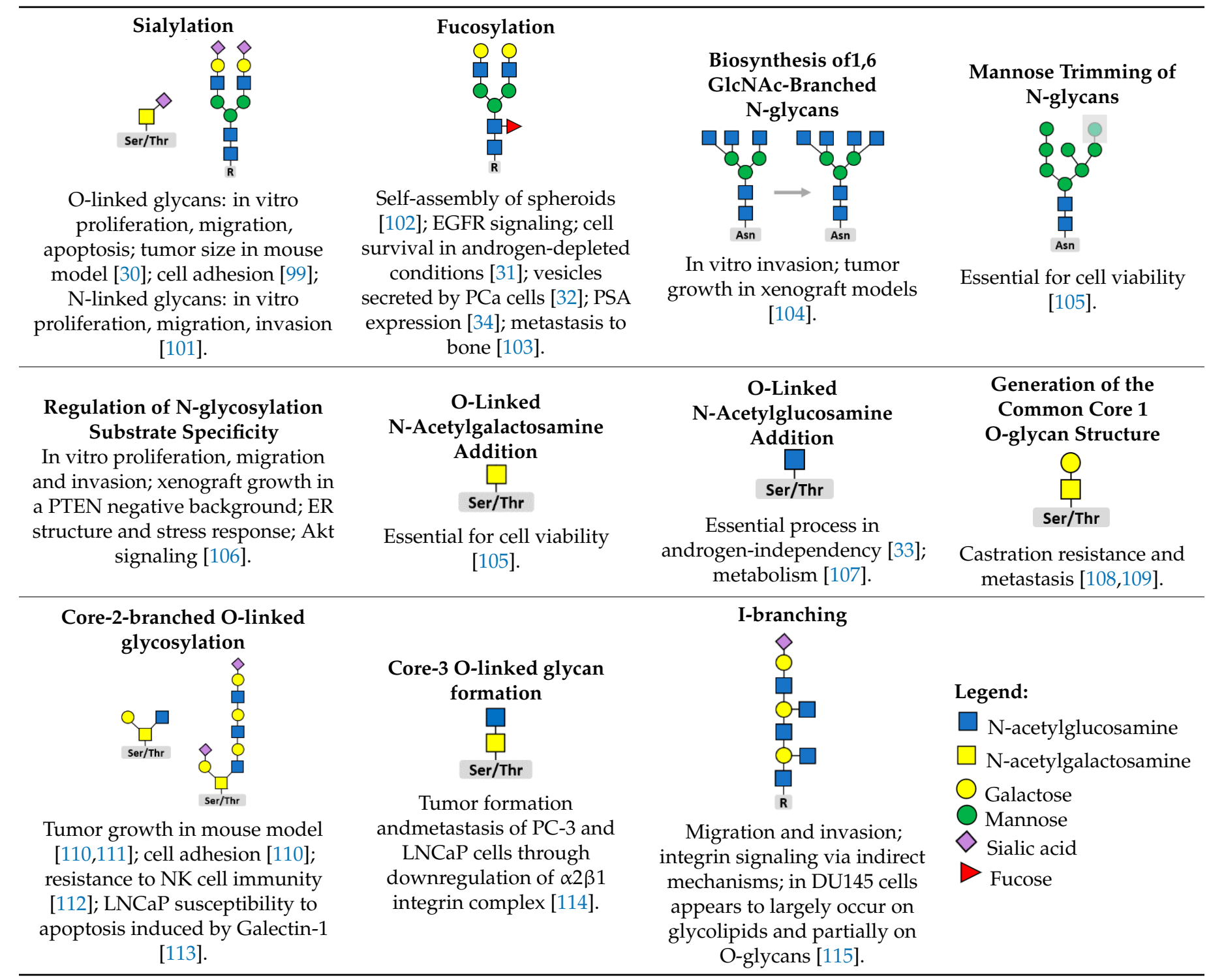

Besides the steps of glycosylation processes that are dysregulated in prostate cancer, and that affect multiple proteins globally, single glycosylated proteins or the proteins that bind glycans have been implicated in prostate cancer. Proteoglycans are proteins that are extensively glycosylated. Among them, versican, decorin, biglycan, lumican, and syndecan1 were shown to influence prostate cancer cell survival and metastasis [96,116]. Galectins are glycan binding proteins widely studied in the field of prostate cancer research [117] and, among them, galectin-3 was linked to tumor progression [118] and bone remodeling of the bone metastasis niche [119].

In addition to playing driving roles in prostate cancer, another important feature that glycosylation brings to the field of prostate cancer research is the potential to serve as a source of biomarkers of disease progression and severity. One of the central issues in prostate cancer management is to distinguish indolent and aggressive prostate cancer to tailor the treatments accordingly. Current methods that are available do not offer satisfying 
solution to this issue. Therefore, glycans were suggested to be considered as a supplement to the current tools to diagnose prostate cancer rapidly, and to precisely determine tumor aggressiveness and prognosis [96]. As an example, sialylation of the prostate-specific antigen (PSA), a serine protease secreted by prostate that liquefies semen, has shown the robust prediction power to diagnose aggressive prostate cancer $[120,121]$.

\subsection{Ubiquitination}

Ubiquitination (or ubiquitylation) is a covalent attachment of a ubiquitin, a small protein composed of 76 amino acids $(8.5 \mathrm{kDa})$ with highly conserved primary sequence to lysines of a substrate protein via an isopeptide bond. Depending on the number of ubiquitin units attached, proteins can be monoubiquitinated (addition of a single ubiquitin molecule) or polyubiquitinated (sequential addition of more ubiquitin molecules to preceding ubiquitins). The polyubiquitin chains are named, according to which of the seven lysines $(\mathrm{K})$ within ubiquitin are used to link the chains. Ubiquitination is a process that controls protein abundance, function, and trafficking. Usually, K48-linked chains lead to degradation of a substrate, while K63-linked chains can alter the protein's activity, interaction, or localization. Furthermore, monoubiquitination mainly plays a role in protein trafficking while polyubiquitination, in addition to protein trafficking, contributes to degradation. Proteins modified by ubiquitin addition are recognized by the proteasome, a cylinder-shaped multi-protein cellular structure located in the cytoplasm and the cell nucleus, which cleaves and degrades or modulates the proteins. This system is known as the ubiquitin-proteasome system (UPS) and its precise control ensures that unnecessary, damaged, misfolded, and potentially harmful proteins are removed. Virtually every process in the cell, from the cell cycle to cell adhesion, migration, invasion, apoptosis, differentiation, angiogenesis, and tumor growth, antigen processing, cytokine signaling, transcription, and DNA damage response is regulated by the UPS $[122,123]$. Many proteins are involved in the processes of ubiquitination, which is divided in three steps. In a first step, ubiquitin is activated by the ubiquitin-activating enzyme (E1) via using ATP. Subsequently, it becomes transferred to the ubiquitin-conjugating enzyme (E2) and recruited into the E3 ligase, which binds the substrate protein and targets it for proteasome degradation. It is widely accepted that E3 ligases direct the specificity of the complex towards the substrate, which is ensured by the increase in the number of enzymes from E1 to E3. While there are only two E1 and 38 E2 enzymes, there are more than 600 human E3 ubiquitin ligases, which are classified according to the protein sequence homology into the largest Really Interesting New Gene (RING) finger family with more than 600 predicted members and the HECT (Homologous to the E6-AP Carboxyl Terminus) family, with approximately 30 members in the human genome [124]. There are also less common Ring-Between-Ring (RBR) family [125] with 12 members as well as the U-box type E3 ligases, which create an E2 binding surface that resembles a RING finger [126]. These enzyme families differ also by a mechanism of ubiquitination; while RING finger or U-box E3 ligases act as a scaffold, HECT, and RBR type E3 ligases form transient thioester linkages with ubiquitin before transferring it to the protein substrate. Furthermore, RING type E3 ligases can be classified as single or multisubunit E3 ubiquitin ligases. Example of a multisubunit E3 ubiquitin ligase are the SCF cullin-RING ligases (CRLs). CRLs are the major group of RING-type E3 ligases and SCFs are SKP1-CUL1-F-box protein E3 ligases with 69 different complexes found in humans. U-box type ubiquitin ligases are also classified as E4 ubiquitin ligases, a new class of ubiquitination enzymes [127].

The concerted action of ubiquitination enzymes that leads to control of protein abundance and function in a cell is supplemented by the actions of deubiquitinases (DUBs), which remove ubiquitin chains from a substrate and protect it from degradation. This type of interplay between ubiquitinating and de-ubiquitinating enzymes is required to keep the cellular homeostasis [128]. It is estimated that the human genome encodes approximately 100 DUBs [129]. 
Considering the involvement of ubiquitination in many cellular processes, it is not surprising that the failure to keep it tightly regulated contributes to many pathologies including prostate cancer. The most prominent role among the enzymes involved in ubiquitination in prostate cancer has been described for speckle-type poxvirus and zinc finger (POZ) protein (SPOP) that functions as a substrate adaptor of a CRL3. This protein is altered genetically or through changes in expression in a number of cancers [130]. For prostate cancer, the number of cases with genetic alterations ranges from $4.4 \%$ to $28.6 \%$ of the cases studied and the number of the cases with downregulation ranges from 25.2 to $93.5 \%$ [130]. SPOP mutations are often located in the substrate-binding domain suggesting its biological role. While the role of SPOP protein differs depending on the tumor type, in prostate cancer, SPOP seems to function as a tumor suppressor and its targets for degradation, among others, include AR, ERG, steroid receptor coactivator 3 (SRC3), BRD4, MYC, and TRIM24 [130,131]. The essential role of SPOP in prostate carcinogenesis has been confirmed in different mouse models where SPOP mutations activate the PI3K/mTOR pathway and promote carcinogenesis [132]. Ubiquitylome analysis of a landscape induced by prostate cancerassociated mutations of SPOP in immortalized prostate epithelial cells expressing endogenous SPOP revealed DEK and TRIM24 as substrates consistently upregulated by SPOP mutants and with decreases in ubiquitination and proteasomal degradation (Table 1) [38]. Of these, DEK stabilization was shown to promote prostate epithelial cell invasion [38]. Other proteome studies revealed clusterin as a novel target of E6AP with roles in cell growth [37] and XPC, as a critical mediator of the USP22-mediated response to genotoxic insult [36] (Table 1).

While the roles of DUBs in prostate cancer have been recently reviewed [129], here, in Table 3, the summary on the roles of E3 ligases and the processes affected by their actions are presented. The target proteins of $\mathrm{E} 3$ ligases in prostate cancer, among others, are the driving proteins, such as AR, ERG, PTEN, cell-cycle progression proteins, and other transcription factors and signaling molecules (Table 3). According to the current knowledge, AR is ubiquitinated by the actions of RNF6, MDM2, CHIP, and SPOP ligases/ligase subunits, which regulate its stability, transcriptional activity, recruitment of co-activators, chromatin retention, and degradation (reviewed in $[133,134]$ ) (Table 3). In addition, the actions of BMI1 affect MDM2-mediated AR protein degradation [135]. SIAH2, an E3 RING finger ubiquitin ligase that influences formation of neuroendocrine phenotype and neuroendocrine prostate tumors through its actions on HIF-1 $\alpha$ and FOXA2 [136], is also involved in AR ubiquitination to regulate its transcriptional activity by targeting for degradation a select pool of NCOR1-bound transcriptionally-inactive AR on a group of gene promoters/enhancers [137]. In this way, the subsequent recruitment of AR/coactivator complexes to increase the transcriptional output of selective AR target genes is potentiated. It is interesting to note that in the same publication, the authors did not observe changes in the global levels of AR, emphasizing the subtle roles of SIAH2 in the control of a specific pool of ARs. In a recent work, Vatapalli et al. [138] have shown that upregulation of MYCregulated E3 ubiquitin ligases HECTD4 and MYCBP2 promotes AR and MYC degradation that leads to repression of MYC in a negative feed forward manner and regulation of the tumorigenicity of AR-positive prostate cancer cells. Among the most prominent E3 ligases that influence prostate cancer is SKP2, an F-box protein, and a crucial component of the SCF type of E3 ubiquitin ligase complexes. SKP2 has been shown to also affect AR ubiquitination [139], but additionally its targets in prostate cancer include EZH2, p27, JARID1B, DAB2IP, AKT, BRCA2, ATF4, p27, p21, and Twist to regulate various cellular processes (Table 3 ). 
Table 3. Ubiquitin E3 ligases, their target proteins, and processes they influence in prostate cancer. Signaling pathways regulated by deubiquitinases in prostate cancer have been recently reviewed [129], as well as the roles of the SPOP protein $[130,131]$, substrate adaptor of a CRL3 that is frequently mutated in prostate cancer.

\begin{tabular}{|c|c|c|c|}
\hline $\begin{array}{l}\text { (Component of) } \\
\text { E3 Ligase }\end{array}$ & Description & $\begin{array}{l}\text { Affected Protein(s) } \\
\text { and/or Signaling } \\
\text { Pathways }\end{array}$ & Effects on Processes \\
\hline \multicolumn{4}{|l|}{ RING type } \\
\hline AMFR & $\begin{array}{l}\text { RING-type E3 ubiquitin transferase, } \\
\text { component of a complex that } \\
\text { participates in the final step of } \\
\text { ER-associated degradation }\end{array}$ & 3ßHSD1 [140] & $\begin{array}{l}\text { DHT synthesis necessary to activate the } \\
\text { AR [140] }\end{array}$ \\
\hline $\mathrm{APC} / \mathrm{C}$ & $\begin{array}{l}\text { Multi-subunit cullin-RING E3 } \\
\text { ubiquitin ligase that regulates } \\
\text { progression through the metaphase to } \\
\text { anaphase of the cell cycle }\end{array}$ & $\begin{array}{c}\text { Cyclin A2, Geminin, } \\
\text { PLK1, Aurora A, and } \\
\text { CDC20 [141]; SKP2 [142] }\end{array}$ & $\begin{array}{c}\text { PTEN loss but not phosphatase } \\
\text { inactivation results in hypersensitivity } \\
\text { to pharmacological inhibition of } \\
\text { APC-CDH1 targets PLK1 and Aurora A } \\
\text { [141]; cell cycle [142] }\end{array}$ \\
\hline
\end{tabular}

\begin{tabular}{|c|c|c|c|}
\hline BIRC6 & $\begin{array}{l}\text { Consists of a BIR and a } \\
\text { ubiquitin-conjugating (UBC) domain } \\
\text { with chimeric E2/E3 ubiquitin ligase } \\
\text { activity; through its BIR domain } \\
\text { binds to active caspases; through its } \\
\text { UBC domain, facilitates proteasomal } \\
\text { degradation of pro-apoptotic proteins }\end{array}$ & $\begin{array}{l}\text { GPCR and matrisome } \\
\text { signaling; prosurvival } \\
\text { genes [143] }\end{array}$ & $\begin{array}{c}\text { Implicated in advanced, Enzalutamide } \\
\text { (Enz)-resistant PCa [143]; role in PCa } \\
\text { progression and treatment resistance } \\
{[144]}\end{array}$ \\
\hline BMI1 & $\begin{array}{l}\text { Contains a RING motif; it does not } \\
\text { have E3 ubiquitin ligase activities; } \\
\text { forms a complex with RING1B to } \\
\text { ubiquitinate H2A-K119 and repress } \\
\text { the expression levels of polycomb } \\
\text { repressive complex } 1 \text { (PRC1) targets }\end{array}$ & AR [135] & $\begin{array}{l}\text { PRC1-independent role in } \\
\text { MDM2-mediated AR protein } \\
\text { degradation; tumor growth of } \\
\text { xenografts that have developed } \\
\text { resistance to surgical castration and } \\
\text { Enz treatment [135] }\end{array}$ \\
\hline CAND1 & $\begin{array}{l}\text { F-box protein exchange factor; key } \\
\text { assembly factor of SCF E3 ubiquitin } \\
\text { ligase complexes }\end{array}$ & p21 [145]; PLK4 [146] & $\begin{array}{l}\text { In vitro cell viability, proliferation, } \\
\text { apoptosis [145]; centriole } \\
\text { overduplication [146] }\end{array}$ \\
\hline c-CBL & RING domain E3 ligase & EGFR [147] & $\begin{array}{c}\text { EGFR/Erk1/2 signaling-mediated PCa } \\
\text { [147] }\end{array}$ \\
\hline COP1 & RING-type E3 ubiquitin transferase & $\begin{array}{c}\text { STAT3 [148]; ETS } \\
\text { transcription factors } \\
{[149]}\end{array}$ & $\begin{array}{c}\text { Tumorigenesis; proliferation and cancer } \\
\text { stem-like properties in prostate } \\
\text { epithelial cells }[148,149]\end{array}$ \\
\hline CRL4/Cdt2 & $\begin{array}{c}\text { Proliferating cell nuclear antigen } \\
\text { (PCNA)-dependent E3 ubiquitin } \\
\text { ligase }\end{array}$ & WHSC1 [150] & $\begin{array}{c}\text { Interaction with key intracellular } \\
\text { signaling molecules, AKT, RICTOR, } \\
\text { and Rac1, to drive PCa metastasis [150] }\end{array}$ \\
\hline CUL3 & $\begin{array}{c}\text { Cullin-RING-based E3 ubiquitin } \\
\text { ligase }\end{array}$ & & $\begin{array}{l}\text { Mutated in a subset of PCa indicating } \\
\text { possible driving roles [151] }\end{array}$ \\
\hline CUL4A & $\begin{array}{l}\text { Cullin family of ubiquitin ligase } \\
\text { proteins }\end{array}$ & AR [152] & AR protein homeostasis [152] \\
\hline CUL4B & $\begin{array}{l}\text { Scaffold protein that assembles the } \\
\text { Cullin4B-RING E3 ligase complex }\end{array}$ & BMI1 [153], c-MYC [154] & $\begin{array}{c}\text { Cancer stem-like traits of PCa cells } \\
\text { [153]; PCa progression [154] }\end{array}$ \\
\hline FBXL2 & $\begin{array}{l}\text { F-box protein; the receptor subunit of } \\
\text { one of } 69 \text { human SCF ubiquitin ligase } \\
\text { complexes }\end{array}$ & IP3R3 [155] & $\begin{array}{l}\text { Ca2+-mediated apoptosis and tumor } \\
\text { growth [155] }\end{array}$ \\
\hline FBXL4 & $\begin{array}{c}\text { Member of the F-box protein family; } \\
\text { part of a modular E3 SCF ubiquitin } \\
\text { ligase complexes }\end{array}$ & $\begin{array}{l}\text { Potentially ERLEC1 } \\
\text { [156] }\end{array}$ & PCa progression and metastasis [156] \\
\hline
\end{tabular}


Table 3. Cont.

\begin{tabular}{|c|c|c|c|}
\hline $\begin{array}{l}\text { (Component of) } \\
\text { E3 Ligase }\end{array}$ & Description & $\begin{array}{l}\text { Affected Protein(s) } \\
\text { and/or Signaling } \\
\text { Pathways }\end{array}$ & Effects on Processes \\
\hline FBXL7 & $\begin{array}{l}\text { F-box protein that functions as } \\
\text { substrate receptor for SCF }\end{array}$ & c-SRC [157] & $\begin{array}{l}\text { Epithelial-to-mesenchymal transition } \\
\text { (EMT) and metastasis [157] }\end{array}$ \\
\hline FBXO45 & $\begin{array}{l}\text { Substrate-specific adaptor subunit of } \\
\text { SCF E3 ubiquitin ligase complex }\end{array}$ & PAR4 $[158,159]$ & $\begin{array}{l}\text { Cell survival [158,159]; therapy } \\
\text { resistance [159] }\end{array}$ \\
\hline FBXW7 & $\begin{array}{l}\text { F-box and WD repeat domain } \\
\text { containing } 7\end{array}$ & AURKA [160] & $\begin{array}{l}\text { Pathogenesis of prostatic small cell } \\
\text { neuroendocrine carcinoma [160] }\end{array}$ \\
\hline FBW7 & $\begin{array}{l}\text { F-box protein; a substrate receptor for } \\
\text { SCF-type E3 ligase }\end{array}$ & $\begin{array}{l}\text { Dual phosphorylated } \\
\text { ERG [161] }\end{array}$ & Driving of prostate oncogenesis [161] \\
\hline KLHL20 & $\begin{array}{l}\text { Substrate-binding subunit of Cullin3 } \\
\text { ligase }\end{array}$ & PML, HIF-1 $\alpha[162]$ & PCa progression [162] \\
\hline MARCH5 & RING-finger E3 ligase & MCL1 [163] & $\begin{array}{c}\text { Apoptosis in response to a BH3 } \\
\text { mimetic agent targeting BCLXL [163] }\end{array}$ \\
\hline MDM2 & $\begin{array}{c}\text { The RING domain E3 ubiquitin ligase; } \\
\text { key regulator of p53 tumor } \\
\text { suppressor protein activity and } \\
\text { stability }\end{array}$ & $\begin{array}{c}\text { AR [164,165]; p53 } \\
\text { [166,167]; E2F1 [168]; } \\
\text { AR-v7 [169]; E-cadherin } \\
\text { [170]; activation of p53 } \\
\text { and destabilization of } \\
\text { AR by combinatorial } \\
\text { inhibition of MDM2 and } \\
\text { MDMX [171] }\end{array}$ & $\begin{array}{l}\text { Phosphorylation-dependent } \\
\text { ubiquitination and degradation of AR } \\
\text { by AKT [165]; stem cell integrity [164]; } \\
\text { survival and proliferation of } \\
\text { genomically unstable tumor cells [167]; } \\
\text { prolongs the half-life of the E2F1 } \\
\text { protein by inhibiting its ubiquitination } \\
\text { (MDM2 displaces SCFSKP2); influences } \\
\text { cell proliferation [168] }\end{array}$ \\
\hline MYCBP2 & $\begin{array}{c}\text { Atypical E3 ubiquitin-protein ligase, } \\
\text { which mediates ubiquitination of } \\
\text { threonine and serine, instead of lysine } \\
\text { residues }\end{array}$ & AR, MYC [138] & $\begin{array}{c}\text { Tumorigenicity of AR-positive PCa } \\
\text { cells [138] }\end{array}$ \\
\hline MYLIP & $\begin{array}{l}\text { E3 ubiquitin-protein ligase whose } \\
\text { activity depends on E2 enzymes of } \\
\text { the UBE2D family }\end{array}$ & AR [172] & AR activity [172] \\
\hline PIRH2 & $\begin{array}{l}\text { Ring finger protein with ubiquitin } \\
\text { ligase activity }\end{array}$ & $\begin{array}{l}\text { Epsilon-COP [173]; } \\
\text { HDAC1 [174] }\end{array}$ & $\begin{array}{c}\text { Regulation of the secretion of PSA } \\
\text { [173]; AR signaling [174] }\end{array}$ \\
\hline pVHL & $\begin{array}{l}\text { Substrate recognition subunit of the } \\
\text { VHL-Elongin B/C E3 ligase complex } \\
\text { that targets the HIF-1/2 for } \\
\text { proteasomal degradation under } \\
\text { normoxia conditions }\end{array}$ & $\begin{array}{c}\text { AR (enhanced AR } \\
\text { de-ubiquitination } \\
\text { instead of inducing AR } \\
\text { ubiquitination) [175]; } \\
\text { HIF-1 } \alpha \text { [176] }\end{array}$ & $\begin{array}{c}\text { Suppression of AR activity [175]; HIF-1 } \\
\text { hypoxic response [176] }\end{array}$ \\
\hline RNF2 & $\begin{array}{l}\text { Also known as RING1b or RING2; } \\
\text { catalytic subunit of PRC1 }\end{array}$ & TXNIP [177]; CCL2 [178] & $\begin{array}{l}\text { Cell cycle arrest and apoptosis [177]; } \\
\text { metastasis in mice inoculated } \\
\text { intracardially with PC-3M cells [178] }\end{array}$ \\
\hline RNF6 & RING finger-type E3 ligase & $\begin{array}{c}\text { Poly- and } \\
\text { mono-ubiquitination of } \\
\text { AR [179] }\end{array}$ & $\begin{array}{l}\text { Promotes AR transcriptional activity } \\
\text { and specificity [179] }\end{array}$ \\
\hline RNF7 & $\begin{array}{l}\text { RING component of CRL } \\
\text { (Cullin-RING ligase) }\end{array}$ & $\begin{array}{l}\text { PHLPP1 and DEPTOR } \\
\text { (PI3K/AKT/mTOR axis) } \\
\text { [180]; p21, p27, NOXA; } \\
\text { ERK1/2 signaling [181] }\end{array}$ & $\begin{array}{l}\text { Proliferation in monolayer and soft } \\
\text { agar; clonogenic survival; migration } \\
\text { [180]; PCa tumorigenesis [181] }\end{array}$ \\
\hline RNF11 & RING finger-type E3 ligase & ErbB2 and EGFR [182] & Growth arrest [182] \\
\hline
\end{tabular}


Table 3. Cont.

\begin{tabular}{|c|c|c|c|}
\hline $\begin{array}{l}\text { (Component of) } \\
\text { E3 Ligase }\end{array}$ & Description & $\begin{array}{l}\text { Affected Protein(s) } \\
\text { and/or Signaling } \\
\text { Pathways }\end{array}$ & Effects on Processes \\
\hline RNF20 and RNF40 & Histone H2B ubiquitin E3 ligases & $\begin{array}{l}\text { AR, several cell cycle } \\
\text { promoters [183] }\end{array}$ & $\begin{array}{c}\text { Proliferation (due to changed } \\
\text { expression of several cell cycle } \\
\text { promoters) and modulation of AR } \\
\text { transcriptional activity in intact cells } \\
\text { [183] }\end{array}$ \\
\hline RNF41 & Ring Finger Protein 41, E3 ligase & ErbB3 [184] & AR-independent proliferation [184] \\
\hline RNF126 & $\begin{array}{l}\text { E3 ligase that contributes to } \\
\text { BAG6-mediated quality control }\end{array}$ & p21 [185] & Proliferation [185] \\
\hline SIAH2 & $\begin{array}{l}\text { E3 RING finger ubiquitin ligase; } \\
\text { member of the seven in absentia } \\
\text { homolog (SIAH) family }\end{array}$ & $\begin{array}{c}\text { EAF2 [186]; AR [137]; } \\
\text { AR-V7 [187]; HIF-1 } \alpha \text { and } \\
\text { FOXA2 [136]; } \\
\text { Wnt/ } \beta \text {-catenin signaling } \\
\text { [188] }\end{array}$ & $\begin{array}{l}\text { Apoptosis [186]; lipid metabolism, cell } \\
\text { motility, proliferation, cell growth } \\
\text { under androgen-deprivation condition } \\
\text { in vitro and in vivo, PCa regression } \\
\text { upon castration [137]; } \\
\text { castration-resistance in PCa therapy } \\
\text { [187]; formation of neuroendocrine } \\
\text { phenotype and neuroendocrine } \\
\text { prostate tumors [136]; inducing and } \\
\text { maintaining PCa cells dormancy in } \\
\text { bone [188]; death receptor-mediated } \\
\text { apoptosis [189] }\end{array}$ \\
\hline SKP2 & $\begin{array}{l}\text { F-box protein; crucial component of } \\
\text { the SCF (Skp1-Cullin1-F-box) type of } \\
\text { E3 ubiquitin ligase complexes }\end{array}$ & $\begin{array}{c}\text { EZH2 [190]; p27 } \\
\text { [191-193]; JARID1B } \\
\text { [194]; DAB2IP [195]; } \\
\text { AKT [196]; BRCA2 [197]; } \\
\text { ATF4, p27, p21 [198]; } \\
\text { Twist [199]; AR [139]; } \\
\text { IDH1/2 [200]; FOXO3 } \\
\text { [201]; E-cadherin [202] }\end{array}$ & $\begin{array}{l}\text { TRAF6-mediated ubiquitination of } \\
\text { EZH2; progression of PCa and CRPC } \\
\text { through upregulation and activation of } \\
\text { progenitor genes, as well as AR-target } \\
\text { genes [190]; paclitaxel resistance [191]; } \\
\text { tumorigenesis [192-196]; proliferation, } \\
\text { survival, glucose uptake [196]; } \\
\text { homologous recombination and } \\
\text { sensitivity to the PARP inhibitor } \\
\text { rucaparib [197]; } \\
\text { oncogenic-stress-driven senescence } \\
\text { [198]; progression and stem cell } \\
\text { features of CRPC [199]; cell } \\
\text { cycle-dependent metabolic oscillation } \\
\text { between glycolysis and TCA cycle } \\
\text { [200]; cell migration [202]; high } \\
\text { expression is associated with a } \\
\text { mesenchymal phenotype and increased } \\
\text { tumorigenic potential [203] }\end{array}$ \\
\hline SOCS2 & $\begin{array}{l}\text { Probable substrate recognition } \\
\text { component of a SCF-like ECS } \\
\text { (Elongin BC-CUL2/5-SOCS-box } \\
\text { protein) E3 ubiquitin ligase complex }\end{array}$ & $\begin{array}{l}\text { FLT3 and JAK2 [204]; } \\
\text { NDR1 stability; NF- } \mathrm{BB} \\
\text { transactivation [205] }\end{array}$ & $\begin{array}{c}\text { Metastasis formation [204]; } \\
\text { SOCS2-deficiency leads to } \\
\text { hyper-activation of NF- } \mathrm{kB} \text { and } \\
\text { downstream pathological implications } \\
\text { [205] }\end{array}$ \\
\hline TOPORS & RING domain containing E3 ligase & NKX3.1 [206] & Tumor progression [206] \\
\hline TRAF4 & RING domain E3 ubiquitin ligase & TrkA [207] & Metastasis formation [207] \\
\hline
\end{tabular}


Table 3. Cont.

\section{(Component of) E3 Ligase}

Description

\section{Affected Protein(s) and/or Signaling Pathways}

\section{Effects on Processes}

PI3K/AKT signaling; migration [208]; tumor-promoting effects of TGF $\beta$ type I

p85a [208]; TGF $\beta$ type I receptor [209,210]; PS1

TRAF6

RING domain E3 ubiquitin ligase
[196]; TAK1 [212]; EZH2 [190] receptor [209,210]; activation of mTOR; regulation of autophagy and cell proliferation [211]; proliferation, survival, glucose uptake, in vivo tumor growth [196]; activation of NF-kB signaling downstream of several receptors [212]

\begin{tabular}{|c|c|c|}
\hline TRIM11 & $\begin{array}{l}\text { E3 ubiquitin-protein ligase; the TRIM } \\
\text { motif contains a RING domain }\end{array}$ & \\
\hline TRIM16 & $\begin{array}{l}\text { It lacks a RING domain found in } \\
\text { other TRIM proteins, but can } \\
\text { dimerize with other TRIM proteins } \\
\text { and has E3 ubiquitin ligase activity }\end{array}$ & $\begin{array}{l}\text { SNAIL signaling } \\
\text { pathway [214] }\end{array}$ \\
\hline TRIM25 & RING domain E3 ubiquitin ligase & ERG [215]; G3BP2 [216] \\
\hline$\beta-\operatorname{TrCP}$ & $\begin{array}{l}\text { Substrate recognition subunit for the } \\
\text { SCF } \beta \text {-TrCP E3 ligases }\end{array}$ & $\begin{array}{c}\text { HIF-1 } \alpha \text { [217], Twist } \\
\text { [199]; CHD1 [218]; } \\
\text { MTSS1 [219]; REST [220]; } \\
\delta \text {-catenin [221]; AhR } \\
\text { [222]; Gli2 [223] }\end{array}$ \\
\hline
\end{tabular}

UHRF1 Ubiquitin Like with PHD And Ring Finger Domains 1; E3 ubiquitin ligase
Cell proliferation in vitro and the progression of PCa [213]

Progression of prostate tumors [214]

Driving of prostate carcinogenesis [215]; cell growth and survival by modulating p53 signals [216]

Progression and stem cell features of CRPC [199]; transcription of the pro-tumorigenic TNF-NF- $\mathrm{KB}$ gene network [218]; proliferation and migration [219]; AR activity [220]; cell growth [222]

Cell proliferation and biochemical recurrence after radical prostatectomy [224]; epigenetic crosstalk and PCa progression [225]

\begin{tabular}{|c|c|c|c|}
\hline RBR type & & & \\
\hline PRKN & $\begin{array}{c}\text { Parkin RBR E3 Ubiquitin Protein } \\
\text { Ligase }\end{array}$ & & $\begin{array}{l}\text { Participates in removal of damaged } \\
\text { mitochondria via mitophagy [226] }\end{array}$ \\
\hline \multicolumn{4}{|c|}{ U-box type } \\
\hline CHIP & $\begin{array}{l}\text { U-box type chaperone associated E3 } \\
\text { ligase }\end{array}$ & $\begin{array}{l}\text { JMJD1A [227]; SNPH } \\
\text { [228]; AR/AR-V7 [229]; } \\
\text { AKT signaling pathway } \\
\text { [230]; AR [231-233]; } \\
\text { HIF-1 } \alpha \text { [234]; PRMT5 } \\
\text { [235]; PTEN [236] }\end{array}$ & $\begin{array}{l}\text { AR activity [227]; mitochondrial } \\
\text { dynamics, tumor chemotaxis, invasion, } \\
\text { and metastasis in vivo [228]; } \\
\text { anti-androgen resistance [229]; in vitro } \\
\text { migration and invasion [230]; mitotic } \\
\text { arrest [233]; potential role in PCa } \\
\text { oncogenesis through PRMT5 [235] }\end{array}$ \\
\hline UBE4A & $\begin{array}{l}\text { Ubiquitin-protein ligase that probably } \\
\text { functions as an E3 ligase; may also } \\
\text { function as an E4 ligase } \\
\text { complementing actions of another E3 } \\
\text { ubiquitin ligase }\end{array}$ & $\begin{array}{l}\text { Interleukin-like EMT } \\
\text { inducer (ILEI) [237] }\end{array}$ & In vitro migration and invasion [237] \\
\hline \multicolumn{4}{|c|}{ HECT type } \\
\hline EDD & $\begin{array}{l}\text { E3 ubiquitin-protein ligase, which is a } \\
\text { component of the N-end rule } \\
\text { pathway }\end{array}$ & $\begin{array}{l}\text { Wnt } / \beta \text {-Catenin } \\
\text { signaling }[238]\end{array}$ & $\begin{array}{l}\text { Sensitivity of hormone-refractory PCa } \\
\text { to docetaxel in vitro and in vivo [238] }\end{array}$ \\
\hline
\end{tabular}


Table 3. Cont.

\begin{tabular}{|c|c|c|c|}
\hline $\begin{array}{l}\text { (Component of) } \\
\text { E3 Ligase }\end{array}$ & Description & $\begin{array}{l}\text { Affected Protein(s) } \\
\text { and/or Signaling } \\
\text { Pathways }\end{array}$ & Effects on Processes \\
\hline E6AP & $\begin{array}{l}\text { The founding member of the HECT } \\
\text { (Homologous to E6AP Carboxyl } \\
\text { Terminus) domain E3 ligases }\end{array}$ & $\begin{array}{l}\text { NDRG1 [239], p27 [240]; } \\
\text { PI3K, AKT [241,242] } \\
\text { mTOR [241] }\end{array}$ & $\begin{array}{l}\text { Acquisition of mesenchymal features, } \\
\text { migration, ability for } \\
\text { anchorage-independent growth [239]; } \\
\text { tumor growth [240]; proliferation and } \\
\text { invasion in bone metastasis [241]; cell } \\
\text { growth, proliferation, apoptosis [242]; } \\
\text { cellular senescence in vivo, } \\
\text { radiation-induced cell death [243] }\end{array}$ \\
\hline HACE1 & $\begin{array}{l}\text { HECT domain and ankyrin } \\
\text { repeat-containing ubiquitin ligase }\end{array}$ & & $\begin{array}{c}\text { HACE1 is a critical chromosome } 6 \mathrm{q} 21 \\
\text { tumor suppressor involved in prostate } \\
\text { cancer [244] }\end{array}$ \\
\hline HECTD4 & $\begin{array}{l}\text { Probable HECT domain E3 } \\
\text { ubiquitin-protein ligase }\end{array}$ & AR, MYC [138] & $\begin{array}{c}\text { Tumorigenicity of AR-positive PCa } \\
\text { cells [138] }\end{array}$ \\
\hline HUWE1 & $\begin{array}{l}\text { WWE domain-containing protein 1, } \\
\text { E3 ubiquitin protein ligase }\end{array}$ & $\begin{array}{c}\text { HK2 [245]; c-MYC } \\
{[246,247]}\end{array}$ & $\begin{array}{c}\text { Metabolism and cancer stem cell } \\
\text { expansion [245]; survival [246]; } \\
\text { proliferation [246,247] and migration } \\
\text { in vitro, and explant growth in vivo } \\
\text { [247] }\end{array}$ \\
\hline ITCH/AIP4 & $\begin{array}{l}\text { HECT-type E3 ubiquitin transferase } \\
\text { Itchy homolog }\end{array}$ & ErbB3 [248] & $\begin{array}{c}\text { ErbB3 ubiquitination and degradation } \\
\text { in cancer cells through } \\
\text { JNK1/2-dependent ITCH/AIP4 } \\
\text { activation [248] }\end{array}$ \\
\hline Nedd4 & $\begin{array}{l}\text { Comprised of a catalytic C-terminal } \\
\text { HECT domain and N-terminal C2 } \\
\text { domain and WW domains } \\
\text { responsible for cellular localization } \\
\text { and substrate recognition }\end{array}$ & $\begin{array}{l}\text { IRS-2 [249]; AR [250]; } \\
\text { ErbB3 levels and } \\
\text { signaling [251] }\end{array}$ & $\begin{array}{l}\text { IGF signaling and mitogenic activity } \\
\text { [249]; cancer cell proliferation in vitro } \\
\text { and in vivo; sensitization of cancer cells } \\
\text { for growth inhibition by an anti-ErbB3 } \\
\text { antibody [251] }\end{array}$ \\
\hline SMURF1 & $\begin{array}{l}\text { SMAD specific E3 ubiquitin protein } \\
\text { ligase } 1\end{array}$ & PTEN [252] & PCa progression [252]; invasion [253] \\
\hline WWP1 & $\begin{array}{l}\text { WW domain-containing E3 ubiquitin } \\
\text { protein ligase-1 }\end{array}$ & $\begin{array}{l}\text { TGF } \beta \text { [254]; p63 [255]; } \\
\text { KLF5 [256] }\end{array}$ & $\begin{array}{l}\text { Migration and invasion [257]; 22Rv1 } \\
\text { cells colony formation; PC-3 cells } \\
\text { proliferation and TGF } \beta \text {-mediated } \\
\text { growth inhibition [254]; apoptosis [255] }\end{array}$ \\
\hline WWP2 & $\begin{array}{l}\text { WW Domain Containing E3 } \\
\text { Ubiquitin Protein Ligase } 2\end{array}$ & $\begin{array}{l}\text { SUMO1-modified PTEN } \\
\text { [258] }\end{array}$ & PCa development [258] \\
\hline
\end{tabular}

On the example of AR ubiquitination, it is evident that the status and the type (site and the number of units involved) of ubiquitination determine whether upregulation or downregulation of a process (AR transcription activity) will occur. In addition, some ubiquitination proteins, such as SPOP regulate global, while the others, like SIAH2, only specific pools of AR. This emphasizes the versatile role that ubiquitination plays in cellular processes and the importance of its tight regulation.

In addition to E3 ligases, there are several publications exploring the roles of E2 enzymes in prostate cancer. It was shown that ubiquitin conjugating enzyme E2T (UBE2T) exhibits oncogenic properties [259] while genetic ablation of Ube2o (ubiquitin conjugating enzyme E2O) impairs progression of prostate cancer. UBE2O targets AMPKa2 for ubiquitination and degradation and UBE2O blockade inhibits tumorigenesis through AMPKa2 restoration [260]. Furthermore, MYLIP is an E3 ubiquitin-protein ligase whose activity depends on E2 enzymes of the UBE2D family and that was shown to affect AR activity in prostate cancer [172]. 
In conclusion, prostate cancer biology is widely influenced by the actions of enzymes involved in ubiquitination and the main players that drive prostate carcinogenesis are affected and regulated by the UPS system. Understanding of the so-called "ubiquitin code" [261] of prostate cancer through ubiquitomics would add in attempts to dissect the driving events of this disease.

\subsection{SUMOylation}

SUMOylation is the covalent addition of Small Ubiquitin-related MOdifier (SUMO) proteins of about $12 \mathrm{kDa}$ and 100 amino acids to other proteins via an isopeptide bond between the $\mathrm{C}$ terminal carboxyl group on the SUMO protein and the amino group on the lysine of the substrate protein. SUMO proteins have four isoforms (SUMO-1, SUMO-2, SUMO-3, and SUMO-4). Although not highly similar at the level of amino acid sequence, SUMO-1 and ubiquitin are related at the levels of secondary and tertiary structures and, consequently the processes of SUMOylation and ubiquitination are mechanistically similar [123]. The SUMOylation process is also executed in three enzymatic steps: SUMO-activation by the enzyme E1 (such as SUMO-activating enzyme SAE1/2); SUMO-conjugation by the enzyme E2 (UBC9-the only SUMO E2 conjugating enzyme discovered to date and the best-characterized E2 enzyme [262]); and SUMO-ligation by the enzyme E3 (such as PIAS/RANBP2/hPC2). The specificity for the target protein of SUMOylation is thought to reside within E2 enzyme. By the in vitro experiments it was indicated that UBC9 is sufficient for binding to the SUMO moiety and transferring SUMO to substrate proteins, but, recently it was suggested that a specific E3 ligase might be required for efficient SUMOylation in vivo by acting as scaffold and helping to add specificity to the SUMOylation reaction [263]. As indicated above, SUMO E3 ligases are classified into three groups: the protein inhibitor of activated STAT (PIAS) family proteins, the polycomb protein Pc2, and RANBP2 (RAN Binding Protein 2, localized to the nuclear pore complex) [263]. SUMOylation is reversible process and de-SUMOylation is catalyzed by SUMO proteases named Sentrin/SUMO-specific Proteases (SENPs), which cleave the terminal glycine of SUMO, releasing it from its core protein to recycle SUMO molecules. This process keeps the low detectable levels of SUMOylated proteins in cells $(5-10 \%$ of substrate proteins) [127]. There are six SENP enzymes in mammals, which contain a highly conserved 200 amino acid catalytic domain responsible for the enzymatic activity. Other domains vary between SENPs and play roles in subcellular localization and possibly substrate recognition [263]. On the list of experimentally documented and predicted PTMs, SUMOylation, unlike ubiquitination, is not among the top ten processes [11]. Furthermore, SUMOylation, unlike ubiquitination, does not directly target proteins for degradation but is thought to determine cellular localization and, in some cases, can regulate transcriptional activity or act as a protective mechanism to prevent structural alterations to proteins in response to cellular stress $[128,264]$. Since quite often the same residues within proteins are targeted by SUMOylation and ubiquitination, SUMOylation may compete with the ubiquitination process $[128,264]$. Additionally, the processes influenced by SUMOylation include subnuclear structure formation, protein-protein interactions, cellular metabolism, regulation of several intracellular signaling pathways, cell differentiation, cell cycle, DNA damage repair, apoptosis, tissue development, and disease progression [263].

By using quantitative proteomics to identify SUMOylated proteins in SUMO stably transfected PC-3 cells Wen et al. [39] (Table 1) found more than 900 putative target proteins of SUMO. Additionally, they have shown that mutation of newly identified SUMO modification sites of USP39 further promotes the proliferation-enhancing effect of USP39 on prostate cancer cells. Among the SUMOylated proteins in prostate cancer are the driving proteins such as AR [134,263,265-270], PTEN [271], p53 [216,272], ATF3 [273], FOXA1 [274], FOXA2 [275], CSR1 [276], TBL1 and TBLR1 [277], WWOX [278], pontin [279] SLUG [280], and SNAIL1 [281]. Two SUMOylation residues (K386 and K520) are defined in AR [134]. The PIAS proteins are reported to act as SUMO-E3 ligases for the SUMO- 1 and SUMO-2/3 conjugation to AR in vivo and in vitro $[263,265,266]$. Recently it was shown that SUMO-3 
modification by PIAS1 modulates AR cellular distribution and stability [267]. By using wild type and doubly SUMOylation site mutated AR, Sutinen et al. showed that SUMOylation does not simply repress the AR activity, but it regulates AR's interaction with the chromatin and the target gene selection [268]. Further, androgen-induced, dynamic SUMOylation is linked to the activity cycles of AR in the cell nucleus and chromatin binding, while the stress-induced SUMO-2/3 modifications sustain the solubility of the AR and protect it from short-term proteotoxic insults such as hyperthermia in the nucleus [269]. Clinically isolated substitutions at a SUMOylation related sites in AR lead to SUMOylation that affects multiple endogenous genes. These alterations in AR SUMOylation play significant roles in AR-based diseases, oligospermia, androgen insensitivity syndrome, and recurrent prostate cancer [270].

Of other proteins critically involved in prostate tumorigenesis, it was shown that SUMO-1 modification of PTEN regulates tumorigenesis by controlling its association with the plasma membrane, which in turn affects PI3K/AKT pathway [271]. Additionally, androgen induces SUMO-mediated p53 nuclear export that promotes treatment-resistant prostate cancer [272]. Pro-invasive properties of prostate cancer cells are also regulated by SUMOylation; it was shown that SNAIL1 is regulated by SUMOylation in response to TGF $\beta$ stimulation [281] and that p14ARF stabilizes SLUG through increased SUMOylation at lysine residue 192 [280].

Studies that examined the roles of proteins involved in SUMOylation revealed that PIAS1 is a central factor that influences prostate cancer cell proliferation and survival and tumor growth in vitro and in vivo most probably through increased expression of tumor suppressor p21 and declined expression of anti-apoptotic protein Mcl1. Moreover, the same study suggests that PIAS1 is a valid target in docetaxel resistant cells [282]. The work from Palvimo laboratory revealed that PIAS1 is a chromatin-bound AR coregulator that functions in a target gene selective fashion to regulate prostate cancer cell growth [283]. Recent work from the Culig laboratory established PIAS1 as a positive feedback regulator of AR signaling, which is achieved through enhanced AR stabilization in prostate cancer [284].

SENP1 is reported to be the de-SUMOylation enzyme that cleaves the SUMO-1 group from SUMOylated AR protein and reverses the ligand-induced SUMOylation of AR to help to fine tune the cellular responses to androgens in a target promoter-selective manner [285]. SENP1 also promotes EMT of prostate cancer cells via regulating SMAD4 de-SUMOylation [286] and it regulates PTEN stability to promote prostate cancer development [258]. In a mouse model, Bawa-Khalfe et al. showed that SENP1 overexpression induces transformation of the normal prostate gland and gradually promotes the onset of high-grade prostatic intraepithelial neoplasia through induction of HIF- $1 \alpha$-dependent angiogenesis and increased cell proliferation [287]. Similarly, Wan et al. showed that SENP1 promotes prostate cancer progression and metastasis [288]. As a connection to the ubiquitination pathway in prostate cancer, it was shown that SPOP promotes cellular senescence by degrading the SENP7 [289]. Taken together, these results indicate that investigated SENPs in prostate cancer induce cancer progression and a malignant phenotype, while the work on SUMOylation revealed the frequent modification of prostate cancer driving proteins.

\subsection{Acetylation}

The acetylation of proteins is a dynamic and highly specific PTM in which acetyl donors (such as acetyl-CoA) transfer acetyl groups to the proteins under the catalysis of acetyltransferase. In the opposite reaction, proteins are deacetylated by the actions of deacetylases. Protein acetylation is one of the main regulators of gene transcription since most histone acetyltransferases are located in the nucleus where they act as transcriptional co-activators [290]. Historically, acetylation was first discovered as a process affecting histones and if lysine is acetylated, histones will no longer be positively charged, so the binding of DNA to the histone is relaxed, which facilitates gene transcription. However, currently $>100$ non-histone proteins that are involved in transcription are shown to be affected by acetylation confirming that regulation of gene transcription is a major role 
of non-histone protein acetylation too [291]. Protein acetylation is also associated with protein degradation and it can regulate a variety of signaling pathways as well as the cell cycle [292]. To recognize the large amount of non-histone protein acetylation, histone acetyltransferases (HATs) and histone deacetylases (HDACs) were renamed to lysine acetyltransferases (KATs) and lysine deacetylases (KDACs), respectively. The documented roles of these proteins in prostate cancer are summarized in Table 4.

Globally, hypoacetylation and excessive histone deacetylase activity in prostate cancer cells has been observed $[293,294]$ and global histone modification patterns (acetylation and dimethylation in histones $\mathrm{H} 3$ and $\mathrm{H} 4$ ) predict progression, development and risk of prostate cancer recurrence $[295,296]$. These patterns change under chronic hypoxic conditions in the prostate [297]. Additionally, acetylation of the histone variant H2A.Z occurs at active promoters and is associated with oncogene and neo-enhancers activation in prostate cancer [298]. The transition of androgen-dependent to -independent prostate cancer was suggested to be associated with the changes in protein lysine acetylation as the number of cellular proteins undergoing acetylation in the androgen-dependent prostate cancer was higher as compared to the androgen-independent [299]. H3-lysine-27 acetylation (H3K27ac) ChIP-seq in Enzalutamide (Enz)-resistant CRPC cells identified a group of super enhancers that are abnormally activated in Enz-resistant CRPC cells and associated with enhanced transcription of a subset of tumor promoting genes such as CHPT1 that drive anti-androgen therapy resistance in prostate cancer [300]. Takeda et al. showed that the AR candidate enhancer becomes histone acetylated (H3K27ac) in CRPC tumors and that deacetylation of this enhancer element effectively suppresses AR signaling and decreases sensitivity to Enz [301]. Among those listed in Table 4, other proteins that direct AR acetylation include Arrest defective protein 1 (ARD1) that is androgen induced [302] and promotes AR dissociation from HSP90 complex and prostate tumorigenesis [303]. Acetylation of AR enhances coactivator binding [304] and in turn histone acetylation, among other factors, defines genomic AR-occupied regions [305]. Deregulation of AR expression is a driver of chromatin relaxation and $\mathrm{AR} /$ androgen-regulated bromodomain-containing proteins (BRDs), which are histone acetylation readers, mediate this effect, which helps to stratify patients with tumors in which BRD-mediated TF binding is enhanced or modified as cancer progresses. Those patients could potentially benefit from combination therapy targeting bromodomains [306].

Table 4. Roles of (de-)acetylating enzymes in prostate cancer.

\begin{tabular}{|c|c|c|}
\hline Enzyme & Involvement(s) in Prostate Cancer & Ref. \\
\hline \multicolumn{3}{|l|}{ KATs } \\
\hline \multirow[t]{2}{*}{ КАT2A } & $\begin{array}{l}\text { KAT2A inhibition prevents interleukin (IL) 6-induced PCa metastases through } \\
\text { PI3K/PTEN/AKT signaling by inactivating Egr-1 }\end{array}$ & [307] \\
\hline & $\begin{array}{l}\text { Association between AR and histone acetyltransferase KAT2A increases histone H3 } \\
\text { acetylation level on cis-regulatory elements of AR target genes }\end{array}$ & [308] \\
\hline КАТ2B & $\begin{array}{c}\text { Promotes PKM2 acetylation and decreases PKM2 protein level through degradation } \\
\text { through chaperone-mediated autophagy; promotes tumor growth }\end{array}$ & [309] \\
\hline $\begin{array}{c}\text { CBP } \\
\text { (KAT3A) }\end{array}$ & CBP loss cooperates with PTEN haploinsufficiency to drive PCa & [310] \\
\hline \multirow{3}{*}{ p300 (КАТ3B) } & $\begin{array}{l}\text { p300-mediated acetylation of histone demethylase JMJD1A prevents its degradation by } \\
\text { CHIP and enhances its activity }\end{array}$ & [227] \\
\hline & $\begin{array}{c}\text { p300/CBP inhibition enhances the efficacy of programmed death-ligand } 1 \text { blockade } \\
\text { treatment }\end{array}$ & [311] \\
\hline & Therapeutic targeting of the CBP/p300 bromodomain blocks the growth of CRPC & [312] \\
\hline
\end{tabular}


Table 4. Cont.

\begin{tabular}{|c|c|c|}
\hline Enzyme & Involvement(s) in Prostate Cancer & Ref. \\
\hline & p300 regulates fatty acid synthase expression, lipid metabolism and PCa growth & [313] \\
\hline & p300 regulates AR degradation and PTEN-deficient prostate tumorigenesis & [314] \\
\hline & $\begin{array}{l}\text { The assembly of a macromolecular complex involving CBP/p300 results in acetylation of } \\
\text { p53 at K373, a critical PTM required for its biological activity }\end{array}$ & [315] \\
\hline & $\begin{array}{l}\text { SKP2 is acetylated by p300 at K68 and K71, which promotes its cytoplasmic retention, and } \\
\text { cytoplasmic SKP2 enhances cellular migration through ubiquitination and destruction of } \\
\text { E-cadherin }\end{array}$ & [202] \\
\hline & $\begin{array}{l}\text { p300 is the dominant coregulator of the CBP/p300 pair for androgen-regulated gene } \\
\text { expression in C4-2B cells; p300 is required at an early stage of chromatin remodeling and } \\
\text { transcription complex assembly after binding of AR to the gene but before many critical } \\
\text { histone modifications occur }\end{array}$ & [316] \\
\hline & Function in the survival and invasion pathways of PCa cell lines & [317] \\
\hline & $\begin{array}{c}\text { p300 and CBP stimulate estrogen receptor-beta (ER- } \beta) \text { signaling and regulate cellular } \\
\text { events in PCa }\end{array}$ & [318] \\
\hline & $\begin{array}{l}\text { IL-4 activates AR through enhanced expression of CBP/p300 and its histone } \\
\text { acetyltransferase activity }\end{array}$ & [319] \\
\hline & $\begin{array}{c}\text { p300 modulates nuclear morphology in PCa and is required for androgen depletion } \\
\text { independent activation of the AR }\end{array}$ & [320] \\
\hline & $\begin{array}{l}\text { p300 mediates STAT3 acetylation on Lys685, which mediates STAT3 dimerization and is } \\
\text { reversible by type I HDAC }\end{array}$ & [321] \\
\hline & $\begin{array}{c}\mathrm{CBP} / \mathrm{p} 300 \text { is a component of a transcriptional complex that regulates SRC-dependent } \\
\text { hypoxia-induced expression of VEGF }\end{array}$ & [322] \\
\hline & $\begin{array}{l}\text { The downregulation of p300 inhibits PCa cell proliferation both at the basal level and on } \\
\text { IL6 stimulation }\end{array}$ & [323] \\
\hline & p300 mediates androgen-independent transactivation of the AR by IL6 & [324] \\
\hline & $\begin{array}{l}\text { p300 and p300/CBP acetylate the AR at sites governing hormone-dependent } \\
\text { transactivation }\end{array}$ & [325] \\
\hline \multirow{10}{*}{$\begin{array}{l}\text { Tip60 } \\
\text { (KAT5) }\end{array}$} & $\begin{array}{l}\text { Negatively regulates the proliferation of LNCaP cells via the caspase 3-dependent } \\
\text { apoptosis pathway }\end{array}$ & [326] \\
\hline & Associated with resistance to X-ray irradiation & [327] \\
\hline & $\begin{array}{l}\text { Inhibition by TH1834 increases the effect of ionizing radiation in PC-3 and DU145 cells, } \\
\text { induces apoptosis and increases unrepaired DNA damage }\end{array}$ & [328] \\
\hline & $\begin{array}{l}\text { Interacts with ER- } \beta \text { to regulate endogenous gene expression such as CXCL12 and cyclin } \\
\text { D2 }\end{array}$ & {$[329,330]$} \\
\hline & KAT5 and KAT6B positively regulate cell proliferation through PI3K/AKT signaling & [331] \\
\hline & $\begin{array}{l}\text { Inhibition by NU9056 induces a decrease of AR, PSA, p21 and p53 levels in LNCaP cells, } \\
\text { which might explain the increase of apoptosis and the decrease of proliferation }\end{array}$ & [332] \\
\hline & $\begin{array}{l}\text { Overexpression increases the acetylation of the AR and its localization in the nucleus and } \\
\text { promotes cell proliferation }\end{array}$ & [333] \\
\hline & Tip60 and $\beta$-catenin complexes regulate expression of metastasis suppressor gene KAI1 & [334] \\
\hline & $\begin{array}{l}\text { A possible role for Tip60 in the molecular pathway leading to the development of } \\
\text { androgen-independent PCa following long-term androgen deprivation therapy }\end{array}$ & [335] \\
\hline & $\begin{array}{c}\text { Tip60 and HDAC1 regulate AR activity through changes to the acetylation status of the } \\
\text { receptor }\end{array}$ & [336] \\
\hline \multirow{2}{*}{$\begin{array}{l}\text { MYST1 } \\
\text { (KAT8) }\end{array}$} & Regulates androgen signaling in PCa cells & [337] \\
\hline & Regulates NF- $\mathrm{KB}$ and AR functions during proliferation of PCa cells & [338] \\
\hline
\end{tabular}


Table 4. Cont.

\begin{tabular}{|c|c|c|}
\hline Enzyme & Involvement(s) in Prostate Cancer & Ref. \\
\hline & $\begin{array}{l}\text { FOXP3 induces H4K16 acetylation and H3K4 trimethylation and activation of multiple } \\
\text { genes by recruiting KAT8 and causing displacement of PLU-1 }\end{array}$ & [339] \\
\hline \multicolumn{3}{|l|}{ KDACs } \\
\hline Class I & $\begin{array}{l}\text { Maspin induction is a critical epigenetic event altered by class I HDACs in the restoration } \\
\text { of balance to delay proliferation and migration ability of PCa cells }\end{array}$ & [340] \\
\hline \multirow{3}{*}{ HDAC1 } & $\begin{array}{l}\text { KLF5 inhibits STAT3 activity and tumor metastasis in PCa by suppressing IGF1 } \\
\text { transcription cooperatively with HDAC1 }\end{array}$ & [341] \\
\hline & Involved in E-cadherin expression in PCa cells & [342] \\
\hline & $\begin{array}{l}\text { Ubiquitination of the AR and HDAC1 may constitute an additional mechanism for } \\
\text { regulating AR function; HDAC1 and MDM2 function co-operatively to reduce AR } \\
\text { mediated transcription that is attenuated by the HAT activity of the AR co-activator Tip60 }\end{array}$ & [343] \\
\hline HDAC3 & $\begin{array}{l}\text { Genetic knockdown of either HDAC1 or HDAC3 can suppress expression of } \\
\text { AR-regulated genes, recapitulating the effect of HDAC inhibitor treatment }\end{array}$ & [344] \\
\hline \multirow{2}{*}{ HDAC4 } & $\begin{array}{l}\text { Positive regulator of AR SUMOylation, revealing a deacetylase-independent mechanism } \\
\text { of HDAC action in PCa cells }\end{array}$ & [345] \\
\hline & $\begin{array}{c}\text { Recruitment of HDAC4 by transcription factor YY1 represses HOXB13 to affect cell } \\
\text { growth in AR-negative PCa }\end{array}$ & [346] \\
\hline \multirow{3}{*}{ HDAC6 } & Synergistic interaction with MEK-inhibitors in CRPC cells & [347] \\
\hline & $\begin{array}{l}\text { Metastatic prostate cancer-associated p62 inhibits autophagy flux and promotes EMT by } \\
\text { sustaining the level of HDAC6 }\end{array}$ & [348] \\
\hline & $\begin{array}{l}\text { Regulates AR hypersensitivity and nuclear localization via modulating Hsp90 acetylation } \\
\text { in CRPC }\end{array}$ & [349] \\
\hline HDAC7 & $\begin{array}{l}\text { HDAC7 localizes to the mitochondrial inner membrane space of prostate epithelial cells } \\
\text { and exhibits cytoplasmic relocalization in response to initiation of the apoptotic cascade, } \\
\text { which highlights a link between HDACs, mitochondria, and programmed cell death }\end{array}$ & [350] \\
\hline HDAC11 & $\begin{array}{l}\text { HDAC11 depletion is sufficient to cause cell death and to inhibit metabolic activity in } \\
\text { PC-3 cells }\end{array}$ & [351] \\
\hline \multirow{11}{*}{ SIRT1 } & Modulates the sensitivity of PCa cells to vesicular stomatitis virus oncolysis & [352] \\
\hline & $\begin{array}{c}\text { Mesenchymal stem cells overexpressing SIRT1 inhibit PCa growth by recruiting NK cells } \\
\text { and macrophages }\end{array}$ & [353] \\
\hline & $\begin{array}{l}\text { Loss of miR-449a in ERG-associated PCa promotes the invasive phenotype by inducing } \\
\text { SIRT1 }\end{array}$ & [354] \\
\hline & $\begin{array}{l}\text { SIRT1 and LSD1 competitively regulate KU70 functions in DNA repair and mutation } \\
\text { acquisition }\end{array}$ & [355] \\
\hline & $\begin{array}{c}\text { The silencing of SIRT1 gene in PC-3 cells suppresses the movement, migration, and } \\
\text { invasion, possibly via reversing the EMT process }\end{array}$ & [356] \\
\hline & $\begin{array}{l}\text { Loss of Sirt1 promotes prostatic intraepithelial neoplasia, reduces mitophagy, and delays } \\
\text { Park2 translocation to mitochondria }\end{array}$ & [226] \\
\hline & Existence of SIRT1 and MPP8 crosstalk in E-cadherin gene silencing and EMT & [357] \\
\hline & Regulation of histone H2A.Z expression is mediated by SIRT1 in PCa & [358] \\
\hline & Enhances matrix metalloproteinase-2 expression and tumor cell invasion of PCa cells & [359] \\
\hline & $\begin{array}{l}\text { SIRT1 induces EMT by cooperating with EMT transcription factors and enhances PCa cell } \\
\text { migration and metastasis }\end{array}$ & [360] \\
\hline & $\begin{array}{c}\text { Inhibition of cortactin and SIRT1 expression attenuates migration and invasion of DU145 } \\
\text { cells }\end{array}$ & [361] \\
\hline
\end{tabular}


Table 4. Cont.

\begin{tabular}{|c|c|c|}
\hline Enzyme & Involvement(s) in Prostate Cancer & Ref. \\
\hline & $\begin{array}{l}\text { Deacetylation of FOXO3 by SIRT1 or SIRT2 leads to SKP2-mediated FOXO3 } \\
\text { ubiquitination and degradation }\end{array}$ & [201] \\
\hline & $\begin{array}{l}\text { Disruption of a SIRT1-dependent autophagy checkpoint in the prostate results in prostatic } \\
\text { intraepithelial neoplasia lesion formation }\end{array}$ & [362] \\
\hline & $\begin{array}{c}\text { Inhibition of SIRT1 activity increases the chemosensitivity of androgen-refractory PCa } \\
\text { cells }\end{array}$ & [363] \\
\hline & $\begin{array}{l}\text { SIRT1 inhibition at the activity level as well as via shRNA results in a significant } \\
\text { inhibition in the growth and viability of human PCa cells; inhibition of SIRT1 causes an } \\
\text { increase in FOXO1 acetylation and transcriptional activation in PCa cells }\end{array}$ & [364] \\
\hline & $\begin{array}{l}\text { SIRT1 inhibition causes a decrease in cell growth, cell viability and the colony formation } \\
\text { ability and an increase in FOXO1 acetylation and subsequent transcriptional activation } \\
\text { regardless of p53 status; SIRT1 inhibition results in an increase in senescence in PC-3-p53 } \\
\text { (wild type p53) cells whereas it results in an increase in apoptosis in PC-3 (lack p53) cells }\end{array}$ & [365] \\
\hline & $\begin{array}{l}\text { Upregulation of SIRT1 expression may play an important role in promoting cell growth } \\
\text { and chemoresistance in androgen-refractory PC-3 and DU145 cells }\end{array}$ & [366] \\
\hline & $\begin{array}{l}\text { Required for antagonist-induced transcriptional repression of androgen-responsive genes } \\
\text { by the AR }\end{array}$ & [367] \\
\hline & SIRT1 is a regulator of AR expression and function & [368] \\
\hline & FOXO1 activity in PCa cells is inhibited by deacetylation by SIRT1 & [369] \\
\hline SIRT2 & $\begin{array}{l}\text { Dysregulation of SIRT2 and histone H3K18 acetylation pathways associates with adverse } \\
\text { PCa outcomes }\end{array}$ & [370] \\
\hline \multirow{5}{*}{ SIRT3 } & $\begin{array}{c}\text { Transcriptional repression of SIRT3 potentiates mitochondrial aconitase activation to } \\
\text { drive aggressive PCa to the bone }\end{array}$ & [371] \\
\hline & $\begin{array}{c}\text { SIRT3 and SIRT6 promote PCa progression by inhibiting necroptosis-mediated innate } \\
\text { immune response }\end{array}$ & [372] \\
\hline & $\begin{array}{l}\text { Inhibits PCa metastasis through regulation of FOXO3A by suppressing Wnt/ } \beta \text {-catenin } \\
\text { pathway }\end{array}$ & [373] \\
\hline & Inhibits PCa by destabilizing c-MYC through regulation of the PI3K/AKT pathway & [374] \\
\hline & $\begin{array}{c}\text { Inactivation of SIRT3 leads to elevated SKP2 acetylation, which leads to increased SKP2 } \\
\text { stability through impairment of the CDH1-mediated proteolysis pathway resulting in } \\
\text { increase of SKP2 oncogenic function; cells expressing an acetylation-mimetic mutant } \\
\text { display enhanced cellular proliferation and tumorigenesis in vivo }\end{array}$ & [202] \\
\hline SIRT4 & Mitochondrial PAK6 inhibits PCa cell apoptosis via the PAK6-SIRT4-ANT2 complex & [375] \\
\hline SIRT5 & $\begin{array}{l}\text { SIRT } 5 \text { regulates the proliferation, invasion, and migration of PCa cells through } \\
\text { acetyl-CoA acetyltransferase } 1\end{array}$ & [376] \\
\hline \multirow{2}{*}{ SIRT6 } & E2F1 enhances glycolysis through suppressing Sirt6 transcription in cancer cells & [377] \\
\hline & Inhibition of SIRT6 reduces cell viability and increases sensitivity to chemotherapeutics & [378] \\
\hline \multirow{3}{*}{ SIRT7 } & $\begin{array}{l}\text { SIRT7 depletion inhibits cell proliferation and androgen-induced autophagy by } \\
\text { suppressing the AR signaling in PCa }\end{array}$ & [379] \\
\hline & Promotes PCa cell aggressiveness and chemoresistance & [380] \\
\hline & SIRT7 inactivation reverses metastatic phenotypes & [381] \\
\hline
\end{tabular}

Of other proteins implicated in prostate cancer, transcriptional regulator and tumor suppressor Id4 was shown to regulate transcriptional activity of wild type and mutant p53 via K373 acetylation in prostate cancer [315,382], which directs selective transcription complex assembly [383]. Mechanistic insights into p53 acetylation come from studies that showed that resveratrol enhances p53 acetylation and apoptosis in prostate cancer by inhibiting MTA1/NuRD complex [384]. It also regulates PTEN/AKT pathway through 
inhibition of the same complex [385]. Metastasis-associated protein 1 (MTA1) is a part of the nucleosome remodeling deacetylation (NuRD) corepressor complex that mediates posttranslational modifications of histones and non-histone proteins, which leads to transcriptional repression.

The transcription factors Krüppel-like factor 5 and 6 (KLF5 and KLF6) are critically involved in prostate cancer progression [386,387]. Recently, it was shown that KLF5 acetylation regulates luminal differentiation of basal progenitors in prostate development and regeneration [388] and is involved in TGF $\beta$ caused docetaxel resistance [389]. Remarkably, the acetylation status of KLF5 determines whether this protein will switch from its tumor suppressor function to tumor promoter in prostate cancer cells [390]. Additionally, different expression patterns of acetylated and unacetylated KLF5 in prostatic epithelial cells have been reported [391]. For KLF6, it was also suggested that acetylation may regulate its function [392]. In conclusion, global as well as single protein aberrant acetylation is critically involved in many aspects of prostate cancer progression.

\subsection{Lipidation}

Protein lipidation that includes cysteine palmitoylation, N-terminal glycine myristoylation and cystein prenylation (farnesylation and geranylgeranylation) is frequently detected in eukaryotic proteins [11] and is involved in membrane trafficking, protein localization and secretion, signal transduction, and apoptosis [393]. In prostate cancer, the palmitoyl-protein signature of extracellular vesicles (EVs) was reported [40] and it was suggested that palmitoylation plays a role in the sorting of the EV-bound secretome. Other reports investigated changes in palmitoylation after androgen treatment [42,43] and DHHC3 palmitoyltransferase ablation [41] (Table 1).

Of the enzymes involved in lipidation, it was shown that fatty acid synthase (FASN), an enzyme that catalyzes de novo synthesis of the fatty acid palmitate, increases prostate cancer cell adhesiveness, impairs HGF-mediated cell migration and reduces three-dimensional (3D) invasion by mediating actin cytoskeletal remodeling downstream of palmitoylated atypical GTPase RHOU [394,395]. Moreover, p63 cell survival promoting capabilities engage the actions of FASN [396] and inhibition of FASN induces endoplasmic reticulum stress in prostate cancer cells [397] as well as down-regulates c-MET expression [398].

Another lipidation enzyme, lysophosphatidylcholine acyltransferase of histone serine palmitoylation (LPCAT1) was found to mediate CRPC growth via nuclear re-localization and histone $\mathrm{H} 4$ palmitoylation in an androgen-dependent fashion by increasing mRNA synthesis rates. Additionally, LPCAT1 overexpression led to CRPC cell resistance to treatment with paclitaxel [399].

Farnesyl diphosphate synthase (FDPS), a mevalonate pathway enzyme that synthesizes isoprenoids, plays an oncogenic role in PTEN-deficient prostate cancer progression [400]. Inhibition of FDPS by zoledronic acid reduces growth and clonogenicity of human and murine PCa cells in 2D and 3D by disrupting AKT and ERK signaling through direct interference of small GTPases protein prenylation. Among the numerous products including cholesterol, vitamin K, coenzyme Q10, and all steroid hormones, the mevalonate synthesis pathway produces intermediates for isoprenylation of small GTPases, and it was shown that inhibition of geranylgeranyltransferase (GGTase-I), and farnesyltransferase (FTase) disrupts cytoskeletal organization of human PC-3 prostate cancer cells [401]. Inhibiting geranylgeranyl diphosphate synthesis reduces nuclear AR signaling and progression to neuroendocrine prostate cancer phenotype [402]. The same strategy of targeting protein geranylgeranylation slows tumor development in a murine model of prostate cancer metastasis possibly through reduction in Rap1A geranylgeranylation [403] and reduces adrenal gland tumor burden in a murine model of prostate cancer metastasis [404]. Further to this, statins are a class of inhibitors of 3-hydroxyl3-methylglutaryl coenzyme A (HMG$\mathrm{CoA}$ ) reductase, a key enzyme in synthesis of cholesterol. Antitumoral effects of statins in prostate cancer have been attributed to both cholesterol dependent and independent effects. However, the reduced circulating and cellular cholesterol levels are thought to 
contribute the most [405]. Studies have demonstrated statin therapy to be associated with prostate cancer prevention and favorable clinical outcomes and they suppress tumorigenesis in prostate cancer models [406-410]. In PC-3 cells, statin (atorvastatin, a commonly prescribed statin for treatment of hypercholesterolemia) induces autophagy most likely by inhibiting geranylgeranyl biosynthesis, which suggests that autophagic response to statins may partially underlie the protective effects of statins on prostate cancer progression [411].

Of the individual proteins affected by lipidation, it was shown that alteration of palmitoylation and myristoylation sites change oncogenic potential of constitutively active SRC [412-415] and FYN kinases in prostate cancer [412]. Moreover, the oncogenic effects of AKT are reinforced by its myristoylation and these effects arise, in part, from the tendency of the membrane-targeted form of the protein to reside in cholesterol-rich membrane microdomains [416]. Palmitoylation of the classical sex steroid receptors is required for membrane localization and function [417] and palmitoylation of KAI1/CD82 is necessary for its inhibitory effect on cell migration and invasion [418]. Furthermore, pharmacologically targeting the myristoylation of the FRS2 scaffold protein whose role in prostate cancer has been elaborated in Chapter 3.1, inhibits FGF/FGFR-mediated oncogenic signaling and consequently the prostate cancer progression [419].

\section{Therapeutic Potential of Post-Translational Modifications in Prostate Cancer}

In previous chapters, critical involvement of PTMs in prostate cancer progression has been documented. As such, targeting PTMs offers the opportunity to interfere with crucial events in cancer biology as depicted on Figure 2.

\section{Phosphorylation}

Signalling, cell proliferation, migration, apoptosis, in vivo tumor growth and metastasis formation Kinase inhibitors

\section{SUMOylation}

Protein cellular localization, transcriptional activity SUMO mimics; SUMO enzyme inhibitors; SENP inhibitors

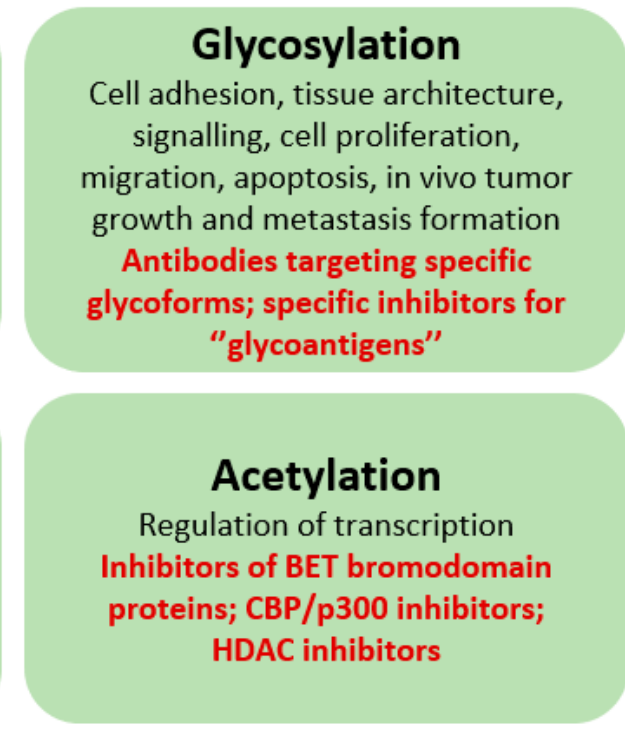

\section{Glycosylation}

ell adhesion, tissue architecture, signalling, cell proliferation, igration, apoptosis, in vivo tumo growth and metastasis formation Antibodies targeting specific glycoforms; specific inhibitors for "glycoantigens"

\section{Acetylation}

Regulation of transcription Inhibitors of BET bromodomain HDAC inhibitors

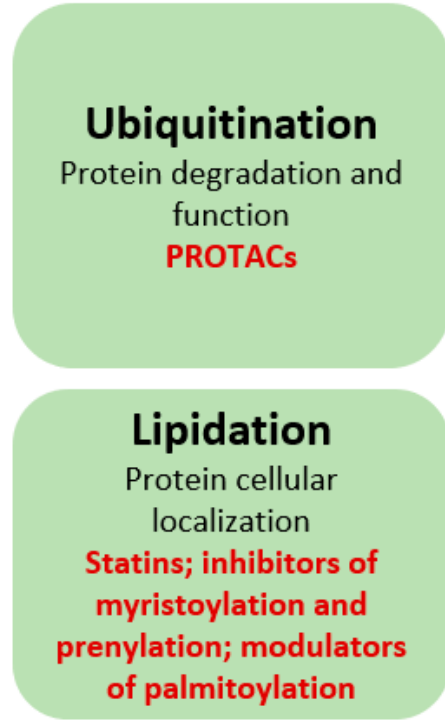

Description of a Figure:

PTM

Roles

Therapeutic strategies

Figure 2. Post-translational modifications, their involvements in cellular processes and therapeutic opportunities.

Since kinases are the driving proteins in both cancer cell growth and dissemination, during the last two decades, several molecules targeting receptor tyrosine kinases were used in oncology as a first or second line therapy in various cancer types [420]. In prostate cancer, tyrosine kinase inhibitors targeting signaling pathways of EGFR, VEGFR, c-SRC family kinases, platelet-derived growth factor and c-MET showed encouraging results in pre-clinical settings but these finding are still waiting to be realized as anticancer drugs as phase III clinical trials did not produce satisfying results [421]. 
Despite promising results in early preclinical studies, targeting the PI3K-AKT-mTOR pathway in prostate cancer appeared to be challenge due to numerous feedback and feedforward loops and redundancy mechanisms that prevent complete blockage of the pathway [6]. Consequently, combinatorial therapies are explored. Targeting PI3K-AKT-mTOR in combination with AR (phase II study of ipatasertib in combination with abiraterone) showed promising results [422], but further research is needed to delineate the crosstalk between the two pathways and to define biomarkers for patient stratification.

Since the mechanisms of resistance to therapy are expected to vary significantly between patients and in individual tumors, another opportunity for prostate cancer management that is based on phosphorylation emerges from phosphoproteome studies. Analyzing phosphoproteomic profiles of cancer patients would contribute to possible patient stratification and this valuable knowledge could be used in the settings of personalized medicine [423]. Personalized phosphoproteomics or the analysis of signaling networks in individual tumors, advances personalized therapy by discovering biomarkers of pathway activity and therefore, suggesting potential targets [424]. Like mentioned in an introductory part, CRPC often arises in a substantial subgroup of patients worsening the treatment options. Neuroendocrine prostate cancer (NEPC) is an aggressive subtype of prostate cancer with poor prognosis that most commonly arises in later stages of prostate cancer as a mechanism of treatment resistance [425]. Clinically distinct therapeutic strategies are considered against NEPC compared to the AR-driven adenocarcinomas. The studies from Beltran and Drake laboratories established that targeting Aurora A [426] and Ret [427] kinases could bring benefit to NEPC patients. Specifically, a phase II clinical trial of the Aurora kinase A inhibitor alisertib for CRPC and NEPC patients established that in a subset of patients with molecular features supporting Aurora A and N-myc activation significant clinical benefit from single agent alisertib could be achieved [426]. On this example it is evident how precision oncology and disease classification based on genomic sequencing that would consider individual qualities of tumors and the status of the main drivers offers possibilities of improvements of prostate cancer therapy by either providing the targets for the treatment or the biomarkers to guide future pre-clinical research and improve clinical trials [428,429].

The strategy to target oncogenic proteins for degradation is widely used in the attempts to develop novel anti-cancer drugs. A proteolysis targeting chimera (PROTAC) consists of one protein-binding molecule that is capable of engaging an E3 ubiquitin ligase, and another that binds to a target protein meant for degradation. In this way, PROTAC is capable of removing specific unwanted proteins. Recently, the first clinical data were reported for AR PROTAC showing some efficacy and good safety profile in men with metastatic CRPC [430]. Considering that AR is heavily affected by other PTMs [44-46,134,431,432], they could potentially be explored in prostate cancer treatment.

SENP [433] and SUMO enzyme inhibitors [434] are studied in the field of prostate cancer and showed efficacy in in vitro studies. While this strategy in prostate cancer still awaits to be further exploited, the (de-)acetylation inhibitors are already used in clinical trials. HDAC inhibitors vorinostat, pracinostat, panobinostat, and romidepsin underwent phase II clinical trials for prostate cancers but results were not satisfying to recommend phase III trials as majority of patients exhibited either toxicity or disease progression [435]. The CBP/p300 bromodomain inhibitor CCS1477, the only CBP/p300 inhibitor currently in clinical trials, is under clinical evaluation for the treatment of prostate cancer [436].

Interference with lipidation showed efficacy in in vivo model where blocking myristoylation of SRC inhibited its kinase activity and suppressed prostate cancer progression [415]. Moreover, statins (inhibitors of cholesterol synthesis) used as a therapy were associated with prostate cancer prevention and favorable clinical outcomes [405].

Although their great importance in cancer progression continues to be shown, glycans are still overlooked in drug discovery strategies, mainly because of the complexity associated with the glycosylation process and technical difficulties in studying this PTM. However, some researchers envision that targeting glycans has the potential to start a new 
era of cancer therapy especially because glycans are actively involved in tumorigenesis and seem to play a role in the failure of existing cancer treatment options [437]. Glycosylation is recognized as an androgen-regulated process essential for prostate cancer cell viability and is a global target for androgen control suggesting that loss of specific glycosylation enzymes might contribute to tumor regression following ADT [105]. Additionally, as mentioned in Chapter 3.2, global glycosylation profiles or those of individual proteins may serve as a source of biomarkers of disease progression and severity.

Taken together, the driving role of PTMs in prostate cancer biology is widely considered in efforts of finding new drugs targeting this disease with some promising compounds reaching far in (pre)clinical and epidemiological studies of prostate cancer. Besides being the targets for the treatment, PTMs offer potential of biomarkers that could guide future research and therapeutic strategies.

\section{Conclusions}

The main drivers of prostate cancer progression, such as AR [44-46,134,431,432], PTEN/PI3K/AKT/mTOR [438], STAT3 [439,440], NKX3.1 [441] are influenced by PTMs, which changes their activity, expression, stability, and localization. Additionally, many enzymes involved in PTMs are deregulated in prostate cancer and this directs prostate cancer cell behaviors. Since their driving role in prostate cancer, PTMs are widely explored in attempts to advance prostate cancer therapy. Proteomics analysis of PTMs in prostate cancer offers valuable information especially in cases when protein expression and/or mutational status do not change in malignancy, but the proteins differ only in the PTMs. Further to this, single protein PTM studies complement proteomics to generate complete catalogue of PTMs in prostate cancer.

Funding: This research was funded by a MY ZABA START 2019 donation from Zagrebačka banka.

Conflicts of Interest: The author declares no conflict of interest.

\section{References}

1. Rawla, P. Epidemiology of Prostate Cancer. World J. Oncol. 2019, 10, 63-89. [CrossRef] [PubMed]

2. Uo, T.; Sprenger, C.C.; Plymate, S.R. Androgen Receptor Signaling and Metabolic and Cellular Plasticity During Progression to Castration Resistant Prostate Cancer. Front. Oncol. 2020, 10, 580617. [CrossRef]

3. Jasndeep, K.; Azhar, H.; Ayema, H.; Hassan, N.; Sundip, P. A Comprehensive Review of Pharmaceutical and Surgical Interventions of Prostate Cancer. Cureus 2020, 12, e11617.

4. Braglia, L.; Zavatti, M.; Vinceti, M.; Martelli, A.M.; Marmiroli, S. Deregulated PTEN/PI3K/AKT/mTOR signaling in prostate cancer: Still a potential druggable target? Biochim. Biophys. Acta-Mol. Cell Res. 2020, 1867, 118731. [CrossRef]

5. Park, S.; Kim, Y.S.; Kim, D.Y.; So, I.; Jeon, J.H. PI3K pathway in prostate cancer: All resistant roads lead to PI3K. Biochim. Biophys. Acta-Rev. Cancer 2018, 1870, 198-206. [CrossRef]

6. Shorning, B.Y.; Dass, M.S.; Smalley, M.J.; Pearson, H.B. The PI3K-AKT-mTOR pathway and prostate cancer: At the crossroads of AR, MAPK, and WNT signaling. Int. J. Mol. Sci. 2020, 21, 4507. [CrossRef] [PubMed]

7. Canesin, G.; Krzyzanowska, A.; Hellsten, R.; Bjartell, A. Cytokines and Janus kinase/signal transducer and activator of transcription signaling in prostate cancer: Overview and therapeutic opportunities. Curr. Opin. Endocr. Metab. Res. 2020, 10, 36-42. [CrossRef]

8. Guérin, O.; Fischel, J.L.; Ferrero, J.M.; Bozec, A.; Milano, G. EGFR targeting in hormone-refractory prostate cancer: Current appraisal and prospects for treatment. Pharmaceuticals 2010, 3, 2238-2247. [CrossRef]

9. Deep, G.; Panigrahia, G.K. Hypoxia-induced signaling promotes prostate cancer progression: Exosomes role as messenger of hypoxic response in tumor microenvironment. Crit. Rev. Oncog. 2015, 20, 419-434. [CrossRef]

10. Testa, U.; Castelli, G.; Pelosi, E. Cellular and Molecular Mechanisms Underlying Prostate Cancer Development: Therapeutic Implications. Medicines 2019, 6, 82. [CrossRef]

11. Khoury, G.A.; Baliban, R.C.; Floudas, C.A. Proteome-wide post-translational modification statistics: Frequency analysis and curation of the swiss-prot database. Sci. Rep. 2011, 1, 90. [CrossRef] [PubMed]

12. Oo, H.Z.; Seiler, R.; Black, P.C.; Daugaard, M. Post-translational modifications in bladder cancer: Expanding the tumor target repertoire. Urol. Oncol. Semin. Orig. Investig. 2020, 38, 858-866. [CrossRef] [PubMed]

13. Chen, L.; Liu, S.; Tao, Y. Regulating tumor suppressor genes: Post-translational modifications. Signal Transduct. Target. Ther. 2020, 5, 1-25. [CrossRef] [PubMed] 
14. Martín-Bernabé, A.; Balcells, C.; Tarragó-Celada, J.; Foguet, C.; Bourgoin-Voillard, S.; Seve, M.; Cascante, M. The importance of post-translational modifications in systems biology approaches to identify therapeutic targets in cancer metabolism. Curr. Opin. Syst. Biol. 2017, 3, 161-169. [CrossRef]

15. Qian, M.; Yan, F.; Yuan, T.; Yang, B.; He, Q.; Zhu, H. Targeting post-translational modification of transcription factors as cancer therapy. Drug Discov. Today 2020, 25, 1502-1512. [CrossRef] [PubMed]

16. Theivendran, S.; Tang, J.; Lei, C.; Yang, Y.; Song, H.; Gu, Z.; Wang, Y.; Yang, Y.; Jin, L.; Yu, C. Post translational modification-assisted cancer immunotherapy for effective breast cancer treatment. Chem. Sci. 2020. [CrossRef]

17. Zhao, Y.; Jensen, O.N. Modification-specific proteomics: Strategies for characterization of post-translational modifications using enrichment techniques. Proteomics 2009, 9, 4632-4641. [CrossRef]

18. Spoel, S.H. Orchestrating the proteome with post-translational modifications. J. Exp. Bot. 2018, 69, 4499-4503. [CrossRef]

19. Gao, Y.; Ha, Y.S.; Kwon, T.G.; Cho, Y.C.; Lee, S.; Lee, J.N. Characterization of Kinase Expression Related to Increased Migration of PC-3M Cells Using Global Comparative Phosphoproteome Analysis. Cancer Genom. Proteom. 2020, 17, 543-553. [CrossRef]

20. Nguyen, E.V.; Pereira, B.A.; Lawrence, M.G.; Ma, X.; Rebello, R.J.; Chan, H.; Niranjan, B.; Wu, Y.; Ellem, S.; Guan, X.; et al. Proteomic profiling of human prostate cancer-associated fibroblasts (caf) reveals loxl2-dependent regulation of the tumor microenvironment. Mol. Cell. Proteom. 2019, 18, 1410-1427. [CrossRef]

21. Lee, R.S.; Zhang, L.; Berger, A.; Lawrence, M.G.; Song, J.; Niranjan, B.; Davies, R.G.; Lister, N.L.; Sandhu, S.K.; Rubin, M.A.; et al. Characterization of the ERG-regulated Kinome in Prostate Cancer Identifies TNIK as a Potential Therapeutic Target. Neoplasia 2019, 21, 389-400. [CrossRef]

22. Drake, J.M.; Paull, E.O.; Graham, N.A.; Lee, J.K.; Smith, B.A.; Titz, B.; Stoyanova, T.; Faltermeier, C.M.; Uzunangelov, V.; Carlin, D.E.; et al. Phosphoproteome Integration Reveals Patient-Specific Networks in Prostate Cancer. Cell 2016, 166, 1041-1054. [CrossRef] [PubMed]

23. Zhao, H.; Pflug, B.R.; Lai, X.; Wang, M. Pyruvate dehydrogenase alpha 1 as a target of omega-3 polyunsaturated fatty acids in human prostate cancer through a global phosphoproteomic analysis. Proteomics 2016, 16, 2419-2431. [CrossRef]

24. Drake, J.M.; Graham, N.A.; Stoyanova, T.; Sedghi, A.; Goldstein, A.S.; Cai, H.; Smith, D.A.; Zhang, H.; Komisopoulou, E.; Huang, J.; et al. Oncogene-specific activation of tyrosine kinase networks during prostate cancer progression. Proc. Natl. Acad. Sci. USA 2012, 109, 1643-1648. [CrossRef]

25. Faltermeier, C.M.; Drake, J.M.; Clark, P.M.; Smith, B.A.; Zong, Y.; Volpe, C.; Mathis, C.; Morrissey, C.; Castor, B.; Huang, J.; et al. Functional screen identifies kinases driving prostate cancer visceral and bone metastasis. Proc. Natl. Acad. Sci. USA 2015, 113, E172-E181. [CrossRef] [PubMed]

26. Ino, Y.; Arakawa, N.; Ishiguro, H.; Uemura, H.; Kubota, Y.; Hirano, H.; Toda, T. Phosphoproteome analysis demonstrates the potential role of THRAP3 phosphorylation in androgen-independent prostate cancer cell growth. Proteomics 2016, 16, 1069-1078. [CrossRef]

27. Jiang, N.; Hjorth-Jensen, K.; Hekmat, O.; Iglesias-Gato, D.; Kruse, T.; Wang, C.; Wei, W.; Ke, B.; Yan, B.; Niu, Y.; et al. In vivo quantitative phosphoproteomic profiling identifies novel regulators of castration-resistant prostate cancer growth. Oncogene 2015. [CrossRef]

28. Toughiri, R.; Li, X.; Du, Q.; Bieberich, C.J. Phosphorylation of NuMA by Aurora-A kinase in PC-3 prostate cancer cells affects proliferation, survival, and interphase NuMA localization. J. Cell. Biochem. 2013, 114, 823-830. [CrossRef]

29. Lee, B.Y.; Hochgräfe, F.; Lin, H.M.; Castillo, L.; Wu, J.; Raftery, M.J.; Martin Shreeve, S.; Horvath, L.G.; Daly, R.J. Phosphoproteomic profiling identifies focal adhesion kinase as a mediator of docetaxel resistance in castrate-resistant prostate cancer. Mol. Cancer Ther. 2013, 13, 190-201. [CrossRef]

30. Bai, R.; Luan, X.; Zhang, Y.; Robbe-Masselot, C.; Brockhausen, I.; Gao, Y. The expression and functional analysis of the sialyl-T antigen in prostate cancer. Glycoconj. J. 2020, 37, 423-433. [CrossRef] [PubMed]

31. Höti, N.; Lih, T.S.; Pan, J.; Zhou, Y.; Yang, G.; Deng, A.; Chen, L.; Dong, M.; Yang, R.B.; Tu, C.F.; et al. A Comprehensive analysis of fut8 overexpressing prostate cancer cells reveals the role of egfr in castration resistance. Cancers 2020, 12, 468. [CrossRef]

32. Clark, D.J.; Schnaubelt, M.; Hoti, N.; Hu, Y.; Zhou, Y.; Gooya, M.; Zhang, H. Impact of Increased FUT8 Expression on the Extracellular Vesicle Proteome in Prostate Cancer Cells. J. Proteome Res. 2020, 19, 2195-2205. [CrossRef] [PubMed]

33. Itkonen, H.M.; Urbanucci, A.; Martin, S.E.S.; Khan, A.; Mathelier, A.; Thiede, B.; Walker, S.; Mills, I.G. High OGT activity is essential for MYC-driven proliferation of prostate cancer cells. Theranostics 2019, 9, 2183-2197. [CrossRef] [PubMed]

34. Höti, N.; Yang, S.; Hu, Y.; Shah, P.; Haffner, M.C.; Zhang, H. Overexpression of $\alpha(1,6)$ fucosyltransferase in the development of castration-resistant prostate cancer cells. Prostate Cancer Prostatic Dis. 2018, 21, 137-146. [CrossRef] [PubMed]

35. Li, F.; Glinskii, O.V.; Mooney, B.P.; Rittenhouse-Olson, K.; Pienta, K.J.; Glinsky, V.V. Cell surface Thomsen-Friedenreich proteome profiling of metastatic prostate cancer cells reveals potential link with cancer stem cell-like phenotype. Oncotarget 2017, 8, 98598-98608. [CrossRef]

36. McCann, J.J.; Vasilevskaya, I.A.; Neupane, N.P.; Shafi, A.A.; McNair, C.; Dylgjeri, E.; Mandigo, A.C.; Schiewer, M.J.; Schrecengost, R.S.; Gallagher, P.; et al. USP22 functions as an oncogenic driver in prostate cancer by regulating cell proliferation and DNA repair. Cancer Res. 2020, 80, 430-443. [CrossRef]

37. Gulati, T.; Huang, C.; Caramia, F.; Raghu, D.; Paul, P.J.; Goode, R.J.A.; Keam, S.P.; Williams, S.G.; Haupt, S.; Kleifeld, O.; et al. Proteotranscriptomic Measurements of E6-Associated Protein (E6AP) Targets in DU145 Prostate Cancer Cells. Mol. Cell. Proteom. 2018, 17, 1170-1183. [CrossRef] 
38. Theurillat, J.P.P.; Udeshi, N.D.; Errington, W.J.; Svinkina, T.; Baca, S.C.; Pop, M.; Wild, P.J.; Blattner, M.; Groner, A.C.; Rubin, M.A.; et al. Ubiquitylome analysis identifies dysregulation of effector substrates in SPOP-mutant prostate cancer. Science (80-) 2014, 346, 85-89. [CrossRef]

39. Wen, D.; Xu, Z.; Xia, L.; Liu, X.; Tu, Y.; Lei, H.; Wang, W.; Wang, T.; Song, L.; Ma, C.; et al. Important role of SUMOylation of spliceosome factors in prostate cancer cells. J. Proteome Res. 2014, 13, 3571-3582. [CrossRef] [PubMed]

40. Mariscal, J.; Vagner, T.; Kim, M.; Zhou, B.; Chin, A.; Zandian, M.; Freeman, M.R.; You, S.; Zijlstra, A.; Yang, W.; et al. Comprehensive palmitoyl-proteomic analysis identifies distinct protein signatures for large and small cancer-derived extracellular vesicles. J. Extracell. Vesicles 2020, 9. [CrossRef]

41. Sharma, C.; Yang, W.; Steen, H.; Freeman, M.R.; Hemler, M.E. Antioxidant functions of DHHC3 suppress anti-cancer drug activities. Cell. Mol. Life Sci. 2020, 1-13. [CrossRef]

42. Cui, L.; Liu, M.; Lai, S.; Hou, H.; Diao, T.; Zhang, D.; Wang, M.; Zhang, Y.; Wang, J. Androgen upregulates the palmitoylation of eIF3L in human prostate LNCaP cells. OncoTargets Ther. 2019, 12, 4451-4459. [CrossRef]

43. Li, W.; Zhang, J.; Zou, L.; Cui, J.; Su, F.; Jin, J.; Xiao, F.; Liu, M.; Zhao, G. Palmitoylome profiling indicates that androgens regulate the palmitoylation of $\alpha$-tubulin in prostate cancer-derived LNCaP cells and supernatants. Oncol. Rep. 2019. [CrossRef]

44. Venkadakrishnan, V.B.; Ben-Salem, S.; Heemers, H.V. AR-dependent phosphorylation and phospho-proteome targets in prostate cancer. Endocr. Relat. Cancer 2020, 27, R193-R210. [CrossRef]

45. Shah, K.; Bradbury, N.A.; Franklin, R.; Chicago, N. Kinase Modulation of Androgen Receptor Signaling: Implications for Prostate Cancer. Cancer Cell Microenviron. 2015, 2, 2. [CrossRef]

46. Koryakina, Y.; Ta, H.Q.; Gioeli, D. Androgen receptor phosphorylation: Biological context and functional consequences. Endocr. Relat. Cancer 2014, 21, T131-T145. [CrossRef]

47. Liu, Y.L.; Horning, A.M.; Lieberman, B.; Kim, M.; Lin, C.K.; Hung, C.N.; Chou, C.W.; Wang, C.M.; Lin, C.L.; Kirma, N.B.; et al Spatial EGFR Dynamics and Metastatic Phenotypes Modulated by Upregulated EphB2 and Src Pathways in Advanced Prostate Cancer. Cancers 2019, 11, 1910. [CrossRef]

48. Wang, C.; Ke, Y.; Liu, S.; Pan, S.; Liu, Z.; Zhang, H.; Fan, Z.; Zhou, C.; Liu, J.; Wang, F. Ectopic fibroblast growth factor receptor 1 promotes inflammation by promoting nuclear factor-kB signaling in prostate cancer cells. J. Biol. Chem. 2018, 293, 14839-14849. [CrossRef] [PubMed]

49. Feng, S.; Wang, F.; Matsubara, A.; Kan, M.; McKeehan, W.L. Fibroblast growth factor receptor 2 limits and receptor 1 accelerates tumorigenicity of prostate epithelial cells. Cancer Res. 1997, 57, 5369-5378. [PubMed]

50. Teishima, J.; Hayashi, T.; Nagamatsu, H.; Shoji, K.; Shikuma, H.; Yamanaka, R.; Sekino, Y.; Goto, K.; Inoue, S.; Matsubara, A Fibroblast Growth Factor Family in the Progression of Prostate Cancer. J. Clin. Med. 2019, 8, 183. [CrossRef] [PubMed]

51. Wang, C.; Liu, Z.; Ke, Y.; Wang, F. Intrinsic FGFR2 and ectopic FGFR1 signaling in the prostate and prostate cancer. Front. Genet. 2019, 10. [CrossRef]

52. Wang, J.; Yu, W.; Cai, Y.; Ren, C.; Ittmann, M.M. Altered fibroblast growth factor receptor 4 stability promotes prostate cancer progression. Neoplasia 2008, 10, 847-856. [CrossRef] [PubMed]

53. Sugiyama, N.; Varjosalo, M.; Meller, P.; Lohi, J.; Hyytiäinen, M.; Kilpinen, S.; Kallioniemi, O.; Ingvarsen, S.; Engelholm, L.H.; Taipale, J.; et al. fibroblast growth factor receptor 4 regulates tumor invasion by coupling fibroblast growth factor signaling to extracellular matrix degradation. Cancer Res. 2010, 70, 7851-7861. [CrossRef]

54. Kawada, M.; Inoue, H.; Masuda, T.; Ikeda, D. Insulin-like growth factor i secreted from prostate stromal cells mediates tumorstromal cell interactions of prostate cancer. Cancer Res. 2006, 66, 4419-4425. [CrossRef]

55. Fan, W.Q.; Yanase, T.; Morinaga, H.; Okabe, T.; Nomura, M.; Daitoku, H.; Fukamizu, A.; Kato, S.; Takayanagi, R.; Nawata, H. Insulin-like growth factor 1/insulin signaling activates androgen signaling through direct interactions of Foxo1 with androgen receptor. J. Biol. Chem. 2007, 282, 7329-7338. [CrossRef]

56. Dayyani, F.; Parikh, N.U.; Varkaris, A.S.; Song, J.H.; Moorthy, S.; Chatterji, T.; Maity, S.N.; Wolfe, A.R.; Carboni, J.M.; Gottardis, M.M.; et al. Combined Inhibition Of IGF-1R/IR And Src Family Kinases Enhances Antitumor Effects In Prostate Cancer By Decreasing Activated Survival Pathways. PLoS ONE 2012, 7, e51189. [CrossRef] [PubMed]

57. Fahrenholtz, C.D.; Beltran, P.J.; Burnstein, K.L. Targeting IGF-IR with ganitumab inhibits tumorigenesis and increases durability of response to androgen-deprivation therapy in VCaP prostate cancer xenografts. Mol. Cancer Ther. 2013, 12, 394-404. [CrossRef]

58. Maslova, K.; Kyriakakis, E.; Pfaff, D.; Frachet, A.; Frismantiene, A.; Bubendorf, L.; Ruiz, C.; Vlajnic, T.; Erne, P.; Resink, T.J.; et al. EGFR and IGF-1R in regulation of prostate cancer cell phenotype and polarity: Opposing functions and modulation by T-cadherin. FASEB J. 2014, 29, 494-507. [CrossRef] [PubMed]

59. Chinni, S.R.; Sivalogan, S.; Dong, Z.; Trindade Filho, J.C.; Deng, X.; Bonfil, R.D.; Cher, M.L. CXCL12/CXCR4 signaling activates Akt-1 and MMP-9 expression in prostate cancer cells: The role of bone microenvironment-associated CXCL. Prostate 2006, 66, 32-48. [CrossRef]

60. Chinni, S.R.; Yamamoto, H.; Dong, Z.; Sabbota, A.; Bonfil, R.D.; Cher, M.L. CXCL12/CXCR4 transactivates her2 in lipid rafts of prostate cancer cells and promotes growth of metastatic deposits in bone. Mol. Cancer Res. 2008, 6, 446-457. [CrossRef] [PubMed]

61. Chetram, M.A.; Odero-Marah, V.; Hinton, C.V. Loss of PTEN Permits CXCR4-Mediated Tumorigenesis through ERK1/2 in Prostate Cancer Cells. Mol. Cancer Res. 2011, 9, 90-102. [CrossRef]

62. Kasina, S.; Macoska, J.A. The CXCL12/CXCR4 axis promotes ligand-independent activation of the androgen receptor. Mol. Cell. Endocrinol. 2012, 351, 249-263. [CrossRef] 
63. Cho, K.S.; Yoon, S.J.; Lee, J.Y.; Cho, N.H.; Choi, Y.D.; Song, Y.S.; Hong, S.J. Inhibition of tumor growth and histopathological changes following treatment with a chemokine receptor CXCR4 antagonist in a prostate cancer xenograft model. Oncol. Lett. 2013, 6, 933-938. [CrossRef]

64. Bhardwaj, A.; Srivastava, S.K.; Singh, S.; Arora, S.; Tyagi, N.; Andrews, J.; McClellan, S.; Carter, J.E.; Singh, A.P. CXCL12/CXCR4 signaling counteracts docetaxel-induced microtubule stabilization via p21-activated kinase 4-dependent activation of LIM domain kinase. Oncotarget 2014, 5, 11490-11500. [CrossRef]

65. Begley, L.A.; Kasina, S.; Shah, R.B.; Macoska, J.A. Signaling mechanisms coupled to CXCL12/CXCR4-mediated cellular proliferation are PTEN-dependent. Am. J. Clin. Exp. Urol. 2015, 3, 91-99.

66. Conley-LaComb, M.K.; Semaan, L.; Singareddy, R.; Li, Y.; Heath, E.I.; Kim, S.; Cher, M.L.; Chinni, S.R. Pharmacological targeting of CXCL12/CXCR4 signaling in prostate cancer bone metastasis. Mol. Cancer 2016, 15, 1-13. [CrossRef] [PubMed]

67. Shamaladevi, N.; Lyn, D.A.; Escudero, D.O.; Lokeshwar, B.L. CXC receptor-1 silencing inhibits androgen-independent prostate cancer. Cancer Res. 2009, 69, 8265-8274. [CrossRef]

68. Singh, R.K.; Lokeshwar, B.L. The IL-8-regulated chemokine receptor CXCR7 stimulates EGFR signaling to promote prostate cancer growth. Cancer Res. 2011, 71, 3268-3277. [CrossRef] [PubMed]

69. Sbrissa, D.; Semaan, L.; Govindarajan, B.; Li, Y.; Caruthers, N.J.; Stemmer, P.M.; Cher, M.L.; Sethi, S.; Vaishampayan, U.; Shisheva, A.; et al. A novel cross-talk between CXCR4 and PI4KIII $\alpha$ in prostate cancer cells. Oncogene 2018, 38, 332-344. [CrossRef]

70. Gioeli, D.; Mandell, J.W.; Petroni, G.R.; Frierson, H.F.; Weber, M.J. Activation of mitogen-activated protein kinase associated with prostate cancer progression. Cancer Res. 1999, 59, 279-284. [PubMed]

71. Hoshino, R.; Chatani, Y.; Yamori, T.; Tsuruo, T.; Oka, H.; Yoshida, O.; Shimada, Y.; Ari-I, S.; Wada, H.; Fujimoto, J.; et al. Constitutive activation of the 41-/43-kDa mitogen-activated protein kinase signaling pathway in human tumors. Oncogene 1999, 18, 813-822. [CrossRef] [PubMed]

72. Moro, L.; Arbini, A.A.; Marra, E.; Greco, M. Constitutive activation of MAPK/ERK inhibits prostate cancer cell proliferation through upregulation of BRCA. Int. J. Oncol. 2007, 30. [CrossRef]

73. Wang, W.; Shen, T.; Dong, B.; Creighton, C.J.; Meng, Y.; Zhou, W.; Shi, Q.; Zhou, H.; Zhang, Y.; Moore, D.D.; et al. MAPK4 overexpression promotes tumor progression via noncanonical activation of AKT/mTOR signaling. J. Clin. Investig. 2019, 129, 1015-1029. [CrossRef] [PubMed]

74. Xu, R.; Hu, J. The role of JNK in prostate cancer progression and therapeutic strategies. Biomed. Pharmacother. 2020, 121, 109679. [CrossRef] [PubMed]

75. Udhane, V.; Maranto, C.; Hoang, D.T.; Gu, L.; Erickson, A.; Devi, S.; Talati, P.G.; Banerjee, A.; Iczkowski, K.A.; Jacobsohn, K.; et al. Enzalutamide-induced feed-forward signaling loop promotes therapy-resistant prostate cancer growth providing an exploitable molecular target for JAK2 inhibitors. Mol. Cancer Ther. 2019, 19, 231-246. [CrossRef]

76. Xu, L.J.; Ma, Q.; Zhu, J.; Li, J.; Xue, B.X.; Gao, J.; Sun, C.Y.; Zang, Y.C.; Zhou, Y.B.; Yang, D.R.; et al. Combined inhibition of JAK1,2/Stat3-PD-L1 signaling pathway suppresses the immune escape of Castration-resistant prostate cancer to NK cells in Hypoxia. Mol. Med. Rep. 2018, 17, 8111-8120. [CrossRef]

77. Taddei, M.L.; Parri, M.; Angelucci, A.; Onnis, B.; Bianchini, F.; Giannoni, E.; Raugei, G.; Calorini, L.; Rucci, N.; Teti, A.; et al. Kinase-dependent and -independent roles of EphA2 in the regulation of prostate cancer invasion and metastasis. Am. J. Pathol. 2009, 174, 1492-1503. [CrossRef] [PubMed]

78. Gelman, I.H.; Peresie, J.; Eng, K.H.; Foster, B.A. Differential requirement for Src family tyrosine kinases in the initiation, progression, and metastasis of prostate cancer. Mol. Cancer Res. 2014, 12, 1470-1479. [CrossRef]

79. Slack, J.K.; Adams, R.B.; Rovin, J.D.; Bissonette, E.A.; Stoker, C.E.; Parsons, J.T. Alterations in the focal adhesion kinase/Src signal transduction pathway correlate with increased migratory capacity of prostate carcinoma cells. Oncogene 2001, 20, 1152-1163 [CrossRef]

80. Johnson, T.R.; Khandrika, L.; Kumar, B.; Venezia, S.; Koul, S.; Chandhoke, R.; Maroni, P.; Donohue, R.; Meacham, R.B.; Koul, H.K. Focal adhesion kinase controls aggressive phenotype of androgen-independent prostate cancer. Mol. Cancer Res. 2008, 6, 1639-1648. [CrossRef]

81. Guo, W.; Zhang, Z.; Li, G.; Lai, X.; Gu, R.; Xu, W.; Chen, H.; Xing, Z.; Chen, L.; Qian, J.; et al. Pyruvate Kinase M2 Promotes Prostate Cancer Metastasis Through Regulating ERK1/2-COX-2 Signaling. Front. Oncol. 2020, 10, 544288. [CrossRef]

82. Hu, Z.; Gupta, J.; Zhang, Z.; Gerseny, H.; Berg, A.; Chen, Y.J.; Zhang, Z.; Du, H.; Brendler, C.B.; Xiao, X.; et al. Systemic delivery of oncolytic adenoviruses targeting transforming growth factor- $\beta$ inhibits established bone metastasis in a prostate cancer mouse model. Hum. Gene Ther. 2012, 23, 871-882. [CrossRef] [PubMed]

83. Maolake, A.; Izumi, K.; Natsagdorj, A.; Iwamoto, H.; Kadomoto, S.; Makino, T.; Naito, R.; Shigehara, K.; Kadono, Y.; Hiratsuka, K.; et al. Tumor necrosis factor- $\alpha$ induces prostate cancer cell migration in lymphatic metastasis through CCR7 upregulation. Cancer Sci. 2018, 109, 1524-1531. [CrossRef]

84. Zhang, Y.; Zhang, J.; Lin, Y.; Lan, Y.; Lin, C.; Xuan, J.W.; Shen, M.M.; McKeehan, W.L.; Greenberg, N.M.; Wang, F. Role of epithelial cell fibroblast growth factor receptor substrate $2 \alpha$ in prostate development, regeneration and tumorigenesis. Development 2008, 135, 775-784. [CrossRef] [PubMed]

85. Liu, J.; You, P.; Chen, G.; Fu, X.; Zeng, X.; Wang, C.; Huang, Y.; An, L.; Wan, X.; Navone, N.; et al. Hyperactivated FRS2 $\alpha$-mediated signaling in prostate cancer cells promotes tumor angiogenesis and predicts poor clinical outcome of patients. Oncogene 2016, 35, 1750-1759. [CrossRef] 
86. Khan, M.I.; Johani, A.A.; Hamid, A.; Ateeq, B.; Manzar, N.; Adhami, V.M.; Lall, R.K.; Rath, S.; Sechi, M.; Siddiqui, I.A.; et al. Proproliferative function of adaptor protein GRB10 in prostate carcinoma. FASEB J. 2019, 33, 3198-3211. [CrossRef] [PubMed]

87. Hao, J.; Ci, X.; Wang, Y.; Choi, S.Y.C.; Sullivan, S.E.; Xue, H.; Wu, R.; Dong, X.; Haegert, A.M.; Collins, C.C.; et al. GRB10 sustains AR activity by interacting with PP2A in prostate cancer cells. Int. J. Cancer 2020. [CrossRef]

88. Nunes-Xavier, C.E.; Mingo, J.; López, J.I.; Pulido, R. The role of protein tyrosine phosphatases in prostate cancer biology. Biochim. Biophys. Acta-Mol. Cell Res. 2019, 1866, 102-113. [CrossRef] [PubMed]

89. Szklarczyk, D.; Franceschini, A.; Wyder, S.; Forslund, K.; Heller, D.; Huerta-Cepas, J.; Simonovic, M.; Roth, A.; Santos, A.; Tsafou, K.P.; et al. STRING v10: Protein-protein interaction networks, integrated over the tree of life. Nucleic Acids Res. 2015, 43, D447-D452. [CrossRef] [PubMed]

90. Shannon, P.; Markiel, A.; Ozier, O.; Baliga, N.S.; Wang, J.T.; Ramage, D.; Amin, N.; Schwikowski, B.; Ideker, T. Cytoscape: A software environment for integrated models of biomolecular interaction networks. Genome Res. 2003, 13, 2498-2504. [CrossRef]

91. Drake, J.M.; Graham, N.A.; Lee, J.K.; Stoyanova, T.; Faltermeier, C.M.; Sud, S.; Titz, B.; Huang, J.; Pienta, K.J.; Graeber, T.G.; et al. Metastatic castration-resistant prostate cancer reveals intrapatient similarity and interpatient heterogeneity of therapeutic kinase targets. Proc. Natl. Acad. Sci. USA 2013, 110, E4762-E4769. [CrossRef]

92. Lauc, G.; Krištić, J.; Zoldoš, V. Glycans-The third revolution in evolution. Front. Genet. 2014, 5, 145. [CrossRef]

93. Pinho, S.S.; Reis, C.A. Glycosylation in cancer: Mechanisms and clinical implications. Nat. Rev. Cancer 2015, 15, 540-555. [CrossRef] [PubMed]

94. Štambuk, T.; Klasić, M.; Zoldoš, V.; Lauc, G. N-glycans as functional effectors of genetic and epigenetic disease risk. Mol. Asp. Med. 2020, 100891. [CrossRef]

95. Vojta, A.; Samaržija, I.; Bočkor, L.; Zoldoš, V. Glyco-genes change expression in cancer through aberrant methylation. Biochim. et Biophys. Acta (BBA)-Gen. Subj. 2016, 1860, 1776-1785. [CrossRef] [PubMed]

96. Scott, E.; Munkley, J. Glycans as biomarkers in prostate cancer. Int. J. Mol. Sci. 2019, 20, 1389. [CrossRef]

97. Munkley, J.; Mills, I.G.; Elliott, D.J. The role of glycans in the development and progression of prostate cancer. Nat. Rev. Urol. 2016, 13, 324-333. [CrossRef] [PubMed]

98. Vajaria, B.N.; Patel, K.R.; Begum, R.; Patel, P.S. Sialylation: An Avenue to Target Cancer Cells. Pathol. Oncol. Res. 2016, $22,443-447$. [CrossRef] [PubMed]

99. Munkley, J.; Oltean, S.; Vodák, D.; Wilson, B.T.; Livermore, K.E.; Zhou, Y.; Star, E.; Floros, V.I.; Johannessen, B.; Knight, B.; et al. The androgen receptor controls expression of the cancer-associated sTn antigen and cell adhesion through induction of ST6GalNAc1 in prostate cancer. Oncotarget 2015, 6, 34358-34374. [CrossRef]

100. Kaushik, A.K.; Shojaie, A.; Panzitt, K.; Sonavane, R.; Venghatakrishnan, H.; Manikkam, M.; Zaslavsky, A.; Putluri, V.; Vasu, V.T.; Zhang, Y.; et al. Inhibition of the hexosamine biosynthetic pathway promotes castration-resistant prostate cancer. Nat. Commun. 2016, 7, 11612. [CrossRef]

101. Wei, A.; Fan, B.; Zhao, Y.; Zhang, H.; Wang, L.; Yu, X.; Yuan, Q.; Yang, D.; Wang, S. ST6Gal-I overexpression facilitates prostate cancer progression via the PI3K/Akt/GSK-3 $\beta / \beta$-catenin signaling pathway. Oncotarget 2016, 7, 65374-65388. [CrossRef]

102. Kalaydina, R.V.; Zhou, H.; Markvicheva, E.; Burov, S.V.; Zulkernine, F.; Szewczuk, M.R. Impact of fucosylation on self-assembly of prostate and breast tumor spheroids by using cyclo-rgdfk (Tpp) peptide and image object detection. OncoTargets Ther. 2019, 12, 11153-11173. [CrossRef] [PubMed]

103. Li, J.; Guillebon, A.D.; Hsu, J.W.; Barthel, S.R.; Dimitroff, C.J.; Lee, Y.F.; King, M.R. Human fucosyltransferase 6 enables prostate cancer metastasis to bone. Br. J. Cancer 2013, 109, 3014-3022. [CrossRef] [PubMed]

104. Tsui, K.H.; Chang, P.L.; Feng, T.H.; Chung, L.C.; Sung, H.C.; Juang, H.H. Evaluating the function of matriptase and N-acetylglucosaminyltransferase V in prostate cancer metastasis. Anticancer Res. 2008, 28, 1993-1999. [PubMed]

105. Munkley, J.; Vodak, D.; Livermore, K.E.; James, K.; Wilson, B.T.; Knight, B.; McCullagh, P.; McGrath, J.; Crundwell, M.; Harries, L.W.; et al. Glycosylation is an Androgen-Regulated Process Essential for Prostate Cancer Cell Viability. EBioMedicine 2016, 8, 103-116. [CrossRef] [PubMed]

106. Horak, P.; Tomasich, E.; Vaňhara, P.; Kratochvílová, K.; Anees, M.; Marhold, M.; Lemberger, C.E.; Gerschpacher, M.; Horvat, R.; Sibilia, M.; et al. TUSC3 Loss Alters the ER Stress Response and Accelerates Prostate Cancer Growth in vivo. Sci. Rep. 2014, 4, 3739. [CrossRef]

107. Itkonen, H.M.; Gorad, S.S.; Duveau, D.Y.; Martin, S.E.S.; Barkovskaya, A.; Bathen, T.F.; Moestue, S.A.; Mills, I.G. Inhibition of O-GlcNAc transferase activity reprograms prostate cancer cell metabolism. Oncotarget 2016, 7, 12464-12476. [CrossRef]

108. Tzeng, S.F.; Tsai, C.H.; Chao, T.K.; Chou, Y.C.; Yang, Y.C.; Tsai, M.H.; Cha, T.L.; Hsiao, P.W. O-Glycosylation-mediated signaling circuit drives metastatic castration-resistant prostate cancer. FASEB J. 2018, 32, 6869-6882. [CrossRef]

109. Tsai, C.H.; Tzeng, S.F.; Chao, T.K.; Tsai, C.Y.; Yang, Y.C.; Lee, M.T.; Hwang, J.J.; Chou, Y.C.; Tsai, M.H.; Cha, T.L.; et al. Metastatic progression of prostate cancer is mediated by autonomous binding of galectin-4-O-glycan to cancer cells. Cancer Res. 2016, 76, 5756-5767. [CrossRef]

110. Hagisawa, S.; Ohyama, C.; Takahashi, T.; Endoh, M.; Moriya, T.; Nakayama, J.; Arai, Y.; Fukuda, M. Expression of core 2 $\beta 1,6-\mathrm{N}$-acetylglucosaminyltransferase facilitates prostate cancer progression. Glycobiology 2005, 15, 1016-1024. [CrossRef] [PubMed] 
111. Sato, T.; Yoneyama, T.; Tobisawa, Y.; Hatakeyama, S.; Yamamoto, H.; Kojima, Y.; Mikami, J.; Mori, K.; Hashimoto, Y.; Koie, T.; et al. Core $2 \beta-1,6-\mathrm{N}$-acetylglucosaminyltransferase-1 expression in prostate biopsy specimen is an indicator of prostate cancer aggressiveness. Biochem. Biophys. Res. Commun. 2016, 470, 150-156. [CrossRef]

112. Okamoto, T.; Yoneyama, M.S.; Hatakeyama, S.; Mori, K.; Yamamoto, H.; Koie, T.; Saitoh, H.; Yamaya, K.; Funyu, T.; Fukuda, M.; et al. Core2 O-glycan-expressing prostate cancer cells are resistant to NK cell immunity. Mol. Med. Rep. 2013. [CrossRef] [PubMed]

113. Valenzuela, H.F.; Pace, K.E.; Cabrera, P.V.; White, R.; Porvari, K.; Kaija, H.; Vihko, P.; Baum, L.G. O-glycosylation regulates LNCaP prostate cancer cell susceptibility to apoptosis induced by galectin-1. Cancer Res. 2007, 67, 6155-6162. [CrossRef] [PubMed]

114. Lee, S.H.; Hatakeyama, S.; Yu, S.Y.; Bao, X.; Ohyama, C.; Khoo, K.H.; Fukuda, M.N.; Fukuda, M. Core3 O-glycan synthase suppresses tumor formation and metastasis of prostate carcinoma PC3 and LNCaP cells through down-regulation of $\alpha 2 \beta 1$ integrin complex. J. Biol. Chem. 2009, 284, 17157-17169. [CrossRef]

115. Mikami, J.; Tobisawa, Y.; Yoneyama, T.; Hatakeyama, S.; Mori, K.; Hashimoto, Y.; Koie, T.; Ohyama, C.; Fukuda, M. I-branching N -acetylglucosaminyltransferase regulates prostate cancer invasiveness by enhancing $\alpha 5 \beta 1$ integrin signaling. Cancer Sci. 2016. [CrossRef] [PubMed]

116. Edwards, I.J. Proteoglycans in prostate cancer. Nat. Rev. Urol. 2012, 9, 196-206. [CrossRef]

117. Martínez-Bosch, N.; Rodriguez-Vida, A.; Juanpere, N.; Lloreta, J.; Rovira, A.; Albanell, J.; Bellmunt, J.; Navarro, P. Galectins in prostate and bladder cancer: Tumorigenic roles and clinical opportunities. Nat. Rev. Urol. 2019, 16, 433-445. [CrossRef]

118. Dondoo, T.O.; Fukumori, T.; Daizumoto, K.; Fukawa, T.; Kohzuki, M.; Kowada, M.; Kusuhara, Y.; Mori, H.; Nakatsuji, H.; Takahashi, M.; et al. Galectin-3 is implicated in tumor progression and resistance to anti-androgen drug through regulation of androgen receptor signaling in prostate cancer. Anticancer Res. 2017, 37, 125-134. [CrossRef]

119. Nakajima, K.; Kho, D.H.; Yanagawa, T.; Harazono, Y.; Hogan, V.; Chen, W.; Ali-Fehmi, R.; Mehra, R.; Raz, A. Galectin-3 cleavage alters bone remodeling: Different outcomes in breast and prostate cancer skeletal metastasis. Cancer Res. 2016, 76, 1391-1402. [CrossRef]

120. Llop, E.; Ferrer-Batallé, M.; Barrabés, S.; Guerrero, P.E.; Ramírez, M.; Saldova, R.; Rudd, P.M.; Aleixandre, R.N.; Comet, J.; de Llorens, R.; et al. Improvement of Prostate Cancer Diagnosis by Detecting PSA Glycosylation-Specific Changes. Theranostics 2016, 6, 1190-1204. [CrossRef]

121. Ferrer-Batallé, M.; Llop, E.; Ramírez, M.; Aleixandre, R.N.; Saez, M.; Comet, J.; de Llorens, R.; Peracaula, R. Comparative study of blood-based biomarkers, $\alpha 2,3$-sialic acid PSA and PHI, for high-risk prostate cancer detection. Int. J. Mol. Sci. 2017, 18, 845. [CrossRef]

122. Chen, F.Z.; Zhao, X.K. Ubiquitin-proteasome pathway and prostate cancer. Oncol. Res. Treat. 2013, 36, 592-596. [CrossRef] [PubMed]

123. Voutsadakis, I.A.; Papandreou, C.N. The ubiquitin-proteasome system in prostate cancer and its transition to castration resistance. Urol. Oncol. Semin. Orig. Investig. 2012, 30, 752-761. [CrossRef]

124. Zheng, N.; Shabek, N. Ubiquitin ligases: Structure, function, and regulation. Annu. Rev. Biochem. 2017, 86, 129-157. [CrossRef]

125. Spratt, D.E.; Walden, H.; Shaw, G.S. RBR E3 ubiquitin ligases: New structures, new insights, new questions. Biochem. J. 2014, 458, 421-437. [CrossRef]

126. Metzger, M.B.; Hristova, V.A.; Weissman, A.M. HECT and RING finger families of E3 ubiquitin ligases at a glance. J. Cell Sci. 2012, 125, 531-537. [CrossRef]

127. Chen, Z.; Lu, W. Roles of ubiquitination and SUMOylation on prostate cancer: Mechanisms and clinical implications. Int. J. Mol. Sci. 2015, 16, 4560-4580. [CrossRef]

128. McClurg, U.L.; Robson, C.N. Deubiquitinating enzymes as oncotargets. Oncotarget 2015, 6, 9657-9668. [CrossRef] [PubMed]

129. Islam, M.T.; Zhou, X.; Chen, F.; Khan, M.A.; Fu, J.; Chen, H. Targeting the signalling pathways regulated by deubiquitinases for prostate cancer therapeutics. Cell Biochem. Funct. 2019, 37, 304-319. [CrossRef]

130. Clark, A.; Burleson, M. SPOP and cancer: A systematic review. Am. J. Cancer Res. 2020, 10, 704. [PubMed]

131. Wang, Z.; Song, Y.; Ye, M.; Dai, X.; Zhu, X.; Wei, W. The diverse roles of SPOP in prostate cancer and kidney cancer. Nat. Rev. Urol. 2020, 17, 339-350. [CrossRef]

132. Blattner, M.; Liu, D.; Robinson, B.D.; Huang, D.; Poliakov, A.; Gao, D.; Nataraj, S.; Deonarine, L.D.; Augello, M.A.; Sailer, V.; et al. SPOP Mutation Drives Prostate Tumorigenesis In Vivo through Coordinate Regulation of PI3K/mTOR and AR Signaling. Cancer Cell 2017, 31, 436-451. [CrossRef]

133. Qi, J.; Fan, L.; Hussain, A. Implications of ubiquitin ligases in castration-resistant prostate cancer. Curr. Opin. Oncol. 2015, 27, 172-176. [CrossRef] [PubMed]

134. Wen, S.; Niu, Y.; Huang, H. Posttranslational regulation of androgen dependent and independent androgen receptor activities in prostate cancer. Asian J. Urol. 2020, 7, 203-218. [CrossRef] [PubMed]

135. Zhu, S.; Zhao, D.; Yan, L.; Jiang, W.; Kim, J.S.; Gu, B.; Liu, Q.; Wang, R.; Xia, B.; Zhao, J.C.; et al. BMI1 regulates androgen receptor in prostate cancer independently of the polycomb repressive complex. Nat. Commun. 2018, 9, 1-13. [CrossRef]

136. Qi, J.; Nakayama, K.; Cardiff, R.D.; Borowsky, A.D.; Kaul, K.; Williams, R.; Krajewski, S.; Mercola, D.; Carpenter, P.M.; Bowtell, D.; et al. Siah2-Dependent Concerted Activity of HIF and FoxA2 Regulates Formation of Neuroendocrine Phenotype and Neuroendocrine Prostate Tumors. Cancer Cell 2010, 18, 23-38. [CrossRef] [PubMed] 
137. Qi, J.; Tripathi, M.; Mishra, R.; Sahgal, N.; Fazil, L.; Ettinger, S.; Placzek, W.J.; Claps, G.; Chung, L.W.K.; Bowtell, D.; et al. The E3 ubiquitin ligase siah2 contributes to castration-resistant prostate cancer by regulation of androgen receptor transcriptional activity. Cancer Cell 2013, 23, 332-346. [CrossRef]

138. Vatapalli, R.; Sagar, V.; Rodriguez, Y.; Zhao, J.C.; Unno, K.; Pamarthy, S.; Lysy, B.; Anker, J.; Han, H.; Yoo, Y.A.; et al. Histone methyltransferase DOT1L coordinates AR and MYC stability in prostate cancer. Nat. Commun. 2020, 11, 1-15. [CrossRef]

139. Li, B.; Lu, W.; Yang, Q.; Yu, X.; Matusik, R.J.; Chen, Z. Skp2 regulates androgen receptor through ubiquitin-mediated degradation independent of Akt/mTOR pathways in prostate cancer. Prostate 2013, 74, 421-432. [CrossRef]

140. Chang, K.H.; Li, R.; Kuri, B.; Lotan, Y.; Roehrborn, C.G.; Liu, J.; Vessella, R.; Nelson, P.S.; Kapur, P.; Guo, X.; et al. A gain-of-function mutation in dht synthesis in castration-resistant prostate cancer. Cell 2013, 154, 1074-1084. [CrossRef] [PubMed]

141. Song, M.S.; Carracedo, A.; Salmena, L.; Song, S.J.; Egia, A.; Malumbres, M.; Pandolfi, P.P. Nuclear PTEN regulates the APC-CDH1 tumor-suppressive complex in a phosphatase-independent manner. Cell 2011, 144, 187-199. [CrossRef]

142. Gao, D.; Inuzuka, H.; Tseng, A.; Wei, W. Akt finds its new path to regulate cell cycle through modulating Skp2 activity and its destruction by APC/Cdh1. Cell Div. 2009, 4, 1-8. [CrossRef] [PubMed]

143. Ue Luk, I.S.; Shrestha, R.; Xue, H.; Wang, Y.; Zhang, F.; Lin, D.; Haegert, A.; Wu, R.; Dong, X.; Collins, C.C.; et al. BIRC6 targeting as potential therapy for advanced, enzalutamide-resistant prostate cancer. Clin. Cancer Res. 2017. [CrossRef]

144. Low, C.G.; Luk, I.S.U.; Lin, D.; Fazli, L.; Yang, K.; Xu, Y.; Gleave, M.; Gout, P.W.; Wang, Y. BIRC6 Protein, an Inhibitor of Apoptosis: Role in Survival of Human Prostate Cancer Cells. PLoS ONE 2013, 8, e55837. [CrossRef]

145. Eigentler, A.; Tymoszuk, P.; Zwick, J.; Schmitz, A.A.; Pircher, A.; Kocher, F.; Schlicker, A.; Lesche, R.; Schäfer, G.; Theurl, I.; et al. The impact of Cand1 in prostate cancer. Cancers 2020, 12, 428. [CrossRef] [PubMed]

146. Korzeniewski, N.; Hohenfellner, M.; Duensing, S. CAND1 promotes PLK4-mediated centriole overduplication and is frequently disrupted in prostate cancer. Neoplasia 2012, 14, 799-806. [CrossRef] [PubMed]

147. Shrestha, N.; Shrestha, H.; Ryu, T.; Kim, H.; Simkhada, S.; Cho, Y.C.; Park, S.Y.; Cho, S.; Lee, K.Y.; Lee, J.H.; et al. $\delta$-Catenin Increases the Stability of EGFR by Decreasing c-Cbl Interaction and Enhances EGFR/Erk1/2 Signaling in Prostate Cancer. Mol. Cells 2018, 41, 320-330.

148. Dallavalle, C.; Albino, D.; Civenni, G.; Merulla, J.; Ostano, P.; Mello-Grand, M.; Rossi, S.; Losa, M.; D’Ambrosio, G.; Sessa, F.; et al MicroRNA-424 impairs ubiquitination to activate STAT3 and promote prostate tumor progression. J. Clin. Investig. 2016, 126, 4585-4602. [CrossRef] [PubMed]

149. Vitari, A.C.; Leong, K.G.; Newton, K.; Yee, C.; Oĝrourke, K.; Liu, J.; Phu, L.; Vij, R.; Ferrando, R.; Couto, S.S.; et al. COP1 is a tumour suppressor that causes degradation of ETS transcription factors. Nature 2011. [CrossRef]

150. Li, N.; Xue, W.; Yuan, H.; Dong, B.; Ding, Y.; Liu, Y.; Jiang, M.; Kan, S.; Sun, T.; Ren, J.; et al. AKT-mediated stabilization of histone methyltransferase WHSC1 promotes prostate cancer metastasis. J. Clin. Investig. 2017, 127, 1284-1302. [CrossRef]

151. Armenia, J.; Wankowicz, S.A.M.; Liu, D.; Gao, J.; Kundra, R.; Reznik, E.; Chatila, W.K.; Chakravarty, D.; Han, G.C.; Coleman, I.; et al. The long tail of oncogenic drivers in prostate cancer. Nat. Genet. 2018, 50, 645-651. [CrossRef] [PubMed]

152. Chen, H.H.; Fan, P.; Chang, S.W.; Tsao, Y.P.; Huang, H.P.; Chen, S.L. NRIP/DCAF6 stabilizes the androgen receptor protein by displacing DDB2 from the CUL4A-DDB1 E3 ligase complex in prostate cancer. Oncotarget 2017, 8, 21501-21515. [CrossRef] [PubMed]

153. Jiao, M.; Qi, M.; Zhang, F.; Hu, J.; Feng, T.; Zhao, M.; Li, X.; Liu, H.; Teng, W.; Zhang, J.; et al. CUL4B regulates cancer stem-like traits of prostate cancer cells by targeting BMI1 via miR200b/c. Prostate 2019, 79, 1294-1303. [CrossRef] [PubMed]

154. Zhao, M.; Qi, M.; Li, X.; Hu, J.; Zhang, J.; Jiao, M.; Bai, X.; Peng, X.; Han, B. CUL4B/miR-33b/C-MYC axis promotes prostate cancer progression. Prostate 2019, 79, 480-488. [CrossRef]

155. Kuchay, S.; Giorgi, C.; Simoneschi, D.; Pagan, J.; Missiroli, S.; Saraf, A.; Florens, L.; Washburn, M.P.; Collazo-Lorduy, A.; CastilloMartin, M.; et al. PTEN counteracts FBXL2 to promote IP3R3- and Ca2+-mediated apoptosis limiting tumour growth. Nature 2017, 546, 554-558. [CrossRef]

156. Stankiewicz, E.; Mao, X.; Mangham, D.C.; Xu, L.; Yeste-Velasco, M.; Fisher, G.; North, B.; Chaplin, T.; Young, B.; Wang, Y.; et al. Identification of FBXL4 as a Metastasis Associated Gene in Prostate Cancer. Sci. Rep. 2017, 7, 5124. [CrossRef]

157. Moro, L.; Simoneschi, D.; Kurz, E.; Arbini, A.A.; Jang, S.; Guaragnella, N.; Giannattasio, S.; Wang, W.; Chen, Y.A.; Pires, G.; et al. Epigenetic silencing of the ubiquitin ligase subunit FBXL7 impairs c-SRC degradation and promotes epithelial-to-mesenchymal transition and metastasis. Nat. Cell Biol. 2020, 1-13. [CrossRef]

158. Chen, X.; Sahasrabuddhe, A.A.; Szankasi, P.; Chung, F.; Basrur, V.; Rangnekar, V.M.; Pagano, M.; Lim, M.S.; Elenitoba-Johnson, K.S.J. Fbxo45-mediated degradation of the tumor-suppressor Par-4 regulates cancer cell survival. Cell Death Differ. 2014, 21, 1535-1545. [CrossRef]

159. Hebbar, N.; Burikhanov, R.; Shukla, N.; Qiu, S.; Zhao, Y.; Elenitoba-Johnson, K.S.J.; Rangnekar, V.M. A naturally generated decoy of the prostate apoptosis response-4 protein overcomes therapy resistance in tumors. Cancer Res. 2017, 77, 4039-4050. [CrossRef]

160. Li, Z.; Sun, Y.; Chen, X.; Squires, J.; Nowroozizadeh, B.; Liang, C.; Huang, J. P53 mutation directs AURKA overexpression via miR-25 and FBXW7 in prostatic small cell neuroendocrine carcinoma. Mol. Cancer Res. 2015, 13, 584-591. [CrossRef]

161. Hong, Z.; Zhang, W.; Ding, D.; Huang, Z.; Yan, Y.; Cao, W.; Pan, Y.; Hou, X.; Weroha, S.J.; Karnes, R.J.; et al. DNA Damage Promotes TMPRSS2-ERG Oncoprotein Destruction and Prostate Cancer Suppression via Signaling Converged by GSK3 $\beta$ and WEE. Mol. Cell 2020, 79, 1008-1023.e4. [CrossRef] 
162. Yuan, W.C.; Lee, Y.R.; Huang, S.F.; Lin, Y.M.; Chen, T.Y.; Chung, H.C.; Tsai, C.H.; Chen, H.Y.; Chiang, C.T.; Lai, C.K.; et al. A Cullin3-KLHL20 Ubiquitin Ligase-Dependent Pathway Targets PML to Potentiate HIF-1 Signaling and Prostate Cancer Progression. Cancer Cell 2011, 20, 214-228. [CrossRef]

163. Arai, S.; Varkaris, A.; Nouri, M.; Chen, S.; Xie, L.; Balk, S.P. March5 mediates noxa-dependent mcl1 degradation driven by kinase inhibitors and integrated stress response activation. eLife 2020, 9. [CrossRef]

164. Giridhar, P.V.; Williams, K.; VonHandorf, A.P.; Deford, P.L.; Kasper, S. Constant degradation of the androgen receptor by MDM2 conserves prostate cancer stem cell integrity. Cancer Res. 2019, 79, 1124-1137. [CrossRef]

165. Lin, H.K.; Wang, L.; Hu, Y.C.; Altuwaijri, S.; Chang, C. Phosphorylation-dependent ubiquitylation and degradation of androgen receptor by Akt require Mdm2 E3 ligase. EMBO J. 2002, 21, 4037-4048. [CrossRef] [PubMed]

166. Feng, F.Y.; Zhang, Y.; Kothari, V.; Evans, J.R.; Jackson, W.C.; Chen, W.; Johnson, S.B.; Luczak, C.; Wang, S.; Hamstra, D.A. MDM2 Inhibition Sensitizes Prostate Cancer Cells to Androgen Ablation and Radiotherapy in a p53-Dependent Manner. Neoplasia 2016, 18, 213-222. [CrossRef]

167. Kaczorowski, A.; Tolstov, Y.; Falkenstein, M.; Vasioukhin, V.; Prigge, E.S.; Geisler, C.; Kippenberger, M.; Nientiedt, C.; Ratz, L.; Kuryshev, V.; et al. Rearranged ERG confers robustness to prostate cancer cells by subverting the function of p53. Urol. Oncol. Semin. Orig. Investig. 2020, 38, 736.e1-736.e10. [CrossRef]

168. Zhang, Z.; Wang, H.; Li, M.; Rayburn, E.R.; Agrawal, S.; Zhang, R. Stabilization of E2F1 protein by MDM2 through the E2F1 ubiquitination pathway. Oncogene 2005, 24, 7238-7247. [CrossRef]

169. Li, Y.; Xie, N.; Gleave, M.E.; Rennie, P.S.; Dong, X. AR-v7 protein expression is regulated by protein kinase and phosphatase. Oncotarget 2015, 6, 33743-33754. [CrossRef]

170. Zhao, X.; Wang, Y.; He, J.; Deng, R.; Huang, X.; Guo, Y.; Li, L.; Xie, R.; Yu, J. LncRNA UCA1 maintains the low-tumorigenic and nonmetastatic status by stabilizing E-cadherin in primary prostate cancer cells. Mol. Carcinog. 2020. [CrossRef]

171. Chopra, H.; Khan, Z.; Contreras, J.; Wang, H.; Sedrak, A.; Zhu, Y. Activation of p53 and destabilization of androgen receptor by combinatorial inhibition of MDM2 and MDMX in prostate cancer cells. Oncotarget 2018. [CrossRef] [PubMed]

172. Ito, S.; Ueno, A.; Ueda, T.; Nakagawa, H.; Taniguchi, H.; Kayukawa, N.; Fujihara-Iwata, A.; Hongo, F.; Okihara, K.; Ukimura, O. CNPY2 inhibits MYLIP-mediated AR protein degradation in prostate cancer cells. Oncotarget 2018, 9, 17645-17655. [CrossRef] [PubMed]

173. Maruyama, S.; Miyajima, N.; Bohgaki, M.; Tsukiyama, T.; Shigemura, M.; Nonomura, K.; Hatakeyama, S. Ubiquitylation of $\varepsilon$-COP by PIRH2 and regulation of the secretion of PSA. Mol. Cell. Biochem. 2008. [CrossRef]

174. Logan, I.R.; Gaughan, L.; McCracken, S.R.C.; Sapountzi, V.; Leung, H.Y.; Robson, C.N. Human PIRH2 Enhances Androgen Receptor Signaling through Inhibition of Histone Deacetylase 1 and Is Overexpressed in Prostate Cancer. Mol. Cell. Biol. 2006, 26, 6502-6510. [CrossRef]

175. Wang, J.; Zhang, W.; Ji, W.; Liu, X.; Ouyang, G.; Xiao, W. The Von Hippel-Lindau protein suppresses androgen receptor activity. Mol. Endocrinol. 2014, 28, 239-248. [CrossRef]

176. Cook, K.M.; Kataria, N.; Martinez, C.A.; Kerr, B.; Zaiter, S.S.; Morgan, M.; McAlpine, S.R. C-terminal HSP90 inhibitors block the HIF-1 hypoxic response by degrading HIF-1 $\alpha$ through the oxygen-dependent degradation pathway. Cell. Physiol. Biochem. 2019, 53, 480-495. [CrossRef]

177. Wei, M.; Jiao, D.; Han, D.; Wu, J.; Wei, F.; Zheng, G.; Guo, Z.; Xi, W.; Yang, F.; Xie, P.; et al. Knockdown of RNF2 induces cell cycle arrest and apoptosis in prostate cancer cells through the upregulation of TXNIP. Oncotarget 2017. [CrossRef]

178. Su, W.; Han, H.H.; Wang, Y.; Zhang, B.; Zhou, B.; Cheng, Y.; Rumandla, A.; Gurrapu, S.; Chakraborty, G.; Su, J.; et al. The Polycomb Repressor Complex 1 Drives Double-Negative Prostate Cancer Metastasis by Coordinating Stemness and Immune Suppression. Cancer Cell 2019, 36, 139-155.e10. [CrossRef]

179. Xu, K.; Shimelis, H.; Linn, D.E.; Jiang, R.; Yang, X.; Sun, F.; Guo, Z.; Chen, H.; Li, W.; Chen, H.; et al. Regulation of Androgen Receptor Transcriptional Activity and Specificity by RNF6-Induced Ubiquitination. Cancer Cell 2009, 15, 270-282. [CrossRef] [PubMed]

180. Tan, M.; Xu, J.; Siddiqui, J.; Feng, F.; Sun, Y. Depletion of SAG/RBX2 E3 ubiquitin ligase suppresses prostate tumorigenesis via inactivation of the PI3K/AKT/mTOR axis. Mol. Cancer 2016, 15, 1-14. [CrossRef]

181. Xiao, Y.; Jiang, Y.; Song, H.; Liang, T.; Li, Y.; Yan, D.; Fu, Q.; Li, Z. RNF7 knockdown inhibits prostate cancer tumorigenesis by inactivation of ERK1/2 pathway. Sci. Rep. 2017, 7, 43683. [CrossRef]

182. Chen, C.; Zhou, Z.; Liu, R.; Li, Y.; Azmi, P.B.; Seth, A.K. The WW domain containing E3 ubiquitin protein ligase 1 upregulates ErbB2 and EGFR through RING finger protein. Oncogene 2008, 27, 6845-6855. [CrossRef]

183. Jääskeläinen, T.; Makkonen, H.; Visakorpi, T.; Kim, J.; Roeder, R.G.; Palvimo, J.J. Histone H2B ubiquitin ligases RNF20 and RNF40 in androgen signaling and prostate cancer cell growth. Mol. Cell. Endocrinol. 2012, 350, 87-98. [CrossRef]

184. Chen, L.; Siddiqui, S.; Bose, S.; Mooso, B.; Asuncion, A.; Bedolla, R.G.; Vinall, R.; Tepper, C.G.; Gandour-Edwards, R.; Shi, X.B.; et al. Nrdp1-mediated regulation of ErbB3 expression by the androgen receptor in androgen-dependent but not castrate-resistant prostate cancer cells. Cancer Res. 2010, 70, 5994-6003. [CrossRef]

185. Zhi, X.; Zhao, D.; Wang, Z.; Zhou, Z.; Wang, C.; Chen, W.; Liu, R.; Chen, C. E3 ubiquitin ligase RNF126 promotes cancer cell proliferation by targeting the tumor suppressor p21 for ubiquitin-mediated degradation. Cancer Res. 2013, 73, 385-394. [CrossRef]

186. Yu, X.; Ai, J.; Cai, L.; Jing, Y.; Wang, D.; Dong, J.; Pascal, L.E.; Zhang, J.; Luo, R.; Wang, Z. Regulation of tumor suppressor EAF2 polyubiquitination by ELL1 and SIAH2 in prostate cancer cells. Oncotarget 2016, 7, 29245-29254. [CrossRef] [PubMed] 
187. Liao, Y.; Liu, Y.; Xia, X.; Shao, Z.; Huang, C.; He, J.; Jiang, L.; Tang, D.; Liu, J.; Huang, H. Targeting GRP78-dependent AR-V7 protein degradation overcomes castration-resistance in prostate cancer therapy. Theranostics 2020, 10, 3366-3381. [CrossRef]

188. Ren, D.; Dai, Y.; Yang, Q.; Zhang, X.; Guo, W.; Ye, L.; Huang, S.; Chen, X.; Lai, Y.; Du, H.; et al. Wnt5a induces and maintains prostate cancer cells dormancy in bone. J. Exp. Med. 2018, 216, 428-449. [CrossRef] [PubMed]

189. Christian, P.A.; Fiandalo, M.V.; Schwarze, S.R. Possible role of death receptor-mediated apoptosis by the E3 ubiquitin ligases Siah2 and POSH. Mol. Cancer 2011, 10, 57. [CrossRef] [PubMed]

190. Lu, W.; Liu, S.; Li, B.; Xie, Y.; Izban, M.G.; Ballard, B.R.; Sathyanarayana, S.A.; Adunyah, S.E.; Matusik, R.J.; Chen, Z. SKP2 loss destabilizes EZH2 by promoting TRAF6-mediated ubiquitination to suppress prostate cancer. Oncogene 2017, 36, 1364-1373. [CrossRef] [PubMed]

191. Yang, Y.; Lu, Y.; Wang, L.; Mizokami, A.; Keller, E.T.; Zhang, J.; Fu, J. Skp2 is associated with paclitaxel resistance in prostate cancer cells. Oncol. Rep. 2016, 36, 559-566. [CrossRef] [PubMed]

192. Zhao, H.; Bauzon, F.; Fu, H.; Lu, Z.; Cui, J.; Nakayama, K.; Nakayama, K.I.; Locker, J.; Zhu, L. Skp2 Deletion Unmasks a p27 Safeguard that Blocks Tumorigenesis in the Absence of pRb and p53 Tumor Suppressors. Cancer Cell 2013, 24, 645-659. [CrossRef] [PubMed]

193. Shim, E.H.; Johnson, L.; Noh, H.L.; Kim, Y.J.; Sun, H.; Zeiss, C.; Zhang, H. Expression of the F-box protein SKP2 induces hyperplasia, dysplasia, and low-grade carcinoma in the mouse prostate. Cancer Res. 2003, 63, 1583-1588. [PubMed]

194. Lu, W.; Liu, S.; Li, B.; Xie, Y.; Adhiambo, C.; Yang, Q.; Ballard, B.R.; Nakayama, K.I.; Matusik, R.J.; Chen, Z. SKP2 inactivation suppresses prostate tumorigenesis by mediating JARID1B ubiquitination. Oncotarget 2015. [CrossRef]

195. Tsai, Y.S.; Lai, C.L.; Lai, C.H.; Chang, K.H.; Wu, K.; Tseng, S.F.; Fazli, L.; Gleave, M.; Xiao, G.; Gandee, L.; et al. The role of homeostatic regulation between tumor suppressor DAB2IP and oncogenic Skp2 in prostate cancer growth. Oncotarget 2014, 5, 6425-6436. [CrossRef]

196. Yang, W.L.; Jin, G.; Li, C.F.; Jeong, Y.S.; Moten, A.; Xu, D.; Feng, Z.; Chen, W.; Cai, Z.; Darnay, B.; et al. Cycles of ubiquitination and deubiquitination critically regulate growth factor-mediated activation of Akt signaling. Sci. Signal. 2013, 6, ra3. [CrossRef]

197. Arbini, A.A.; Guerra, F.; Greco, M.; Marra, E.; Gandee, L.; Xiao, G.; Lotan, Y.; Gasparre, G.; Hsieh, J.T.; Moro, L. Mitochondrial DNA depletion sensitizes cancer cells to PARP inhibitors by translational and post-translational repression of BRCA2. Oncogenesis 2013, 2, e82. [CrossRef]

198. Lin, H.K.; Chen, Z.; Wang, G.; Nardella, C.; Lee, S.W.; Chan, C.H.; Yang, W.L.; Wang, J.; Egia, A.; Nakayama, K.I.; et al. Skp2 targeting suppresses tumorigenesis by Arf-p53-independent cellular senescence. Nature 2010, 464, 374-379. [CrossRef] [PubMed]

199. Ruan, D.; He, J.; Li, C.F.; Lee, H.J.; Liu, J.; Lin, H.K.; Chan, C.H. Skp2 deficiency restricts the progression and stem cell features of castration-resistant prostate cancer by destabilizing Twist. Oncogene 2017, 36, 4299-4310. [CrossRef]

200. Liu, J.; Peng, Y.; Shi, L.; Wan, L.; Inuzuka, H.; Long, J.; Guo, J.; Zhang, J.; Yuan, M.; Zhang, S.; et al. Skp2 dictates cell cycle-dependent metabolic oscillation between glycolysis and TCA cycle. Cell Res. 2020. [CrossRef]

201. Wang, F.; Chan, C.H.; Chen, K.; Guan, X.; Lin, H.K.; Tong, Q. Deacetylation of FOXO3 by SIRT1 or SIRT2 leads to Skp2-mediated FOXO3 ubiquitination and degradation. Oncogene 2012. [CrossRef] [PubMed]

202. Inuzuka, H.; Gao, D.; Finley, L.W.S.; Yang, W.; Wan, L.; Fukushima, H.; Chin, Y.R.; Zhai, B.; Shaik, S.; Lau, A.W.; et al. Acetylation-dependent regulation of Skp2 function. Cell 2012, 150, 179-193. [CrossRef]

203. Šimečková, Š.; Kahounová, Z.; Fedr, R.; Remšík, J.; Slabáková, E.; Suchánková, T.; Procházková, J.; Bouchal, J.; Kharaishvili, G.; Král, M.; et al. High Skp2 expression is associated with a mesenchymal phenotype and increased tumorigenic potential of prostate cancer cells. Sci. Rep. 2019, 9, 5695. [CrossRef]

204. Das, R.; Gregory, P.A.; Fernandes, R.C.; Denis, I.; Wang, Q.; Townley, S.L.; Zhao, S.G.; Hanson, A.R.; Pickering, M.A.; Armstrong, H.K.; et al. MicroRNA-194 promotes prostate cancer metastasis by inhibiting SOCS2. Cancer Res. 2017, 77, 1021-1034. [CrossRef] [PubMed]

205. Paul, I.; Batth, T.S.; Iglesias-Gato, D.; Al-Araimi, A.; Al-Haddabi, I.; Alkharusi, A.; Norstedt, G.; Olsen, J.V.; Zadjali, F.; FloresMorales, A. The ubiquitin ligase Cullin5SOCS2 regulates NDR1/STK38 stability and NF-kB transactivation. Sci. Rep. 2017, 7, 42800. [CrossRef]

206. Guan, B.; Pungaliya, P.; Li, X.; Uquillas, C.; Mutton, L.N.; Rubin, E.H.; Bieberich, C.J. Ubiquitination by TOPORS regulates the prostate tumor suppressor NKX3. J. Biol. Chem. 2008, 283, 4834-4840. [CrossRef]

207. Singh, R.; Karri, D.; Shen, H.; Shao, J.; Dasgupta, S.; Huang, S.; Edwards, D.P.; Ittmann, M.M.; O’Malley, B.W.; Yi, P. TRAF4mediated ubiquitination of NGF receptor TrkA regulates prostate cancer metastasis. J. Clin. Investig. 2018, 128, $3129-3143$. [CrossRef] [PubMed]

208. Hamidi, A.; Song, J.; Thakur, N.; Itoh, S.; Marcusson, A.; Bergh, A.; Heldin, C.H.; Landström, M. TGF- $\beta$ promotes PI3K-AKT signaling and prostate cancer cell migration through the TRAF6-mediated ubiquitylation of p85 $\alpha$. Sci. Signal. 2017, 10, eaal4186. [CrossRef]

209. Sundar, R.; Gudey, S.K.; Heldin, C.H.; Landström, M. TRAF6 promotes TGF $\beta$-induced invasion and cell-cycle regulation via Lys63-linked polyubiquitination of Lys178 in TGF $\beta$ type I receptor. Cell Cycle 2015, 14, 554-565. [CrossRef] [PubMed]

210. Gudey, S.K.; Sundar, R.; Mu, Y.; Wallenius, A.; Zang, G.; Bergh, A.; Heldin, C.H.; Landström, M. TRAF6 stimulates the tumorpromoting effects of TGF $\beta$ type I receptor through polyubiquitination and activation of presenilin. Sci. Signal. 2014,7 , ra2. [CrossRef] [PubMed] 
211. Linares, J.F.; Duran, A.; Reina-Campos, M.; Aza-Blanc, P.; Campos, A.; Moscat, J.; Diaz-Meco, M.T. Amino Acid Activation of mTORC1 by a PB1-Domain-Driven Kinase Complex Cascade. Cell Rep. 2015, 12, 1339-1352. [CrossRef] [PubMed]

212. Hamidi, A.; Von Bulow, V.; Hamidi, R.; Winssinger, N.; Barluenga, S.; Heldin, C.H.; Landström, M. Polyubiquitination of transforming growth factor $\beta$ (TGF $\beta$ )- associated kinase 1 mediates nuclear factor- $\mathrm{kB}$ activation in response to different inflammatory stimuli. J. Biol. Chem. 2012, 287, 123-133. [CrossRef]

213. Pan, Y.; Zhang, R.; Chen, H.; Chen, W.; Wu, K.; Lv, J. Expression of tripartite motif-containing proteactiin 11 (TRIM11) is associated with the progression of human prostate cancer and is downregulated by microRNA-5193. Med Sci. Monit. 2019, 25, 98-106. [CrossRef]

214. Qi, L.; Lu, Z.; Sun, Y.H.; Song, H.T.; Xu, W.K. TRIM16 suppresses the progression of prostate tumors by inhibiting the Snail signaling pathway. Int. J. Mol. Med. 2016, 38, 1734-1742. [CrossRef] [PubMed]

215. Wang, S.; Kollipara, R.K.; Humphries, C.G.; Ma, S.H.; Hutchinson, R.; Li, R.; Siddiqui, J.; Tomlins, S.A.; Raj, G.V.; Kittler, R. The ubiquitin ligase TRIM25 targets ERG for degradation in prostate cancer. Oncotarget 2016, 7, 64921-64931. [CrossRef]

216. Takayama, K.I.; Suzuki, T.; Tanaka, T.; Fujimura, T.; Takahashi, S.; Urano, T.; Ikeda, K.; Inoue, S. TRIM25 enhances cell growth and cell survival by modulating p53 signals via interaction with G3BP2 in prostate cancer. Oncogene 2018, 37, 2165-2180. [CrossRef]

217. Cohen, M.; Amir, S.; Golan, M.; Ben-Neriah, Y.; Mabjeesh, N.J. $\beta$-TrCP upregulates HIF-1 in prostate cancer cells. Prostate 2019, 79, 403-413. [CrossRef]

218. Zhao, D.; Lu, X.; Wang, G.; Lan, Z.; Liao, W.; Li, J.; Liang, X.; Chen, J.R.; Shah, S.; Shang, X.; et al. Synthetic essentiality of chromatin remodelling factor CHD1 in PTEN-deficient cancer. Nat. Cell Biol. 2017, 542, 484-488. [CrossRef] [PubMed]

219. Zhong, J.; Shaik, S.; Wan, L.; Tron, A.E.; Wang, Z.; Sun, L.; Inuzuka, H.; Wei, W. SCF $\beta$-TRCP targets MTSS1 for ubiquitinationmediated destruction to regulate cancer cell proliferation and migration. Oncotarget 2013, 4, 2339-2353. [CrossRef] [PubMed]

220. Svensson, C.; Ceder, J.; Iglesias-Gato, D.; Chuan, Y.C.; Pang, S.T.; Bjartell, A.; Martinez, R.M.; Bott, L.; Helczynski, L.; Ulmert, D.; et al. REST mediates androgen receptor actions on gene repression and predicts early recurrence of prostate cancer. Nucleic Acids Res. 2014, 42, 999-1015. [CrossRef]

221. Shrestha, H.; Yuan, T.; He, Y.; Moon, P.G.; Shrestha, N.; Ryu, T.; Park, S.Y.; Cho, Y.C.; Lee, C.H.; Baek, M.C.; et al. Investigation of the molecular mechanism of $\delta$-catenin ubiquitination: Implication of $\beta$-TrCP-1 as a potential E3 ligase. Biochim. Biophys. Acta-Mol. Cell Res. 2016, 1863, 2311-2321. [CrossRef]

222. Gluschnaider, U.; Hidas, G.; Cojocaru, G.; Yutkin, V.; Ben-Neriah, Y.; Pikarsky, E. $\beta$-TrCP inhibition reduces prostate cancer cell growth via upregulation of the aryl hydrocarbon receptor. PLoS ONE 2010, 5, e9060. [CrossRef]

223. Bhatia, N.; Thiyagarajan, S.; Elcheva, I.; Saleem, M.; Dlugosz, A.; Mukhtar, H.; Spiegelman, V.S. Gli2 is targeted for ubiquitination and degradation by $\beta$-TrCP ubiquitin ligase. J. Biol. Chem. 2006, 281, 19320-19326. [CrossRef]

224. Wan, X.; Yang, S.; Huang, W.; Wu, D.; Chen, H.; Wu, M.; Li, J.; Li, T.; Li, Y. UHRF1 overexpression is involved in cell proliferation and biochemical recurrence in prostate cancer after radical prostatectomy. J. Exp. Clin. Cancer Res. 2016, 35, 34. [CrossRef] [PubMed]

225. Babbio, F.; Pistore, C.; Curti, L.; Castiglioni, I.; Kunderfranco, P.; Brino, L.; Oudet, P.; Seiler, R.; Thalman, G.N.; Roggero, E.; et al. The SRA protein UHRF1 promotes epigenetic crosstalks and is involved in prostate cancer progression. Oncogene 2012, 31, 4878-4887. [CrossRef]

226. Di Sante, G.; Pestell, T.G.; Casimiro, M.C.; Bisetto, S.; Powell, M.J.; Lisanti, M.P.; Cordon-Cardo, C.; Castillo-Martin, M.; Bonal, D.M.; Debattisti, V.; et al. Loss of sirt1 promotes prostatic intraepithelial neoplasia, reduces mitophagy, and delays park2 translocation to mitochondria. Am. J. Pathol. 2015, 185, 266-279. [CrossRef] [PubMed]

227. Xu, S.; Fan, L.; Jeon, H.Y.; Zhang, F.; Cui, X.; Mickle, M.B.; Peng, G.; Hussain, A.; Fazli, L.; Gleave, M.E.; et al. p300-Mediated Acetylation of Histone Demethylase JMJD1A Prevents Its Degradation by Ubiquitin Ligase STUB1 and Enhances Its Activity in Prostate Cancer. Cancer Res. 2020, 80, 3074-3087. [CrossRef]

228. Seo, J.H.; Agarwal, E.; Bryant, K.G.; Caino, M.C.; Kim, E.T.; Kossenkov, A.V.; Tang, H.Y.; Languino, L.R.; Gabrilovich, D.I.; Cohen, A.R.; et al. Syntaphilin ubiquitination regulates mitochondrial dynamics and tumor cell movements. Cancer Res. 2018, 78 , 4215-4228. [CrossRef] [PubMed]

229. Liu, C.; Lou, W.; Yang, J.C.; Liu, L.; Armstrong, C.M.; Lombard, A.P.; Zhao, R.; Noel, O.D.V.; Tepper, C.G.; Chen, H.W.; et al. Proteostasis by STUB1/HSP70 complex controls sensitivity to androgen receptor targeted therapy in advanced prostate cancer. Nat. Commun. 2018, 9, 1-16. [CrossRef]

230. Cheng, L.; Zang, J.; Dai, H.J.; Li, F.; Guo, F. Ubiquitin ligase CHIP functions as an oncogene and activates the AKT signaling pathway in prostate cancer. Int. J. Oncol. 2018, 53, 203-214. [CrossRef] [PubMed]

231. Wang, J.; Zhang, H.; Zhang, X.; Wang, P.; Wang, H.; Huang, F.; Zhou, C.; Zhou, J.; Li, S. PC-1 works in conjunction with E3 ligase CHIP to regulate androgen receptor stability and activity. Oncotarget 2016, 7, 81377-81388. [CrossRef] [PubMed]

232. Sarkar, S.; Brautigan, D.L.; Larner, J.M. Aurora kinase A promotes AR degradation via the E3 ligase CHIP. Mol. Cancer Res. 2017, 15, 1063-1072. [CrossRef] [PubMed]

233. Sarkar, S.; Brautigan, D.L.; Parsons, S.J.; Larner, J.M. Androgen receptor degradation by the E3 ligase CHIP modulates mitotic arrest in prostate cancer cells. Oncogene 2014, 33, 26-33. [CrossRef] [PubMed]

234. Biswas, K.; Sarkar, S.; Said, N.; Brautigan, D.L.; Larner, J.M. Aurora B Kinase Promotes CHIP-Dependent Degradation of HIF1 $\alpha$ in Prostate Cancer Cells. Mol. Cancer Ther. 2020. [CrossRef] [PubMed] 
235. Zhang, H.T.; Zeng, L.F.; He, Q.Y.; Tao, W.A.; Zha, Z.G.; Hu, C.D. The E3 ubiquitin ligase CHIP mediates ubiquitination and proteasomal degradation of PRMT5. Biochim. et Biophys. Acta (BBA)-Bioenerg. 2016, 1863, 335-346. [CrossRef] [PubMed]

236. Ahmed, S.F.; Deb, S.; Paul, I.; Chatterjee, A.; Mandal, T.; Chatterjee, U.; Ghosh, M.K. The chaperone-assisted E3 ligase C terminus of Hsc70-interacting protein (CHIP) targets PTEN for proteasomal degradation. J. Biol. Chem. 2012, 287, 15996-16006. [CrossRef]

237. Sun, Y.; Jia, X.; Gao, Q.; Liu, X.; Hou, L. The ubiquitin ligase UBE4A inhibits prostate cancer progression by targeting interleukinlike EMT inducer (ILEI). IUBMB Life 2017, 69, 16-21. [CrossRef]

238. Bian, P.; Dou, Z.; Jia, Z.; Li, W.; Pan, D. Activated Wnt/ $\beta$-Catenin signaling contributes to E3 ubiquitin ligase EDD-conferred docetaxel resistance in prostate cancer. Life Sci. 2020, 254, 116816. [CrossRef]

239. Gamell, C.; Bandilovska, I.; Gulati, T.; Kogan, A.; Lim, S.C.; Kovacevic, Z.; Takano, E.A.; Timpone, C.; Agupitan, A.D.; Litchfield, C.; et al. E6AP Promotes a Metastatic Phenotype in Prostate Cancer. iScience 2019, 22, 1-15. [CrossRef] [PubMed]

240. Raghu, D.; Paul, P.J.; Gulati, T.; Deb, S.; Khoo, C.; Russo, A.; Gallo, E.; Blandino, G.; Chan, A.L.; Takano, E.; et al. E6AP promotes prostate cancer by reducing p27 expression. Oncotarget 2017, 8, 42939-42948. [CrossRef] [PubMed]

241. Zhang, L.; Hu, X.; Chen, J.; Fu, G. Impact of E6-associated protein on the proliferation and invasion of prostate cancer cells in bone metastasis. Int. J. Clin. Exp. Pathol. 2015, 8, 6571-6575.

242. Srinivasan, S.; Nawaz, Z. E3 ubiquitin protein ligase, E6-associated protein (E6-AP) regulates PI3K-Akt signaling and prostate cell growth. Biochim. Biophys. Acta-Gene Regul. Mech. 2011, 1809, 119-127. [CrossRef] [PubMed]

243. Paul, P.J.; Raghu, D.; Chan, A.L.; Gulati, T.; Lambeth, L.; Takano, E.; Herold, M.J.; Hagekyriakou, J.; Vessella, R.L.; Fedele, C.; et al Restoration of tumor suppression in prostate cancer by targeting the E3 ligase E6AP. Oncogene 2016, 35, 6235-6245. [CrossRef]

244. Zhang, L.; Anglesio, M.S.; O'Sullivan, M.; Zhang, F.; Yang, G.; Sarao, R.; Nghiem, M.P.; Cronin, S.; Hara, H.; Melnyk, N.; et al. The E3 ligase HACE1 is a critical chromosome 6q21 tumor suppressor involved in multiple cancers. Nat. Med. 2007, 13, 1060-1069. [CrossRef]

245. Lee, H.J.; Li, C.F.; Ruan, D.; He, J.; Montal, E.D.; Lorenz, S.; Girnun, G.D.; Chan, C.H. Non-proteolytic ubiquitination of Hexokinase 2 by HectH9 controls tumor metabolism and cancer stem cell expansion. Nat. Commun. 2019, 10, 2625. [CrossRef] [PubMed]

246. Fan, L.; Peng, G.; Sahgal, N.; Fazli, L.; Gleave, M.; Zhang, Y.; Hussain, A.; Qi, J. Regulation of c-Myc expression by the histone demethylase JMJD1A is essential for prostate cancer cell growth and survival. Oncogene 2016, 35, 2441-2452. [CrossRef]

247. Qu, H.; Liu, H.; Jin, Y.; Cui, Z.; Han, G. HUWE1 upregulation has tumor suppressive effect in human prostate cancer cell lines through c-Myc. Biomed. Pharmacother. 2018, 106, 309-315. [CrossRef]

248. Le Clorennec, C.; Lazrek, Y.; Dubreuil, O.; Larbouret, C.; Poul, M.A.; Mondon, P.; Melino, G.; Pèlegrin, A.; Chardès, T. The antiHER3 (ErbB3) therapeutic antibody 9F7-F11 induces HER3 ubiquitination and degradation in tumors through JNK1/2-dependent ITCH/AIP4 activation. Oncotarget 2016, 7, 37013-37029. [CrossRef]

249. Fukushima, T.; Yoshihara, H.; Furuta, H.; Kamei, H.; Hakuno, F.; Luan, J.; Duan, C.; Saeki, Y.; Tanaka, K.; Iemura, S.I.; et al. Nedd4-induced monoubiquitination of IRS-2 enhances IGF signalling and mitogenic activity. Nat. Commun. 2015, 6, 6780. [CrossRef]

250. Li, H.; Xu, L.L.; Masuda, K.; Raymundo, E.; McLeod, D.G.; Dobi, A.; Srivastava, S. A feedback loop between the androgen receptor and a NEDD4-binding protein, PMEPA1, in prostate cancer cells. J. Biol. Chem. 2008, 283, 28988-28995. [CrossRef] [PubMed]

251. Huang, Z.; Choi, B.K.; Mujoo, K.; Fan, X.; Fa, M.; Mukherjee, S.; Owiti, N.; Zhang, N.; An, Z. The E3 ubiquitin ligase NEDD4 negatively regulates HER3/ErbB3 level and signaling. Oncogene 2014, 34, 1105-1115. [CrossRef]

252. Zhang, X.; Wang, D.; Liu, B.; Jin, X.; Wang, X.; Pan, J.; Tu, W.; Shao, Y. IMP3 accelerates the progression of prostate cancer through inhibiting PTEN expression in a SMURF1-dependent way. J. Exp. Clin. Cancer Res. 2020, 39, 1-12. [CrossRef]

253. Gang, X.; Wang, G.; Huang, H. Androgens regulate SMAD ubiquitination regulatory factor-1 expression and prostate cancer cell invasion. Prostate 2015, 75, 561-572. [CrossRef]

254. Chen, C.; Sun, X.; Guo, P.; Dong, X.Y.; Sethi, P.; Zhou, W.; Zhou, Z.; Petros, J.; Frierson, H.F.; Vessella, R.L.; et al. Ubiquitin E3 ligase WWP1 as an oncogenic factor in human prostate cancer. Oncogene 2007. [CrossRef]

255. Li, Y.; Zhou, Z.; Chen, C. WW domain-containing E3 ubiquitin protein ligase 1 targets p63 transcription factor for ubiquitinmediated proteasomal degradation and regulates apoptosis. Cell Death Differ. 2008, 15, 1941-1951. [CrossRef] [PubMed]

256. Chen, C.; Sun, X.; Guo, P.; Dong, X.Y.; Sethi, P.; Cheng, X.; Zhou, J.; Ling, J.; Simons, J.W.; Lingrel, J.B.; et al. Human Kruppel-like factor 5 is a target of the E3 ubiquitin ligase WWP1 for proteolysis in epithelial cells. J. Biol. Chem. 2005, 280, 41553-41561. [CrossRef]

257. Goto, Y.; Kojima, S.; Kurozumi, A.; Kato, M.; Okato, A.; Matsushita, R.; Ichikawa, T.; Seki, N. Regulation of E3 ubiquitin ligase-1 (WWP1) by microRNA-452 inhibits cancer cell migration and invasion in prostate cancer. Br. J. Cancer 2016, 114, 1135-1144. [CrossRef] [PubMed]

258. Bawa-Khalfe, T.; Yang, F.M.; Ritho, J.; Lin, H.K.; Cheng, J.; Yeh, E.T.H. SENP1 regulates PTEN stability to dictate prostate cancer development. Oncotarget 2017. [CrossRef]

259. Wen, M.; Kwon, Y.; Wang, Y.; Mao, J.H.; Wei, G. Elevated expression of UBE2T exhibits oncogenic properties in human prostate cancer. Oncotarget 2015, 6, 25226-25239. [CrossRef] [PubMed]

260. Vila, I.K.; Yao, Y.; Kim, G.; Xia, W.; Kim, H.; Kim, S.J.; Park, M.K.; Hwang, J.P.; González-Billalabeitia, E.; Hung, M.C.; et al. A UBE2O-AMPK $\alpha 2$ Axis that Promotes Tumor Initiation and Progression Offers Opportunities for Therapy. Cancer Cell 2017, 31, 208-224. [CrossRef] [PubMed] 
261. Vere, G.; Kealy, R.; Kessler, B.M.; Pinto-Fernandez, A. Ubiquitomics: An overview and future. Biomolecules 2020, $10,1453$. [CrossRef] [PubMed]

262. Stewart, M.D.; Ritterhoff, T.; Klevit, R.E.; Brzovic, P.S. E2 enzymes: More than just middle men. Cell Res. 2016, 26, 423-440. [CrossRef] [PubMed]

263. Vlachostergios, P.J.; Papandreou, C.N. The role of the small ubiquitin-related modifier (SUMO) pathway in prostate cancer. Biomolecules 2012, 2, 240-255. [CrossRef] [PubMed]

264. Cheng, J.; Bawa, T.; Lee, P.; Gong, L.; Yeh, E.T.H. Role of desumoylation in the development of prostate cancer. Neoplasia 2006, 8 , 667-676. [CrossRef]

265. Nishida, T.; Yasuda, H. PIAS1 and PIASx $\alpha$ function as SUMO-E3 ligases toward androgen receptor and repress androgen receptor-dependent transcription. J. Biol. Chem. 2002, 277, 41311-41317. [CrossRef]

266. Zheng, Z.; Cai, C.; Omwancha, J.; Chen, S.Y.; Baslan, T.; Shemshedini, L. SUMO-3 enhances androgen receptor transcriptional activity through a sumoylation-independent mechanism in prostate cancer cells. J. Biol. Chem. 2006, 281, 4002-4012. [CrossRef]

267. Yang, N.; Liu, S.; Qin, T.; Liu, X.; Watanabe, N.; Mayo, K.H.; Li, J.; Li, X. SUMO3 modification by PIAS1 modulates androgen receptor cellular distribution and stability. Cell Commun. Signal. 2019, 17, 1-16. [CrossRef]

268. Sutinen, P.; Malinen, M.; Heikkinen, S.; Palvimo, J.J. SUMOylation modulates the transcriptional activity of androgen receptor in a target gene and pathway selective manner. Nucleic Acids Res. 2014, 42, 8310-8319. [CrossRef]

269. Rytinki, M.; Kaikkonen, S.; Sutinen, P.; Paakinaho, V.; Rahkama, V.; Palvimo, J.J. Dynamic SUMOylation Is Linked to the Activity Cycles of Androgen Receptor in the Cell Nucleus. Mol. Cell. Biol. 2012, 32, 4195-4205. [CrossRef]

270. Mukherjee, S.; Cruz-Rodríguez, O.; Bolton, E.; Iñiguez-Lluhi, J.A. The in vivo role of androgen receptor SUMOylation as revealed by androgen insensitivity syndrome and prostate cancer mutations targeting the proline/glycine residues of synergy control motifs. J. Biol. Chem. 2012, 287, 31195-31206. [CrossRef]

271. Huang, J.; Yan, J.; Zhang, J.; Zhu, S.; Wang, Y.; Shi, T.; Zhu, C.; Chen, C.; Liu, X.; Cheng, J.; et al. SUMO1 modification of PTEN regulates tumorigenesis by controlling its association with the plasma membrane. Nat. Commun. 2012, 3, 911. [CrossRef]

272. Ashikari, D.; Takayama, K.; Tanaka, T.; Suzuki, Y.; Obinata, D.; Fujimura, T.; Urano, T.; Takahashi, S.; Inoue, S. Androgen induces G3BP2 and SUMO-mediated p53 nuclear export in prostate cancer. Oncogene 2017, 36, 6272-6281. [CrossRef] [PubMed]

273. Wang, C.M.; Yang, W.H. Loss of SUMOylation on ATF3 inhibits proliferation of prostate cancer cells by modulating CCND1/2 activity. Int. J. Mol. Sci. 2013, 14, 8367-8380. [CrossRef]

274. Sutinen, P.; Rahkama, V.; Rytinki, M.; Palvimo, J.J. Nuclear mobility and activity of FOXA1 with Androgen Receptor Are Regulated by SUMOylation. Mol. Endocrinol. 2014, 28, 1719-1728. [CrossRef]

275. Belaguli, N.S.; Zhang, M.; Brunicardi, F.C.; Berger, D.H. Forkhead Box Protein A2 (FOXA2) Protein Stability and Activity Are Regulated by Sumoylation. PLoS ONE 2012, 7, e48019. [CrossRef] [PubMed]

276. Luo, H.R.; Liu, Y.; Wan, X.D.; Li, J.L.; Wu, M.; Zhang, Q.M.; Wu, D.L.; Zhao, X.; Wang, T.R. Sumoylation Negatively Regulates CSR1-Dependent Prostate Cancer Cell Death. Cell. Physiol. Biochem. 2018, 46, 1861-1867. [CrossRef] [PubMed]

277. Park, S.Y.; Na, Y.; Lee, M.H.; Seo, J.S.; Lee, Y.H.; Choi, K.C.; Choi, H.K.; Yoon, H.G. SUMOylation of TBL1 and TBLR1 promotes androgen-independent prostate cancer cell growth. Oncotarget 2016, 7, 41110-41122. [CrossRef]

278. Choi, H.J.; Park, J.H.; Park, J.H.; Lee, K.B.; Oh, S.M. Pc2-mediated SUMOylation of WWOX is essential for its suppression of DU145 prostate tumorigenesis. FEBS Lett. 2015, 589, 3977-3988. [CrossRef] [PubMed]

279. Jung, H.K.; Ji, M.L.; Hye, J.N.; Hee, J.C.; Jung, W.Y.; Lee, J.S.; Mi, H.K.; Kim, S.-I.; Chin, H.C.; Keun, I.K.; et al. SUMOylation of pontin chromatin-remodeling complex reveals a signal integration code in prostate cancer cells. Proc. Natl. Acad. Sci. USA 2007, 104, 20793-20798. [CrossRef]

280. Xie, Y.; Liu, S.; Lu, W.; Yang, Q.; Williams, K.D.; Binhazim, A.A.; Carver, B.S.; Matusik, R.J.; Chen, Z. Slug regulates E-cadherin repression via p19Arf in prostate tumorigenesis. Mol. Oncol. 2014, 8, 1355-1364. [CrossRef]

281. Gudey, S.K.; Sundar, R.; Heldin, C.H.; Bergh, A.; Landström, M. Pro-invasive properties of Snail1 are regulated by sumoylation in response to TGF $\beta$ stimulation in cancer. Oncotarget 2017, 8, 97703-97726. [CrossRef]

282. Puhr, M.; Hoefer, J.; Neuwirt, H.; Eder, I.E.; Kern, J.; Schäfer, G.; Geley, S.; Heidegger, I.; Klocker, H.; Culig, Z. PIAS1 is a crucial factor for prostate cancer cell survival and a valid target in docetaxel resistant cells. Oncotarget 2014, 5, 12043-12056. [CrossRef]

283. Toropainen, S.; Malinen, M.; Kaikkonen, S.; Rytinki, M.; Jääskeläinen, T.; Sahu, B.; Jänne, O.A.; Palvimo, J.J. SUMO ligase PIAS1 functions as a target gene selective androgen receptor coregulator on prostate cancer cell chromatin. Nucleic Acids Res. 2015, 43, 848-861. [CrossRef]

284. Puhr, M.; Hoefer, J.; Eigentler, A.; Dietrich, D.; Van Leenders, G.; Uhl, B.; Hoogland, M.; Handle, F.; Schlick, B.; Neuwirt, H.; et al. PIAS1 is a determinant of poor survival and acts as a positive feedback regulator of AR signaling through enhanced AR stabilization in prostate cancer. Oncogene 2016. [CrossRef]

285. Kaikkonen, S.; Jääskeläinen, T.; Karvonen, U.; Rytinki, M.M.; Makkonen, H.; Gioeli, D.; Paschal, B.M.; Palvimo, J.J. SUMO-specific protease 1 (SENP1) reverses the hormone-augmented SUMOylation of androgen receptor and modulates gene responses in prostate cancer cells. Mol. Endocrinol. 2009, 23, 292-307. [CrossRef] [PubMed]

286. Zhang, X.; Wang, H.; Wang, H.; Xiao, F.; Seth, P.; Xu, W.; Jia, Q.; Wu, C.; Yang, Y.; Wang, L. SUMO-specific cysteine protease 1 promotes epithelial mesenchymal transition of prostate cancer cells via regulating SMAD4 deSUMOylation. Int. J. Mol. Sci. 2017, 18, 808. [CrossRef] [PubMed] 
287. Bawa-Khalfe, T.; Cheng, J.; Lin, S.H.; Ittmann, M.M.; Yeh, E.T.H. SENP1 induces prostatic intraepithelial neoplasia through multiple mechanisms. J. Biol. Chem. 2010, 285, 25859-25866. [CrossRef]

288. Wang, Q.; Xia, N.; Li, T.; Xu, Y.; Zou, Y.; Zuo, Y.; Fan, Q.; Bawa-Khalfe, T.; Yeh, E.T.H.; Cheng, J. SUMO-specific protease 1 promotes prostate cancer progression and metastasis. Oncogene 2013. [CrossRef]

289. Zhu, H.; Ren, S.; Bitler, B.G.; Aird, K.M.; Tu, Z.; Skordalakes, E.; Zhu, Y.; Yan, J.; Sun, Y.; Zhang, R. SPOP E3 Ubiquitin Ligase Adaptor Promotes Cellular Senescence by Degrading the SENP7 deSUMOylase. Cell Rep. 2015, 13, 1183-1193. [CrossRef] [PubMed]

290. Xia, C.; Tao, Y.; Li, M.; Che, T.; Qu, J. Protein acetylation and deacetylation: An important regulatory modification in gene transcription (Review). Exp. Ther. Med. 2020, 20, 2923-2940. [CrossRef] [PubMed]

291. Narita, T.; Weinert, B.T.; Choudhary, C. Functions and mechanisms of non-histone protein acetylation. Nat. Rev. Mol. Cell Biol. 2019, 20, 156-174. [CrossRef]

292. Drazic, A.; Myklebust, L.M.; Ree, R.; Arnesen, T. The world of protein acetylation. Biochim. Biophys. Acta-Proteins Proteomics. 2016, 1864, 1372-1401. [CrossRef] [PubMed]

293. Cang, S.; Xu, X.; Ma, Y.; Liu, D.; Chiao, J.W. Hypoacetylation, hypomethylation, and dephosphorylation of H2B histones and excessive histone deacetylase activity in DU-145 prostate cancer cells. J. Hematol. Oncol. 2016, 9, 3. [CrossRef]

294. Cang, S.; Feng, J.; Konno, S.; Han, L.; Liu, K.; Sharma, S.C.; Choudhury, M.; Chiao, J.W. Deficient histone acetylation and excessive deacetylase activity as epigenomic marks of prostate cancer cells. Int. J. Oncol. 2009, 35, 1417-1422. [CrossRef]

295. Seligson, D.B.; Horvath, S.; Shi, T.; Yu, H.; Tze, S.; Grunstein, M.; Kurdistani, S.K. Global histone modification patterns predict risk of prostate cancer recurrence. Nature 2005. [CrossRef] [PubMed]

296. Bianco-Miotto, T.; Chiam, K.; Buchanan, G.; Jindal, S.; Day, T.K.; Thomas, M.; Pickering, M.A.; O’Loughlin, M.A.; Ryan, N.K.; Raymond, W.A.; et al. Global levels of specific histone modifications and an epigenetic gene signature predict prostate cancer progression and development. Cancer Epidemiol. Biomark. Prev. 2010, 19, 2611-2622. [CrossRef] [PubMed]

297. Watson, J.A.; Watson, C.J.; McCrohan, A.M.; Woodfine, K.; Tosetto, M.; McDaid, J.; Gallagher, E.; Betts, D.; Baugh, J.; O’Sullivan, J.; et al. Generation of an epigenetic signature by chronic hypoxia in prostate cells. Hum. Mol. Genet. 2009, 18, 3594-3604. [CrossRef]

298. Valdés-Mora, F.; Gould, C.M.; Colino-Sanguino, Y.; Qu, W.; Song, J.Z.; Taylor, K.M.; Buske, F.A.; Statham, A.L.; Nair, S.S.; Armstrong, N.J.; et al. Acetylated histone variant H2A.Z is involved in the activation of neo-enhancers in prostate cancer. Nat. Commun. 2017, 8, 1-17. [CrossRef]

299. Pathak, R.; Philizaire, M.; Mujtaba, S. Dichotomy in the epigenetic mark lysine acetylation is critical for the proliferation of prostate cancer cells. Cancers 2015, 7, 1622-1642. [CrossRef]

300. Wen, S.; He, Y.; Wang, L.; Zhang, J.; Quan, C.; Niu, Y.; Huang, H. Aberrant activation of super enhancer and choline metabolism drive antiandrogen therapy resistance in prostate cancer. Oncogene 2020, 1-16. [CrossRef]

301. Takeda, D.Y.; Spisák, S.; Seo, J.H.; Bell, C.; O’Connor, E.; Korthauer, K.; Ribli, D.; Csabai, I.; Solymosi, N.; Szállási, Z.; et al. A Somatically Acquired Enhancer of the Androgen Receptor Is a Noncoding Driver in Advanced Prostate Cancer. Cell 2018, 174, 422-432.e13. [CrossRef]

302. Wang, Z.; Wang, Z.; Guo, J.; Li, Y.; Bavarva, J.H.; Qian, C.; Brahimi-Horn, M.C.; Tan, D.; Liu, W. Inactivation of androgen-induced regulator ARD1 inhibits androgen receptor acetylation and prostate tumorigenesis. Proc. Natl. Acad. Sci. USA 2012, 109, 3053-3058. [CrossRef] [PubMed]

303. DePaolo, J.S.; Wang, Z.; Guo, J.; Zhang, G.; Qian, C.; Zhang, H.; Zabaleta, J.; Liu, W. Acetylation of androgen receptor by ARD1 promotes dissociation from HSP90 complex and prostate tumorigenesis. Oncotarget 2016, 7, 71417-71428. [CrossRef]

304. Fu, M.; Rao, M.; Wang, C.; Sakamaki, T.; Wang, J.; Di Vizio, D.; Zhang, X.; Albanese, C.; Balk, S.; Chang, C.; et al. Acetylation of Androgen Receptor Enhances Coactivator Binding and Promotes Prostate Cancer Cell Growth. Mol. Cell. Biol. 2003, 23, 8563-8575. [CrossRef]

305. Jia, L.; Berman, B.P.; Jariwala, U.; Yan, X.; Cogan, J.P.; Walkers, A.; Chen, T.; Buchanan, G.; Frenkel, B.; Coetzee, G.A. Genomic androgen receptor-occupied regions with different functions, defined by histone acetylation, coregulators and transcriptional capacity. PLoS ONE 2008, 3, e3645. [CrossRef]

306. Urbanucci, A.; Barfeld, S.J.; Kytölä, V.; Itkonen, H.M.; Coleman, I.M.; Vodák, D.; Sjöblom, L.; Sheng, X.; Tolonen, T.; Minner, S.; et al. Androgen Receptor Deregulation Drives Bromodomain-Mediated Chromatin Alterations in Prostate Cancer. Cell Rep. 2017, 19, 2045-2059. [CrossRef]

307. Shao, G.; Liu, Y.; Ma, T.; Zhang, L.; Yuan, M.; Zhao, S. GCN5 inhibition prevents IL-6-induced prostate cancer metastases through PI3K/PTEN/Akt signaling by inactivating Egr-1. Biosci. Rep. 2018, 38. [CrossRef] [PubMed]

308. Wang, C.; Sun, H.; Zou, R.; Zhou, T.; Wang, S.; Sun, S.; Tong, C.; Luo, H.; Li, Y.; Li, Z.; et al. MDC1 functionally identified as an androgen receptor co-activator participates in suppression of prostate cancer. Nucleic Acids Res. 2015, 43, 4893-4908. [CrossRef]

309. Lv, L.; Li, D.; Zhao, D.; Lin, R.; Chu, Y.; Zhang, H.; Zha, Z.; Liu, Y.; Li, Z.; Xu, Y.; et al. Acetylation Targets the M2 Isoform of Pyruvate Kinase for Degradation through Chaperone-Mediated Autophagy and Promotes Tumor Growth. Mol. Cell 2011, 42, 719-730. [CrossRef]

310. Ding, L.; Chen, S.; Liu, P.; Pan, Y.; Zhong, J.; Regan, K.M.; Wang, L.; Yu, C.; Rizzardi, A.; Cheng, L.; et al. CBP loss cooperates with PTEN haploinsufficiency to drive prostate cancer: Implications for epigenetic therapy. Cancer Res. 2014, 74, 2050-2061. [CrossRef] [PubMed] 
311. Liu, J.; He, D.; Cheng, L.; Huang, C.; Zhang, Y.; Rao, X.; Kong, Y.; Li, C.; Zhang, Z.; Liu, J.; et al. p300/CBP inhibition enhances the efficacy of programmed death-ligand 1 blockade treatment in prostate cancer. Oncogene 2020, 39, 3939-3951. [CrossRef]

312. Jin, L.; Garcia, J.; Chan, E.; De La Cruz, C.; Segal, E.; Merchant, M.; Kharbanda, S.; Raisner, R.; Haverty, P.M.; Modrusan, Z.; et al. Therapeutic targeting of the CBP/p300 bromodomain blocks the growth of castration-resistant prostate cancer. Cancer Res. 2017, 77, 5564-5575. [CrossRef]

313. Gang, X.; Yang, Y.; Zhong, J.; Jiang, K.; Pan, Y.; Jeffrey Karnes, R.; Zhang, J.; Xu, W.; Wang, G.; Huang, H. P300 acetyltransferase regulates fatty acid synthase expression, lipid metabolism and prostate cancer growth. Oncotarget 2016, 7, 15135-15149. [CrossRef]

314. Zhong, J.; Ding, L.; Bohrer, L.R.; Pan, Y.; Liu, P.; Zhang, J.; Sebo, T.J.; Karnes, R.J.; Tindall, D.J.; Van Deursen, J.; et al. P300 acetyltransferase regulates androgen receptor degradation and pten-deficient prostate tumorigenesis. Cancer Res. 2014, 74, 1870-1880. [CrossRef]

315. Knowell, A.E.; Patel, D.; Morton, D.J.; Sharma, P.; Glymph, S.; Chaudhary, J. Id4 dependent acetylation restores mutant-p53 transcriptional activity. Mol. Cancer 2013, 12, 161. [CrossRef] [PubMed]

316. Ianculescu, I.; Wu, D.Y.; Siegmund, K.D.; Stallcup, M.R. Selective roles for cAMP response element-binding protein binding protein and p300 protein as coregulators for androgen-regulated gene expression in advanced prostate cancer cells. J. Biol. Chem. 2012, 287, 4000-4013. [CrossRef] [PubMed]

317. Santer, F.R.; Höschele, P.P.S.; Su, J.O.; Erb, H.H.H.; Bouchal, J.; Cavarretta, I.T.; Parson, W.; Meyers, D.J.; Cole, P.A.; Culig, Z. Inhibition of the acetyltransferases p300 and CBP reveals a targetable function for p300 in the survival and invasion pathways of prostate cancer cell lines. Mol. Cancer Ther. 2011, 10, 1644-1655. [CrossRef]

318. Bouchal, J.; Santer, F.R.; Höschele, P.P.S.; Tomastikova, E.; Neuwirt, H.; Culig, Z. Transcriptional coactivators p300 and CBP stimulate estrogen receptor-beta signaling and regulate cellular events in prostate cancer. Prostate 2011. [CrossRef] [PubMed]

319. Lee, S.O.; Chun, J.Y.; Nadiminty, N.; Lou, W.; Feng, S.; Gao, A.C. Interleukin-4 activates androgen receptor through CBP/p. Prostate 2009, 69, 126-132. [CrossRef]

320. Heemers, H.V.; Debes, J.D.; Tindall, D.J. The role of the transcriptional coactivator $\mathrm{p} 300$ in prostate cancer progression. Adv. Exp. Med. Biol. 2008, 617, 535-540. [CrossRef]

321. Yuan, Z.L.; Guan, Y.J.; Chatterjee, D.; Chin, Y.E. Stat3 dimerization regulated by reversible acetylation of a single lysine residue. Science (80-) 2005, 307, 269-273. [CrossRef] [PubMed]

322. Gray, M.J.; Zhang, J.; Ellis, L.M.; Semenza, G.L.; Evans, D.B.; Watowich, S.S.; Gallick, G.E. HIF-1 $\alpha$, STAT3, CBP/p300 and Ref-1/APE are components of a transcriptional complex that regulates Src-dependent hypoxia-induced expression of VEGF in pancreatic and prostate carcinomas. Oncogene 2005, 24, 3110-3120. [CrossRef] [PubMed]

323. Debes, J.D.; Sebo, T.J.; Lohse, C.M.; Murphy, L.M.; Haugen, D.A.L.; Tindall, D.J. p300 in Prostate Cancer Proliferation and Progression. Cancer Res. 2003, 63, 7638-7640. [PubMed]

324. Debes, J.D.; Schmidt, L.J.; Huang, H.; Tindall, D.J. p300 mediates androgen-independent transactivation of the androgen receptor by interleukin. Cancer Res. 2002, 62, 5632-5636.

325. Fu, M.; Wang, C.; Reutens, A.T.; Wang, J.; Angeletti, R.H.; Siconolfi-Baez, L.; Ogryzko, V.; Avantaggiati, M.L.; Pestell, R.G. p300 and p300/cAMP-response element-binding protein-associated factor acetylate the androgen receptor at sites governing hormone-dependent transactivation. J. Biol. Chem. 2000, 275, 20853-20860. [CrossRef] [PubMed]

326. Kim, C.H.; Lee, D.H. KAT5 Negatively regulates the proliferation of prostate cancer LNCaP cells via the caspase 3-dependent apoptosis pathway. Anim. Cells Syst. 2019, 23, 253-259. [CrossRef]

327. Xie, X.; Xu, Z.; Wang, C.; Fang, C.; Zhao, J.; Xu, L.; Qian, X.; Dai, J.; Sun, F.; Xu, D.; et al. Tip60 is associated with resistance to X-ray irradiation in prostate cancer. FEBS Open Bio. 2018, 8, 271-278. [CrossRef]

328. Gao, C.; Bourke, E.; Scobie, M.; Famme, M.A.; Koolmeister, T.; Helleday, T.; Eriksson, L.A.; Lowndes, N.F.; Brown, J.A.L. Rational design and validation of a Tip60 histone acetyltransferase inhibitor. Sci. Rep. 2014, 4, 5372. [CrossRef]

329. Judes, G.; Rifaï, K.; Ngollo, M.; Daures, M.; Bignon, Y.J.; Penault-Llorca, F.; Bernard-Gallon, D. A bivalent role of TIP60 histone acetyl transferase in human cancer. Epigenomics 2015, 7, 1351-1363. [CrossRef]

330. Lee, M.T.; Leung, Y.K.; Chung, I.; Tarapore, P.; Ho, S.M. Estrogen receptor $\beta$ (ER $\beta 1$ ) transactivation is differentially modulated by the transcriptional coregulator Tip60 in a cis-acting element-dependent manner. J. Biol. Chem. 2013, 288, 25038-25052. [CrossRef]

331. He, W.; Zhang, M.G.; Wang, X.J.; Zhong, S.; Shao, Y.; Zhu, Y.; Shen, Z.J. KAT5 and KAT6B are in positive regulation on cell proliferation of prostate cancer through PI3K-AKT signaling. Int. J. Clin. Exp. Pathol. 2013, 6, 2864-2871. [PubMed]

332. Coffey, K.; Blackburn, T.J.; Cook, S.; Golding, B.T.; Griffin, R.J.; Hardcastle, I.R.; Hewitt, L.; Huberman, K.; McNeill, H.V.; Newell, D.R.; et al. Characterisation of a Tip60 Specific Inhibitor, NU9056, in Prostate Cancer. PLoS ONE 2012, 7, e45539. [CrossRef] [PubMed]

333. Shiota, M.; Yokomizo, A.; Masubuchi, D.; Tada, Y.; Inokuchi, J.; Eto, M.; Uchiumi, T.; Fujimoto, N.; Naito, S. Tip60 promotes prostate cancer cell proliferation by translocation of androgen receptor into the nucleus. Prostate 2010. [CrossRef] [PubMed]

334. Kim, J.H.; Kim, B.; Cai, L.; Choi, H.J.; Ohgi, K.A.; Tran, C.; Chen, C.; Chung, C.H.; Huber, O.; Rose, D.W.; et al. Transcriptional regulation of a metastasis suppressor gene by Tip60 and $\beta$-catenin complexes. Nature 2005. [CrossRef] [PubMed]

335. Halkidou, K.; Gnanapragasam, V.J.; Mehta, P.B.; Logan, I.R.; Brady, M.E.; Cook, S.; Leung, H.Y.; Neal, D.E.; Robson, C.N. Expression of Tip60, an androgen receptor coactivator, and its role in prostate cancer development. Oncogene 2003, 22, $2466-2477$. [CrossRef] 
336. Gaughan, L.; Logan, I.R.; Cook, S.; Neal, D.E.; Robson, C.N. Tip60 and histone deacetylase 1 regulate androgen receptor activity through changes to the acetylation status of the receptor. J. Biol. Chem. 2002, 277, 25904-25913. [CrossRef] [PubMed]

337. Kim, J.Y.; Yu, J.; Abdulkadir, S.A.; Chakravarti, D. KAT8 regulates androgen signaling in prostate cancer cells. Mol. Endocrinol. 2016, 30, 925-936. [CrossRef]

338. Jaganathan, A.; Chaurasia, P.; Xiao, G.Q.; Philizaire, M.; Lv, X.; Yao, S.; Burnstein, K.L.; Liu, D.P.; Levine, A.C.; Mujtaba, S. Coactivator MYST1 regulates nuclear factor- $\mathrm{kB}$ and androgen receptor functions during proliferation of prostate cancer cells. Mol. Endocrinol. 2014, 28, 872-885. [CrossRef]

339. Katoh, H.; Qin, Z.S.; Liu, R.; Wang, L.; Li, W.; Li, X.; Wu, L.; Du, Z.; Lyons, R.; Liu, C.G.; et al. FOXP3 orchestrates H4K16 acetylation and $\mathrm{H} 3 \mathrm{~K} 4$ trimethylation for activation of multiple genes by recruiting MOF and causing displacement of PLU-1. Mol. Cell 2011, 44, 770-784. [CrossRef]

340. Shankar, E.; Pandey, M.; Verma, S.; Abbas, A.; Candamo, M.; Kanwal, R.; Shukla, S.; MacLennan, G.T.; Gupta, S. Role of class I histone deacetylases in the regulation of maspin expression in prostate cancer. Mol. Carcinog. 2020, 59, 955-966. [CrossRef]

341. Ma, J.B.; Bai, J.Y.; Zhang, H.B.; Jia, J.; Shi, Q.; Yang, C.; Wang, X.; He, D.; Guo, P. KLF5 inhibits STAT3 activity and tumor metastasis in prostate cancer by suppressing IGF1 transcription cooperatively with HDAC. Cell Death Dis. 2020, 11, 466. [CrossRef]

342. Kim, N.H.; Kim, S.N.; Kim, Y.K. Involvement of HDAC1 in E-cadherin expression in prostate cancer cells; its implication for cell motility and invasion. Biochem. Biophys. Res. Commun. 2011, 404, 915-921. [CrossRef]

343. Gaughan, L.; Logan, I.R.; Neal, D.E.; Robson, C.N. Regulation of androgen receptor and histone deacetylase 1 by Mdm2-mediated ubiquitylation. Nucleic Acids Res. 2005, 33, 13-26. [CrossRef]

344. Welsbie, D.S.; Xu, J.; Chen, Y.; Borsu, L.; Scher, H.I.; Rosen, N.; Sawyers, C.L. Histone deacetylases are required for androgen receptor function in hormone-sensitive and castrate-resistant prostate cancer. Cancer Res. 2009, 69, 958-966. [CrossRef] [PubMed]

345. Yang, Y.; Tse, A.K.W.; Li, P.; Ma, Q.; Xiang, S.; Nicosia, S.V.; Seto, E.; Zhang, X.; Bai, W. Inhibition of androgen receptor activity by histone deacetylase 4 through receptor SUMOylation. Oncogene 2011, 30, 2207-2218. [CrossRef]

346. Ren, G.; Zhang, G.; Dong, Z.; Liu, Z.; Li, L.; Feng, Y.; Su, D.; Zhang, Y.; Huang, B.; Lu, J. Recruitment of HDAC4 by transcription factor YY1 represses HOXB13 to affect cell growth in AR-negative prostate cancers. Int. J. Biochem. Cell Biol. 2009, 41, $1094-1101$. [CrossRef] [PubMed]

347. Corno, C.; Arrighetti, N.; Ciusani, E.; Corna, E.; Carenini, N.; Zaffaroni, N.; Gatti, L.; Perego, P. Synergistic Interaction of Histone Deacetylase 6- and MEK-Inhibitors in Castration-Resistant Prostate Cancer Cells. Front. Cell Dev. Biol. 2020, 8, 610. [CrossRef] [PubMed]

348. Jiang, X.; Huang, Y.; Liang, X.; Jiang, F.; He, Y.; Li, T.; Xu, G.; Zhao, H.; Yang, W.; Jiang, G.; et al. Metastatic prostate cancerassociated P62 inhibits autophagy flux and promotes epithelial to mesenchymal transition by sustaining the level of HDAC6. Prostate 2018, 78, 426-434. [CrossRef]

349. Ai, J.; Wang, Y.; Dar, J.A.; Liu, J.; Liu, L.; Nelson, J.B.; Wang, Z. HDAC6 regulates androgen receptor hypersensitivity and nuclear localization via modulating Hsp90 acetylation in castration-resistant prostate cancer. Mol. Endocrinol. 2009, 23, $1963-1972$. [CrossRef]

350. Bakin, R.E.; Jung, M.O. Cytoplasmic sequestration of HDAC7 from mitochondrial and nuclear compartments upon initiation of apoptosis. J. Biol. Chem. 2004, 279, 51218-51225. [CrossRef]

351. Deubzer, H.E.; Schier, M.C.; Oehme, I.; Lodrini, M.; Haendler, B.; Sommer, A.; Witt, O. HDAC11 is a novel drug target in carcinomas. Int. J. Cancer 2012, 132, 2200-2208. [CrossRef]

352. Muscolini, M.; Castiello, L.; Palermo, E.; Zevini, A.; Ferrari, M.; Olagnier, D.; Hiscott, J. SIRT1 Modulates the Sensitivity of Prostate Cancer Cells to Vesicular Stomatitis Virus Oncolysis. J. Virol. 2019, 93. [CrossRef] [PubMed]

353. Yu, Y.; Zhang, Q.; Meng, Q.; Zong, C.; Liang, L.; Yang, X.; Lin, R.; Liu, Y.; Zhou, Y.; Zhang, H.; et al. Mesenchymal stem cells overexpressing Sirt1 inhibit prostate cancer growth by recruiting natural killer cells and macrophages. Oncotarget 2016, 7 , 71112-71122. [CrossRef] [PubMed]

354. Kumar, P.; Sharad, S.; Petrovics, G.; Mohamed, A.; Dobi, A.; Sreenath, T.L.; Srivastava, S.; Biswas, R. Loss of miR-449a in ERG-associated prostate cancer promotes the invasive phenotype by inducing SIRT1. Oncotarget 2016, 7, 22791-22806. [CrossRef] [PubMed]

355. Roth, M.; Wang, Z.; Chen, W.Y. SIRT1 and LSD1 competitively regulate KU70 functions in DNA repair and mutation acquisition in cancer cells. Oncotarget 2016, 7, 50195-50214. [CrossRef]

356. Cui, Y.; Li, J.; Zheng, F.; Ouyang, Y.; Chen, X.; Zhang, L.; Chen, Y.; Wang, L.; Mu, S.; Zhang, H. Effect of SIRT1 gene on epithelial-mesenchymal transition of human prostate cancer PC-3 cells. Med. Sci. Monit. 2016, 22, 380-386. [CrossRef]

357. Sun, L.; Kokura, K.; Izumi, V.; Koomen, J.M.; Seto, E.; Chen, J.; Fang, J. MPP 8 and SIRT 1 crosstalk in E-cadherin gene silencing and epithelial-mesenchymal transition. EMBO Rep. 2015, 16, 689-699. [CrossRef]

358. Baptista, T.; Graça, I.; Sousa, E.J.; Oliveira, A.I.; Costa, N.R.; Costa-Pinheiro, P.; Amado, F.; Henrique, R.; Jerónimo, C. Regulation of histone H2A.Z expression is mediated by sirtuin 1 in prostate cancer. Oncotarget 2013, 4, 1673-1685. [CrossRef]

359. Lovaas, J.D.; Zhu, L.; Chiao, C.Y.; Byles, V.; Faller, D.V.; Dai, Y. SIRT1 enhances matrix metalloproteinase-2 expression and tumor cell invasion in prostate cancer cells. Prostate 2013. [CrossRef]

360. Byles, V.; Zhu, L.; Lovaas, J.D.; Chmilewski, L.K.; Wang, J.; Faller, D.V.; Dai, Y. SIRT1 induces EMT by cooperating with EMT transcription factors and enhances prostate cancer cell migration and metastasis. Oncogene 2012, 31, 4619-4629. [CrossRef] 
361. Nakane, K.; Fujita, Y.; Terazawa, R.; Atsumi, Y.; Kato, T.; Nozawa, Y.; Deguchi, T.; Ito, M. Inhibition of cortactin and SIRT1 expression attenuates migration and invasion of prostate cancer DU145 cells. Int. J. Urol. 2012. [CrossRef]

362. Powell, M.J.; Casimiro, M.C.; Cordon-Cardo, C.; He, X.; Yeow, W.S.; Wang, C.; McCue, P.A.; McBurney, M.W.; Pestell, R.G. Disruption of a Sirt1-dependent autophagy checkpoint in the prostate results in prostatic intraepithelial neoplasia lesion formation. Cancer Res. 2011, 71, 964-975. [CrossRef]

363. Kang, H.; Suh, J.Y.; Jung, Y.S.; Jung, J.W.; Kim, M.K.; Chung, J.H. Peptide switch is essential for Sirt1 deacetylase activity. Mol. Cell 2011, 44, 203-213. [CrossRef]

364. Jung-Hynes, B.; Nihal, M.; Zhong, W.; Ahmad, N. Role of sirtuin histone deacetylase SIRT1 in prostate cancer: A target for prostate cancer management via its inhibition? J. Biol. Chem. 2009. [CrossRef] [PubMed]

365. Jung-Hynes, B.; Ahmad, N. Role of p53 in the anti-proliferative effects of Sirt1 inhibition in prostate cancer cells. Cell Cycle 2009, 8, 1478-1483. [CrossRef]

366. Kojima, K.; Ohhashi, R.; Fujita, Y.; Hamada, N.; Akao, Y.; Nozawa, Y.; Deguchi, T.; Ito, M. A role for SIRT1 in cell growth and chemoresistance in prostate cancer PC3 and DU145 cells. Biochem. Biophys. Res. Commun. 2008, 373, 423-428. [CrossRef] [PubMed]

367. Dai, Y.; Ngo, D.; Forman, L.W.; Qin, D.C.; Jacob, J.; Faller, D.V. Sirtuin 1 is required for antagonist-induced transcriptional repression of androgen-responsive genes by the androgen receptor. Mol. Endocrinol. 2007, 21, 1807-1821. [CrossRef] [PubMed]

368. Fu, M.; Liu, M.; Sauve, A.A.; Jiao, X.; Zhang, X.; Wu, X.; Powell, M.J.; Yang, T.; Gu, W.; Avantaggiati, M.L.; et al. Hormonal Control of Androgen Receptor Function through SIRT1. Mol. Cell. Biol. 2006, 26, 8122-8135. [CrossRef]

369. Yang, Y.; Hou, H.; Haller, E.M.; Nicosia, S.V.; Bai, W. Suppression of FOXO1 activity by FHL2 through SIRT1-mediated deacetylation. EMBO J. 2005, 24, 1021-1032. [CrossRef] [PubMed]

370. Damodaran, S.; Damaschke, N.; Gawdzik, J.; Yang, B.; Shi, C.; Allen, G.O.; Huang, W.; Denu, J.; Jarrard, D. Dysregulation of Sirtuin 2 (SIRT2) and histone H3K18 acetylation pathways associates with adverse prostate cancer outcomes. BMC Cancer 2017, 17, 874. [CrossRef]

371. Sawant Dessai, A.; Palestino Dominguez, M.; Chen, U.-I.; Hasper, J.; Prechtl, C.; Yu, C.; Katsuta, E.; Dai, T.; Zhu, B.; Jung, S.Y.; et al. Transcriptional repression of SIRT3 potentiates mitochondrial aconitase activation to drive aggressive prostate cancer to the bone. Cancer Res. 2020. [CrossRef]

372. Fu, W.; Li, H.; Fu, H.; Zhao, S.; Shi, W.; Sun, M.; Li, Y. The SIRT3 and SIRT6 Promote Prostate Cancer Progression by Inhibiting Necroptosis-Mediated Innate Immune Response. J. Immunol. Res. 2020, 2020, 1-12. [CrossRef]

373. Li, R.; Quan, Y.; Xia, W. SIRT3 inhibits prostate cancer metastasis through regulation of FOXO3A by suppressing Wnt/ $\beta$-catenin pathway. Exp. Cell Res. 2018, 364, 143-151. [CrossRef] [PubMed]

374. Quan, Y.; Wang, N.; Chen, Q.; Xu, J.; Cheng, W.; Di, M.; Xia, W.; Gao, W.Q. SIRT3 inhibits prostate cancer by destabilizing oncoprotein c-MYC through regulation of the PI3K/Akt pathway. Oncotarget 2015, 6, 26494-26507. [CrossRef]

375. Li, T.; Li, Y.; Liu, T.; Hu, B.; Li, J.; Liu, C.; Liu, T.; Li, F. Mitochondrial PAK6 inhibits prostate cancer cell apoptosis via the PAK6-SIRT4-ANT2 complex. Theranostics 2020, 10, 2571-2586. [CrossRef]

376. Guan, J.; Jiang, X.; Gai, J.; Sun, X.; Zhao, J.; Li, J.; Li, Y.; Cheng, M.; Du, T.; Fu, L.; et al. Sirtuin 5 regulates the proliferation, invasion and migration of prostate cancer cells through acetyl-CoA acetyltransferase. J. Cell. Mol. Med. 2020, 24, 14039-14049. [CrossRef] [PubMed]

377. Wu, M.; Seto, E.; Zhang, J. E2F1 enhances glycolysis through suppressing Sirt6 transcription in cancer cells. Oncotarget 2015, 6, 11252-11263. [CrossRef] [PubMed]

378. Liu, Y.; Xie, Q.R.; Wang, B.; Shao, J.; Zhang, T.; Liu, T.; Huang, G.; Xia, W. Inhibition of SIRT6 in prostate cancer reduces cell viability and increases sensitivity to chemotherapeutics. Protein Cell 2013, 4, 702-710. [CrossRef]

379. Ding, M.; Jiang, C.Y.; Zhang, Y.; Zhao, J.; Han, B.M.; Xia, S.J. SIRT7 depletion inhibits cell proliferation and androgen-induced autophagy by suppressing the AR signaling in prostate cancer. J. Exp. Clin. Cancer Res. 2020, 39, 1-18. [CrossRef]

380. Haider, R.; Massa, F.; Kaminski, L.; Clavel, S.; Djabari, Z.; Robert, G.; Laurent, K.; Michiels, J.F.; Durand, M.; Ricci, J.E.; et al. Sirtuin 7: A new marker of aggressiveness in prostate cancer. Oncotarget 2017, 8, 77309-77316. [CrossRef]

381. Malik, S.; Villanova, L.; Tanaka, S.; Aonuma, M.; Roy, N.; Berber, E.; Pollack, J.R.; Michishita-Kioi, E.; Chua, K.F. SIRT7 inactivation reverses metastatic phenotypes in epithelial and mesenchymal tumors. Sci. Rep. 2015, 5, 9841. [CrossRef] [PubMed]

382. Morton, D.J.; Patel, D.; Joshi, J.; Hunt, A.; Knowell, A.E.; Chaudhary, J. ID4 regulates transcriptional activity of wild type and mutant p53 via K373 acetylation. Oncotarget 2016, 8, 2536-2549. [CrossRef] [PubMed]

383. Roy, S.; Tenniswood, M. Site-specific acetylation of p53 directs selective transcription complex assembly. J. Biol. Chem. 2007, 282, 4765-4771. [CrossRef] [PubMed]

384. Kai, L.; Samuel, S.K.; Levenson, A.S. Resveratrol enhances p53 acetylation and apoptosis in prostate cancer by inhibiting MTA1/NuRD complex. Int. J. Cancer 2010, 126, 1538-1548. [CrossRef]

385. Dhar, S.; Kumar, A.; Li, K.; Tzivion, G.; Levenson, A.S. Resveratrol regulates PTEN/Akt pathway through inhibition of MTA1/HDAC unit of the NuRD complex in prostate cancer. Biochim. Biophys. Acta-Mol. Cell Res. 2015, 1853, 265-275. [CrossRef]

386. Li, J.; Zhang, B.; Liu, M.; Fu, X.; Ci, X.; Jun, A.; Fu, C.; Dong, G.; Wu, R.; Zhang, Z.; et al. Klf5 is crucial for androgen-ar signaling to transactivate genes and promote cell proliferation in prostate cancer cells. Cancers 2020, 12, 748. [CrossRef] [PubMed]

387. Liu, X.; Gomez-Pinillos, A.; Loder, C.; Carrillo-De Santa Pau, E.; Qiao, R.; Unger, P.D.; Kurek, R.; Oddoux, C.; Melamed, J.; Gallagher, R.E.; et al. KLF6 loss of function in human prostate cancer progression is implicated in resistance to androgen deprivation. Am. J. Pathol. 2012, 181, 1007-1016. [CrossRef] 
388. Zhang, B.; Ci, X.; Tao, R.; Ni, J.J.; Xuan, X.; King, J.L.; Xia, S.; Li, Y.; Frierson, H.F.; Lee, D.K.; et al. Klf5 acetylation regulates luminal differentiation of basal progenitors in prostate development and regeneration. Nat. Commun. 2020, 11, 1-16. [CrossRef] [PubMed]

389. Li, Y.; Zhang, B.; Xiang, L.; Xia, S.; Kucuk, O.; Deng, X.; Boise, L.H.; Dong, J.T. TGF- $\beta$ causes docetaxel resistance in prostate cancer via the induction of Bcl-2 by acetylated KLF5 and protein stabilization. Theranostics 2020, 10, 7656-7670. [CrossRef] [PubMed]

390. Li, X.; Zhang, B.; Wu, Q.; Ci, X.; Zhao, R.; Zhang, Z.; Xia, S.; Su, D.; Chen, J.; Ma, G.; et al. Interruption of KLF5 acetylation converts its function from tumor suppressor to tumor promoter in prostate cancer cells. Int. J. Cancer 2015. [CrossRef] [PubMed]

391. Xing, C.; Fu, X.; Sun, X.; Guo, P.; Li, M.; Dong, J.T. Different Expression Patterns and Functions of Acetylated and Unacetylated Klf5 in the Proliferation and Differentiation of Prostatic Epithelial Cells. PLoS ONE 2013, 8, e65538. [CrossRef]

392. Li, D.; Yea, S.; Dolios, G.; Martignetti, J.A.; Narla, G.; Wang, R.; Walsh, M.J.; Friedman, S.L. Regulation of Krüppel-like Factor 6 Tumor Suppressor Activity by Acetylation. Cancer Res. 2005, 65, 9216-9225. [CrossRef]

393. Jiang, H.; Zhang, X.; Chen, X.; Aramsangtienchai, P.; Tong, Z.; Lin, H. Protein Lipidation: Occurrence, Mechanisms, Biological Functions, and Enabling Technologies. Chem. Rev. 2018, 118, 919-988. [CrossRef]

394. De Piano, M.; Manuelli, V.; Zadra, G.; Otte, J.; Edqvist, P.H.D.; Pontén, F.; Nowinski, S.; Niaouris, A.; Grigoriadis, A.; Loda, M.; et al. Lipogenic signalling modulates prostate cancer cell adhesion and migration via modification of Rho GTPases. Oncogene 2020, 39, 3666-3679. [CrossRef]

395. De Piano, M.; Manuelli, V.; Zadra, G.; Loda, M.; Muir, G.; Chandra, A.; Morris, J.; Van Hemelrijck, M.; Wells, C.M. Exploring a role for fatty acid synthase in prostate cancer cell migration. Small GTPases 2020, 1-8. [CrossRef] [PubMed]

396. Sabbisetti, V.; Di Napoli, A.; Seeley, A.; Amato, A.M.; O’Regan, E.; Ghebremichael, M.; Loda, M.; Signoretti, S. p63 promotes cell survival through fatty acid synthase. PLoS ONE 2009, 4, e5877. [CrossRef] [PubMed]

397. Little, J.L.; Wheeler, F.B.; Fels, D.R.; Koumenis, C.; Kridel, S.J. Inhibition of fatty acid synthase induces endoplasmic reticulum stress in tumor cells. Cancer Res. 2007, 67, 1262-1269. [CrossRef] [PubMed]

398. Coleman, D.T.; Bigelow, R.; Cardelli, J.A. Inhibition of fatty acid synthase by luteolin post-transcriptionally down-regulates c-Met expression independent of proteosomal/lysosomal degradation. Mol. Cancer Ther. 2009, 8, 214-224. [CrossRef]

399. Han, C.; Yu, G.; Mao, Y.; Song, S.; Li, L.; Zhou, L.; Wang, Z.; Liu, Y.; Li, M.; Xu, B. LPCAT1 enhances castration resistant prostate cancer progression via increased mRNA synthesis and PAF production. PLoS ONE 2020, 15, e0240801. [CrossRef] [PubMed]

400. Seshacharyulu, P.; Rachagani, S.; Muniyan, S.; Siddiqui, J.A.; Cruz, E.; Sharma, S.; Krishnan, R.; Killips, B.J.; Sheinin, Y.; Lele, S.M.; et al. FDPS cooperates with PTEN loss to promote prostate cancer progression through modulation of small GTPases/AKT axis. Oncogene 2019, 38, 5265-5280. [CrossRef]

401. Virtanen, S.S.; Sandholm, J.; Yegutkin, G.; Kalervo Väänänen, H.; Härkönen, P.L. Inhibition of GGTase-I and FTase disrupts cytoskeletal organization of human PC-3 prostate cancer cells. Cell Biol. Int. 2010, 34, 815-826. [CrossRef]

402. Weissenrieder, J.S.; Reilly, J.E.; Neighbors, J.D.; Hohl, R.J. Inhibiting geranylgeranyl diphosphate synthesis reduces nuclear androgen receptor signaling and neuroendocrine differentiation in prostate cancer cell models. Prostate 2019, 79, 21-30. [CrossRef] [PubMed]

403. Reilly, J.E.; Neighbors, J.D.; Hohl, R.J. Targeting protein geranylgeranylation slows tumor development in a murine model of prostate cancer metastasis. Cancer Biol. Ther. 2017. [CrossRef]

404. Reilly, J.E.; Neighbors, J.D.; Tong, H.; Henry, M.D.; Hohl, R.J. Targeting geranylgeranylation reduces adrenal gland tumor burden in a murine model of prostate cancer metastasis. Clin. Exp. Metastasis 2015, 32, 555-566. [CrossRef]

405. Moon, H.; Hill, M.M.; Roberts, M.J.; Gardiner, R.A.; Brown, A.J. Statins: Protectors or pretenders in prostate cancer? Trends Endocrinol. Metab. 2014, 25, 188-196. [CrossRef] [PubMed]

406. Zheng, X.; Cui, X.X.; Gao, Z.; Zhao, Y.; Lin, Y.; Shih, W.J.; Huang, M.T.; Liu, Y.; Rabson, A.; Reddy, B.; et al. Atorvastatin and celecoxib in combination inhibits the progression of androgen-dependent LNCaP xenograft prostate tumors to androgen independence. Cancer Prev. Res. 2010, 3, 114-124. [CrossRef] [PubMed]

407. Wang, C.; Tao, W.; Wang, Y.; Bikow, J.; Lu, B.; Keating, A.; Verma, S.; Parker, T.G.; Han, R.; Wen, X.Y. Rosuvastatin, identified from a zebrafish chemical genetic screen for antiangiogenic compounds, suppresses the growth of prostate cancer. Eur. Urol. 2010, 58, 418-426. [CrossRef] [PubMed]

408. Zhuang, L.; Kim, J.; Adam, R.M.; Solomon, K.R.; Freeman, M.R. Cholesterol targeting alters lipid raft composition and cell survival in prostate cancer cells and xenografts. J. Clin. Investig. 2005, 115, 959-968. [CrossRef]

409. Yokomizo, A.; Shiota, M.; Kashiwagi, E.; Kuroiwa, K.; Tatsugami, K.; Inokuchi, J.; Takeuchi, A.; Naito, S. Statins reduce the androgen sensitivity and cell proliferation by decreasing the androgen receptor protein in prostate cancer cells. Prostate 2011. [CrossRef]

410. Hoque, A.; Chen, H.; Xu, X.C. Statin induces apoptosis and cell growth arrest in prostate cancer cells. Cancer Epidemiol. Biomarkers Prev. 2008, 17, 88-94. [CrossRef]

411. Parikh, A.; Childress, C.; Deitrick, K.; Lin, Q.; Rukstalis, D.; Yang, W. Statin-induced autophagy by inhibition of geranylgeranyl biosynthesis in prostate cancer PC3 cells. Prostate 2010, 70, 971-981. [CrossRef] [PubMed]

412. Cai, H.; Smith, D.A.; Memarzadeh, S.; Lowell, C.A.; Cooper, J.A.; Witte, O.N. Differential transformation capacity of Src family kinases during the initiation of prostate cancer. Proc. Natl. Acad. Sci. USA 2011, 108, 6579-6584. [CrossRef] [PubMed] 
413. Li, Q.; Ingram, L.; Kim, S.; Beharry, Z.; Cooper, J.A.; Cai, H. Paracrine Fibroblast Growth Factor Initiates Oncogenic Synergy with Epithelial FGFR/Src Transformation in Prostate Tumor Progression. Neoplasia 2018, 20, 233-243. [CrossRef]

414. Kim, S.; Yang, X.; Li, Q.; Wu, M.; Costyn, L.; Beharry, Z.; Bartlett, M.G.; Cai, H. Myristoylation of Src kinase mediates Src-induced and high-fat diet-accelerated prostate tumor progression in mice. J. Biol. Chem. 2017, 292, 18422-18433. [CrossRef] [PubMed]

415. Kim, S.; Alsaidan, O.A.; Goodwin, O.; Li, Q.; Sulejmani, E.; Han, Z.; Bai, A.; Albers, T.; Beharry, Z.; Zheng, Y.G.; et al. Blocking myristoylation of Src inhibits its kinase activity and suppresses prostate cancer progression. Cancer Res. 2017, 77, 6950-6962. [CrossRef]

416. Adam, R.M.; Mukhopadhyay, N.K.; Kim, J.; Di Vizio, D.; Cinar, B.; Boucher, K.; Solomon, K.R.; Freeman, M.R. Cholesterol sensitivity of endogenous and myristoylated Akt. Cancer Res. 2007, 67, 6238-6246. [CrossRef]

417. Razandi, M.; Pedram, A.; Levin, E.R. Heat Shock Protein 27 Is Required for Sex Steroid Receptor Trafficking to and Functioning at the Plasma Membrane. Mol. Cell. Biol. 2010, 30, 3249-3261. [CrossRef]

418. Zhou, B.; Liu, L.; Reddivari, M.; Zhang, X.A. The palmitoylation of metastasis suppressor KAI1/CD82 is important for its motilityand invasiveness-inhibitory activity. Cancer Res. 2004, 64, 7455-7463. [CrossRef]

419. Li, Q.; Alsaidan, O.A.; Ma, Y.; Kim, S.; Liu, J.; Albers, T.; Liu, K.; Beharry, Z.; Zhao, S.; Wang, F.; et al. Pharmacologically targeting the myristoylation of the scaffold protein FRS2 inhibits FGF/FGFR-mediated oncogenic signaling and tumor progression. J. Biol. Chem. 2018, 293, 6434-6448. [CrossRef] [PubMed]

420. Pottier, C.; Fresnais, M.; Gilon, M.; Jérusalem, G.; Longuespée, R.; Sounni, N.E. Tyrosine kinase inhibitors in cancer: Breakthrough and challenges of targeted therapy. Cancers 2020, 12, 731. [CrossRef]

421. Ojemuyiwa, M.A.; Madan, R.A.; Dahut, W.L. Tyrosine kinase inhibitors in the treatment of prostate cancer: Taking the next step in clinical development. Expert Opin. Emerg. Drugs 2014, 19, 459-470. [CrossRef] [PubMed]

422. De Bono, J.S.; De Giorgi, U.; Rodrigues, D.N.; Massard, C.; Bracarda, S.; Font, A.; Arija, J.A.A.; Shih, K.C.; Radavoi, G.D.; Xu, N.; et al. Randomized phase II study evaluating AKT blockade with ipatasertib, in combination with abiraterone, in patients with metastatic prostate cancer with and without PTEN loss. Clin. Cancer Res. 2019, 25, 928-936. [CrossRef]

423. Ramroop, J.R.; Stein, M.N.; Drake, J.M. Impact of phosphoproteomics in the era of precision medicine for prostate cancer. Front. Oncol. 2018, 8, 28. [CrossRef]

424. Yang, W.; Freeman, M.R.; Kyprianou, N. Personalization of prostate cancer therapy through phosphoproteomics. Nat. Rev. Urol. 2018, 15, 483-497. [CrossRef]

425. Yamada, Y.; Beltran, H. Clinical and Biological Features of Neuroendocrine Prostate Cancer. Curr. Oncol. Rep. 2021, 23, 1-10. [CrossRef]

426. Beltran, H.; Oromendia, C.; Danila, D.C.; Montgomery, B.; Hoimes, C.; Szmulewitz, R.Z.; Vaishampayan, U.; Armstrong, A.J.; Stein, M.; Pinski, J.; et al. A phase II trial of the aurora kinase a inhibitor alisertib for patients with castration-resistant and neuroendocrine prostate cancer: Efficacy and biomarkers. Clin. Cancer Res. 2019, 25, 43-51. [CrossRef]

427. VanDeusen, H.R.; Ramroop, J.R.; Morel, K.L.; Bae, S.Y.; Sheahan, A.V.; Sychev, Z.; Lau, N.A.; Cheng, L.C.; Tan, V.M.; Li, Z.; et al. Targeting RET Kinase in Neuroendocrine Prostate Cancer. Mol. Cancer Res. 2020, 18, 1176-1188. [CrossRef]

428. Mateo, J.; McKay, R.; Abida, W.; Aggarwal, R.; Alumkal, J.; Alva, A.; Feng, F.; Gao, X.; Graff, J.; Hussain, M.; et al. Accelerating precision medicine in metastatic prostate cancer. Nat. Cancer 2020, 1, 1041-1053. [CrossRef]

429. Ku, S.Y.; Gleave, M.E.; Beltran, H. Towards precision oncology in advanced prostate cancer. Nat. Rev. Urol. 2019, 16, 645-654 [CrossRef] [PubMed]

430. Haven, N.; Meeting, A. Proof-of-Concept with PROTACs in Prostate Cancer. Cancer Discov. 2020, 10, 1084. [CrossRef]

431. van der Steen, T.; Tindall, D.J.; Huang, H. Posttranslational modification of the androgen receptor in prostate cancer. Int. J. Mol. Sci. 2013, 14, 14833-14859. [CrossRef] [PubMed]

432. Coffey, K.; Robson, C.N. Regulation of the androgen receptor by post-translational modifications. J. Endocrinol. 2012, 215, 221-237. [CrossRef]

433. Kumar, A.; Zhang, K.Y.J. Advances in the development of SUMO specific protease (SENP) inhibitors. Comput. Struct. Biotechnol. J. 2015, 13, 204-211. [CrossRef]

434. Yang, Y.; Xia, Z.; Wang, X.; Zhao, X.; Sheng, Z.; Ye, Y.; He, G.; Zhou, L.; Zhu, H.; Xu, N.; et al. Small-molecule inhibitors targeting protein sumoylation as novel anticancer compounds. Mol. Pharmacol. 2018, 94, 885-894. [CrossRef] [PubMed]

435. Rana, Z.; Diermeier, S.; Hanif, M.; Rosengren, R.J. Understanding failure and improving treatment using HDAC inhibitors for prostate cancer. Biomedicines 2020, 8, 22. [CrossRef]

436. He, Z.X.; Wei, B.F.; Zhang, X.; Gong, Y.P.; Ma, L.Y.; Zhao, W. Current development of CBP/p300 inhibitors in the last decade. Eur. J. Med. Chem. 2021, 209, 112861. [CrossRef] [PubMed]

437. Costa, A.F.; Campos, D.; Reis, C.A.; Gomes, C. Targeting Glycosylation: A New Road for Cancer Drug Discovery. Trends Cancer 2020, 6, 757-766. [CrossRef]

438. Leslie, N.R.; Kriplani, N.; Hermida, M.A.; Alvarez-Garcia, V.; Wise, H.M. The PTEN protein: Cellular localization and posttranslational regulation. Biochem. Soc. Trans. 2016, 44, 273-278. [CrossRef]

439. Cocchiola, R.; Rubini, E.; Altieri, F.; Chichiarelli, S.; Paglia, G.; Romaniello, D.; Carissimi, S.; Giorgi, A.; Giamogante, F.; Macone, A.; et al. STAT3 post-translational modifications drive cellular signaling pathways in prostate cancer cells. Int. J. Mol. Sci. 2019, 20, 1815. [CrossRef] 
440. Lin, W.Y.; Luo, J.; Sun, Y.; Lin, C.Y.; Li, G.; Niu, Y.; Chang, C. ASC-J9 ${ }^{\circledR}$ suppresses prostate cancer cell invasion via altering the sumoylation-phosphorylation of STAT3. Cancer Lett. 2018, 425, 21-30. [CrossRef]

441. Padmanabhan, A.; Rao, V.; De Marzo, A.M.; Bieberich, C.J. Regulating NKX3.1 stability and function: Post-translational modifications and structural determinants. Prostate 2016, 76, 523-533. [CrossRef] [PubMed] 